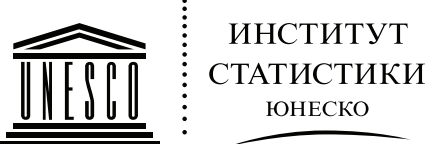

Объединеннганизация

вопросам образования.

науки и культуры

Международная стандартная классификация образования
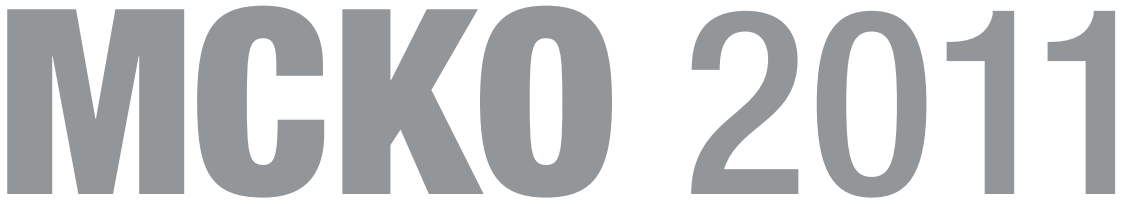



\section{Международная стандартная классификация образования MCKO 2011}

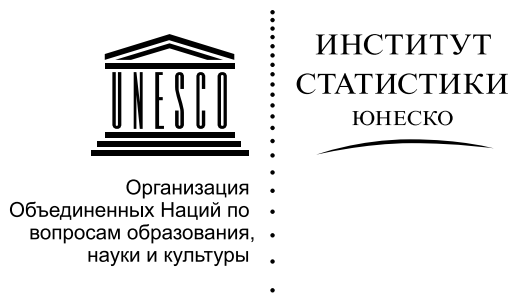




\section{ЮHECKO}

Устав Организации Объединенных Наций по вопросам образования, науки и культуры (ЮНЕСКО) был принят на Лондонской конференции 20 странами в ноябре 1945 г. и вступил в силу 4 ноября 1946 г. Членами организации в настоящее время являются 195 стран-участниц и 8 ассоциированных членов.

Главная задача ЮНЕСКО заключается в том, чтобы содействовать укреплению мира и безопасности путем расширения сотрудничества народов в области образования, науки и культуры в интересах обеспечения всеобщего уважения, справедливости, законности и прав человека, а также основных свобод, провозглашенных в Уставе Организации Объединенных Наций, для всех народов без различия расы, пола, языка и религии.

Для решения поставленных задач ЮНЕСКО осуществляет пять следующих функций: 1) перспективные исследования в области образования, науки, культуры и коммуникации, посвященные миру будущего; 2) продвижение, передача и совместное использование научных знаний путем проведения научных исследований, подготовки и учебной деятельности; 3) разработка стандартов с целью подготовки и принятия международных правовых актов и регламентирующих рекомендаций; 4) услуги экспертов в рамках технического сотрудничества со странами-участницами с целью разработки их политики и проектов; и 5) обмен специализированной информацией.

Штаб-квартира ЮНЕСКО находится в Париже, Франция.

\section{Институт статистики ЮНЕСКО}

Институт статистики ЮНЕСКО (ИСЮ) является статистическим органом Организации Объединенных Наций по вопросам образования, науки и культуры, в котором хранится информация в области образования, науки и технологии, культуры и коммуникации со всего мира, имеющаяся в распоряжении $\mathrm{OOH}$.

Институт статистики был создан в июле 1999 г. в целях совершенствования статистической программы ЮНЕСКО для сбора, обработки и предоставления своевременных и точных статистических данных, необходимых для разработки политики в современных быстро меняющихся и становящихся все более сложными условиях.

ИСЮ находится в Монреале, Канада.

Издано в 2013 г.

Институт Статистики ЮНЕСКО

P.O. Box 6128, Succursale Centre-Ville

Montreal, Quebec H3C 3J7

Canada

Тел.: (1 514) 343-6880

Адрес электронной почты: uis.publications@unesco.org

http://www.uis.unesco.org

ISBN 978-92-9189-132-0

Ref: UIS/2012/INS/10

Дизайн: JCNicholls/www.jcnicholls.com

CUNESCO-UIS 2013 
В связи с тем, что национальные системы образования разнообразны по своей структуре и по содержанию образовательных программ, сравнивать достижения различных стран и отслеживать их продвижение к целям на национальном и международном уровнях может быть непросто. Чтобы понять и верно интерпретировать аспекты и процессы образовательных систем на мировом уровне, особенно важно обеспечить сопоставимость данных. Она может быть достигнута посредством применения Международной стандартной классификации образования (МСКО) - концептуального документа, предназначенного для классификации и представления сопоставимых на международном уровне статистических данных.

Классификация МСКО 2011 была принята на 36-й сессии Генеральной конференции ЮНЕСКО в ноябре 2011 года. Изначально разработанная ЮНЕСКО в 1970-х годах и впервые пересмотренная в 1997 году, классификация МСКО служит инструментом для сбора и представления статистических данных в области образования, как на национальном, так и на международном уровне. Данный документ периодически обновлялся для более точного отражения нововведений в образовательных системах по всему миру.

В МСКО 2011 содержатся усовершенствованные определения типов образования и уточняется их применение в контексте МСКО. К существующей классификации уровней образования были добавлены новые категории, в связи с развитием системы образования детей младшего возраста и реструктурированием системы третичного образования. Также в классификации присутствуют следующие нововведения:

і) введение образовательных квалификаций в качестве статистической единицы, соответствующей определенной образовательной программе;

ii) трёхзначная схема кодирования, применяемая для обозначения уровней образовательных программ и уровней полученного образования;

iii) раздел, посвящённый управлению МСКО; и

iv) расширенный глоссарий.

Эти усовершенствования были предложены международной технической консультативной группой, в которую вошли международные эксперты в области образования и статистики, в том числе заинтересованные международные организации и организации-партнёры, такие как Евростат и Организация экономического сотрудничества и развития (ОЭСР). В процессе основательного пересмотра классификации состоялись серия совещаний региональных экспертов и официальная глобальная консультация под руководством Института Статистики ЮНЕСКО (ИСЮ), принять участие в которой были приглашены все страны-члены ЮНЕСКО.

Программы сбора данных ИСЮ и ЮНЕСКО-ОЭСР-Евростат (ЮОЕ) будут приведены в соответствие с новыми стандартами. Страны-члены ЮНЕСКО начнут применять МСКО 2011 в своей статистической отчётности в области образования с 2014 года.

МСКО 2011 внесёт свой вклад в создание ещё более надёжной и сопоставимой на мировом уровне статистики в области образования, отражая непрерывную эволюцию систем образования по всему миру.

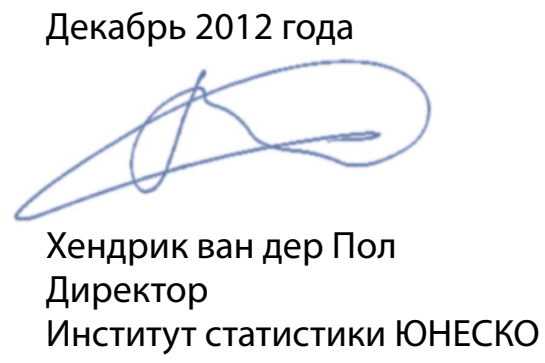





\section{СОДЕРЖАНИЕ}

Глава 1.

Что такое MCKO?

Глава 2.

Единица классификации.

7

Глава 3. Программы, охватывающие несколько уровней МСКО, последовательные программы в рамках одного уровня и модульные программы.

Глава 4.

Глава 5. Сквозные классификационные переменные 13

Глава 6.

Типы данных . 19

Глава 7.

Схемы кодирования.

Глава 8.

Управление

Глава 9.

Уровни МСКО

Уровень 0 - образование детей младшего возраста 26

Уровень 1 - начальное образование. 30

Уровень 2 - первый этап среднего образования. 33

Уровень 3 - второй этап среднего образования.. 38

Уровень 4 - послесреднее нетретичное образование. 43

Третичное образование 46

Уровень 5 - короткий цикл третичного образования 48

Уровень 6 - бакалавриат или его эквивалент. 51

Уровень 7 - магистратура или её эквивалент 55

Уровень 8 - докторантура или её эквивалент. 59

Глава 10. Соответствие уровней МСКО 2011 и МСКО 1997. 62

Приложение I. Возможные пути получения образования в соответствии с МСКО 2011 .68

Приложение II. Система кодирования образовательных программ 69

Приложение III. Система кодирования уровня полученного образования 72

Приложение IV. Расширенные группы и области образования. 74

Приложение V.Неформальное образование МСКО: дополнения. .77

Приложение VI. Глоссарий .79 


\section{ГЛАВА 1 ЧТО ТАКОЕ MСKO?}

1. Международная стандартная классификация образования (МСКО) является частью Международной системы социальных и экономических классификаций Организации Объединенных Наций, применяемых в статистике с целью сбора и анализа сопоставимых на международном уровне данных. МСКО - это классификация, являющаяся руководством для упорядочения образовательных программ и соответствующих квалификаций по уровням и областям образования. МСКО - это результат международного соглашения и документ, официально утверждённый странамиучастницами на Генеральной конференции ЮНЕСКО.

2. МСКО является основой для классификации образовательной деятельности, определенной в программах и итоговых квалификациях в соответствии с согласованными на международном уровне категориями. Поэтому основные положения и определения МСКО предназначены для международного применения и охвата всего спектра систем образования.

3. МСКО классифицирует образовательные программы по их содержанию с использованием двух основных сквозных классификационных переменных: уровней образования (см. главу 9) и областей образования (см. приложение 4). В МСКО 2011 представлен переработанный вариант уровней образования МСКО 1997 и соответствующая классификация уровней полученного образования на основе признанных образовательных квалификаций.

4. Информация, подготовленная на основе МСКО, может быть использована для сбора статистических данных, касающихся различных аспектов образования, которые представляют интерес для лиц, принимающих решения, и других лиц, использующих данные международной статистики образования. Эти аспекты включают данные по поступившим студентам, посещаемости, человеческим и финансовым ресурсам в образовании, уровню полученного населением образования.

5. Применение МСКО облегчает преобразование подробных национальных статистических данных об участниках, органах образования и спонсорах, собранных на основе национальных положений и определений, в совокупные категории, сопоставимые и интерпретируемые в международном масштабе.

6. Сбор данных статистики по образованию, осуществляемый в соответствии с МСКО, может быть основан на различных источниках, таких как административные документы, индивидуальные опросы, опрос домашних хозяйств, и на совокупности макроэкономических статистических данных. Рекомендации по применению МСКО 2011 в статистических источниках будут включены в руководство и другие материалы (см. главу 8).

7. МСКО 2011 состоит из трех компонентов: (i) согласованных на международном уровне положений и определений; (ii) системы классификации; и (iii) классификации национальных образовательных программ в соответствии с МСКО и соответствующих квалификаций в странах мира.

8. Классификация национальных образовательных программ в соответствии с МСКО является основным инструментом для систематизации информации по национальным системам образования, образовательным программам и соответствующим квалификациям, применяемых для сопоставления данных об уровнях МСКО и помощи в их интерпретации на международном уровне.

9. Классификация национальных образовательных программ в соответствии с МСКО обеспечивает прозрачность процесса кодирования национальных образовательных программ и соответствующих квалификаций в сопоставимые категории для их применения в международной статистике посредством связи критериев классификации с характеристиками образовательных программ и соответствующих квалификаций. 
10. Исходной единицей классификации МСКО является национальная (и субнациональная) образовательная программа и соответствующие признанные образовательные квалификации.

11. В МСКО образовательная программа определяется как единый комплекс или последовательность видов образовательной деятельности или коммуникации, спланированной и организованной для достижения заранее поставленных целей обучения или конкретных образовательных задач в течение определённого периода времени. Цели заключаются в совершенствовании знаний, навыков и компетенций в рамках личного, гражданского, общественного и/или производственного контекста. Цели обучения, как правило, связаны с подготовкой к обучению на более высоком уровне, овладением профессией или рядом профессий, а также, могут быть направлены на развитие личности или на проведение досуга. Общей характеристикой образовательной программы является то, что, по достижении целей обучения или после выполнения образовательных задач, выдается документ, подтверждающий успешное ее завершение.

Ключевые компоненты вышеупомянутой формулировки понимаются следующим образом:

12. ОБРАЗОВАТЕЛЬНАЯ ДЕЯТЕЛЬНОСТЬ: целенаправленная деятельность, предполагающая определенную форму коммуникации, нацеленной на обучение.

13. КОММУНИКАЦИЯ: взаимодействие двух или нескольких лиц или неодушевленного посредника и людей, включенных в процесс передачи информации (сообщений, идей, знания, принципов и т.д.). Коммуникация может быть вербальной и невербальной, непосредственной/личной, опосредованной/на расстоянии и может осуществляться посредством привлечения разнообразных средств и каналов общения.

14. ОБУЧЕНИЕ: индивидуальное получение знаний или модификация информации, знаний, понимания, мироощущений, ценностных установок, навыков, компетенций или поведения на основе опыта, практики, обучения или преподавания.

15. ОРГАНИЗОВАННАЯ: структурно или в определенной последовательности спланированная для достижения явно или неявно выраженных целей. Предполагается наличие учреждения-поставщика (лицо, группа лиц или организация), создающего условия для обучения и применения методов обучения, в рамках которых осуществляется коммуникация. Как правило, обучение предполагает наличие преподавателя или наставника, направляющего коммуникацию, знания и навыки на учебный процесс. Метод обучения может быть опосредованным, например, посредством радио, телевидения, компьютерного оборудования, фильмов, записей, интернета и других коммуникационных технологий.

16. ЦЕЛЕНАПРАВЛЕННЫЙ: учебный процесс характеризуется продолжительностью и непрерывностью.

17. В национальном контексте может быть дано четкое определение образовательной программы. Определение образовательной программы в МСКО учитывает разнообразные возможности, доступные в различных странах, для достижения сопоставимости программ на международном уровне.

18. В рамках образовательной программы образовательная деятельность может быть также сгруппирована по подкомпонентам, которые в различных национальных контекстах описываются как «курсы», «модули», «разделы», и/или «предметы». В МСКО понятие «курс» равнозначно понятию «модуль», «раздел», и/или «предмет». Образовательная программа может включать важные компоненты, которые обычно не считаются курсами, например, деятельность на основе игр, практические занятия, научно-исследовательские проекты, подготовку диссертации. 
19. Классификация образовательных программ определяет статистическую отчетность по системам образования, например, количество учащихся в учебных заведениях, поступивших, преподавателей и других человеческих и финансовых ресурсов. Статистика по образовательной программе позволяет получить информацию о связи между входными данными (поступившие), об образовательном процессе (учащиеся) и выходными данных (полученная квалификация).

20. В контексте МСКО, квалификация - это официальное подтверждение, как правило, в форме документа, удостоверяющего успешное завершение образовательной программы или этапа образовательной программы. Квалификацию можно получить посредством: і) успешного завершения образовательной программы полностью; ii) успешного завершения этапа образовательной программы (промежуточная квалификация образования); или іiі) проверки знаний, навыков, компетенций, не зависящих от участия в образовательной программе. Успешным завершением программы считается достижение учащимся определенных целей обучения. Индивидуальные кредиты, полученные по результатам успешного завершения индивидуальных курсов (например, модулей или предметов), не считаются получением квалификации в соответствии с МСКО. В таких случаях достаточное количество кредитов или предметов, равных по продолжительности и/или охватывающих учебный план программы полностью, представляло бы квалификацию.

21. Согласно МСКО 2011, признанные квалификации соответствуют образовательной программе как соответствующей единице классификации. Термин «квалификация» в МСКО является синонимом термина «аттестат» об образовании. Другие термины, такие как «сертификат», «степень» или «диплом» - это типы квалификации, и они являются синонимичными друг другу в контексте МСКО. Классификация квалификаций, признанных соответствующими национальными властями, является основой статистических данных уровня полученного образования.

22. Сначала в МСКО дается классификация образовательных программ, а затем - классификация квалификаций. Классификация национальных образовательных программ в соответствии с МСКО является основным инструментом для отображения связей между образовательными программами и квалификациями. Тем не менее, в некоторых случаях, несколько программ могут вести к получению одной и той же квалификации, и одна программа - к получению нескольких различных квалификаций.

23. За последнее десятилетие признание (предварительного) обучения посредством неформального образования или информального обучения стало более типичным во многих странах. В МСКО 2011 представлена более точная классификация квалификаций, полученных посредством практического приобретения навыков, знаний и компетенций, сопоставимых с успешным завершением формальной образовательной программы и, признанных в рамках формальной квалификации.

24. МСКО 2011 не предназначена для непосредственной оценки компетенций отдельных учащихся в силу отсутствия прямой взаимосвязи между образовательными программами или квалификациями и действительными образовательными достижениями. Образовательные программы, по которым индивидуум обучался и которые успешно завершил, в лучшем случае, лишь приблизительно соответствуют полученным навыкам, знаниям и компетенций на момент завершения программы.

25. Национальные и региональные квалификационные системы могут быть полезными инструментами для дифференциации знаний, навыков и компетенций, относящихся к программам и квалификациям. Многие страны используют подобные системы для описания уровней компетенции и навыков населения для оценки образовательных достижений. Странам рекомендуется обозначить четкую связь между МСКО и национальной или региональной квалификационной системой, если таковые существуют. 


\section{ГЛАВА 3 ПРОГРАММЫ, ОХВАТЫВАЮЩИЕ НЕСКОЛЬКОУРОВНЕЙ МСКО, ПОСЛЕДОВАТЕЛЬНЫЕ ПРОГРАММЫ В РАМКАХ ОДНОГО УРОВНЯ И МОДУЛЬНЫЕ ПРОГРАММЫ}

26. При классификации национальных образовательных программ по уровням МСКО, точки перехода национальных программ и точки выхода на рынок труда не всегда совпадают с точками перехода с одного уровня МСКО на другой. Можно выделить три таких случая: і) программы, охватывающие два или более уровней МСKO; іi) две и более последовательные программы в рамках одного уровня МСKO; и іiі) программы, проводящиеся как модули или курсы без четко определенной последовательности.

27. Национальная образовательная программа, продолжительность которой превышает критерий, определённый для данного уровня МСКО (см. пункты 70 и 71), считается выходящей за рамки одного уровня. Поэтому необходимо определить точку (или точки) перехода от одного уровня МСКО к следующему в рамках курса программы в соответствии с критерием. Например, если национальная программа начального образования длится восемь лет или более, ее последние классы следует отнести к уровню МСКО 2 (то есть, шесть первых классов следует отнести к уровню МСКО 1, а два последних класса к уровню МСКО 2).

28. При классификации программы, выходящей за рамки одного уровня МСКО, для соотнесения лет обучения с соответствующим уровнем МСКО следует использовать существующие в рамках программы точки перехода, такие, как этапы или промежуточные квалификации. Если такие точки перехода отсутствуют, то, при определении границ между уровнями МСКО, следует руководствоваться обычной совокупной продолжительностью уровня МСКО (см. пункт 71). Для более подробной информации об уровнях МСКО см. главу 9.

29. Программы, выходящие за рамки одного уровня МСКО, как правило, не предусматривают получение квалификации при завершении более низкого уровня МСКО. В таких случаях может быть использован другой критерий для определения завершения уровня, например, «полное посещение занятий последнего года», относящихся к более низкому уровню МСКО, или «доступ к обучению», относящемуся к более высокому уровню МСКО.

30. В отчетности существуют особые положения, касающиеся программ, охватывающих разные уровни МСКО. Показатели, определяющие количество учащихся, следует распределять по уровням МСКО, используя статистические показатели по классам или годам для проведения разграничений. Финансовые и человеческие ресурсы также могут оцениваться по уровню (или группе уровней, например, третичное образование). При представлении данных о впервые поступивших или о выпускниках уровня MCKO, каждый уровень, который охватывает программа, рассматривается отдельно.

31. Чтобы соответствовать критерию продолжительности для уровней МСКО (см. пункты 70 и 71), возможно, будет необходимо классифицировать две и более последовательные программы в рамках одного уровня МСКО, если их общая (но не индивидуальная) продолжительность будет соответствовать минимальному критерию продолжительности. В таких случаях, в отчетности по уровням МСКО продвижение вперёд от первой ко второй или последующей программам в системе образования не отражается, когда предоставляются данные по выпускникам определенного уровня МСКО, но может быть отражено в отчетности по любым признанным промежуточным квалификациям образования, полученным в подкатегориях: і) «неполное завершение» уровней МСКО 2 и 3 или іi) «уровень не завершен» в рамках других уровней МСКО (см. пункт 60). Подобные ситуации могут возникнуть, если в системе образования уровни МСКО 1-3 представлены последовательностью из четырех, а не из двух или трех программ. 
ГЛАВА 3. Программы, охватывающие несколько уровней МСКО, последовательные программы в рамках одного уровня и модульные программы

32. Две и более последовательные программы, представленные в рамках одного уровня МСКО, требуют особого внимания при составлении статистических отчетов. Следует объединить данные по учащимся на всех программах уровня. В данных о поступивших учитываются лишь те, кто зарегистрирован на первую программу уровня MCKO, а в данных о выпускниках приводятся сведения лишь о тех, кто завершил последнюю программу в последовательности в рамках одного уровня. Что касается уровня полученного образования, лишь признанное успешное завершение последней программы в последовательности рассматривается как завершение уровня. Признанное успешное завершение программ на более раннем этапе в рамках уровня МСКО рассматривается в подкатегориях «неполное завершение» или «уровень не завершен» (см. пункт 60).

33. Модульные программы позволяют учащимся гибко составлять содержание образования за счет сочетания различных курсов или модулей. Комбинация модулей считается образовательной программой, если соответствует определению образовательной программы, представленному в MCKO (см. пункт 11).

34. Все участники модулей, составляющих образовательную программу, считаются учащимися на программе, даже если они выбирают лишь несколько модулей, которые по продолжительности могут быть короче, чем обычная продолжительность данного уровня МСКО. Модульная программа считается успешно завершенной, если успешно завершены требуемое количество и типы модулей образовательной программы. 


\section{ГЛАВА 4 ЧТО ОХВАТЫВВЕТ МСКО?}

35. МСКО 2011 охватывает образовательные программы формального и неформального образования, доступные индивидууму на протяжении жизни. Квалификации, признанные соответствующими национальными органами управления образованием, вне зависимости от того, как они получены (например, путем успешного завершения программы формального образования или программы в рамках информального обучения), используются для оценки уровня полученного образования. МСКО не охватывает программы информального, случайного или несистемного обучения, а также квалификации, которые не признаны. Формальное и неформальное образование охватывает различные образовательные программы, разработанные в рамках национального контекста, такие как предварительное образование, обычное образование, программы «второго шанса», программы по ликвидации неграмотности, образование для взрослых, непрерывное образование, открытое и заочное образование, стажировка, техническое и профессиональное образование, образование для учащихся с особыми потребностями.

36. Формальное образование - это институционализированное, целенаправленное, спланированное при участии государственных организаций и признанных государством частных организаций образование, что в целом составляет систему формального образования страны. Таким образом, программы формального образования признаются как таковые соответствующими национальными властями или равнозначными им организациями, например, любым учебным заведением в сотрудничестве с национальными или субнациональными органами образования. Формальное образование в основном состоит из программ предварительного образования (см. пункт 37). Профессионально-техническое образование, образование для учащихся с особыми потребностями и некоторые компоненты программ образования для взрослых зачастую рассматриваются как часть системы формального образования. Квалификации формального образования признаются по определению и поэтому рассматриваются МСКО. Институционализированным образованием считается такое образование, при котором организация предоставляет комплексные условия для образования, такие как отношения «ученик-учитель» и/или взаимодействие, специально предназначенное для целей образования и обучения.

37. Формальное образование, как правило, организуется в образовательных учреждениях, созданных для получения очного образования учащимися в системе, обеспечивающей непрерывность перехода от одной образовательной программы к другой. Это называется предварительным образованием, определяемым как формальное образование людей до их первого выхода на рынок труда, т. е. до тех пор, пока они будут получать образование в очной форме.

38. Формальное образование также включает обучение всех возрастных групп вместе с содержанием программ и квалификаций, соответствующих квалификациям первоначального образования. Программы, обучение по которым ведется частично без отрыва от производства, могут также рассматриваться как формальное образование, если они ведут к получению квалификации, признаваемой национальными органами образования, или равнозначными организациями. Обучение в рамках таких программ часто ведется при сотрудничестве учебных заведений и работодателей (например, стажировка).

39. Подобно формальному образованию, но являясь отличным от информального, случайного обучения или несистемного обучения, неформальное образование - это образование, которое институционализировано, целенаправленно и спланировано лицом или организацией, обеспечивающей предоставление образовательных услуг. Определяющей характеристикой неформального образования является то, что оно является дополнением и/или альтернативой формальному образованию в обучении в течение всей жизни индивидуума. Обучение в рамках таких программ часто ведется для обеспечения всеобщего права доступа к образованию. 
Неформальное образование доступно людям всех возрастов, но оно не обязательно имеет непрерывную направленную структуру; оно может быть коротким по продолжительности и/ или низким по интенсивности; и оно, как правило, также организуется в форме краткосрочных курсов, мастер-классов или семинаров. Неформальное образование чаще всего ведет к получению квалификаций, которые не признаются квалификациями формального образования или их эквивалентами, соответствующими национальными или субнациональными органами образования, либо квалификации совсем не присваиваются. Однако официально признанные квалификации могут быть получены в результате исключительного участия в специальных программах неформального образования: подобное часто происходит, если в рамках неформального образования восполняются компетенции, приобретенные в других контекстах.

40. В зависимости от национального контекста, неформальное образование может охватывать программы по ликвидации неграмотности взрослых и молодежи, и программы для детей, не посещающих школу, а также программы по развитию жизненных и трудовых навыков, программы, направленные на социальное и культурное развитие. Оно может включать подготовку на рабочем месте для совершенствования или адаптации имеющихся квалификаций или навыков, обучение безработных или представителей экономически неактивного населения, а также в некоторых случаях возможные пути перехода к формальному образованию и обучению. Неформальное образование может также включать учебную деятельность, направленную на самообразование и, следовательно, не обязательно связанную с работой.

41. Успешное завершение программы неформального образования и/или получение образовательной квалификации обычно не дает доступ к высшему уровню образования, если только программа не утверждена в системе формального образования и не признана соответствующими национальными и субнациональными органами образования (или равнозначными им).

42. Для статистической отчетности МСКО 2011 четко разграничивает понятия формального и неформального образования. МСКО 2011 рекомендует использовать критерий эквивалентности содержания и/или полученной квалификации для классификации программ неформального образования. Более подробная информация, касающаяся классификации программ неформального образования, представлена в приложении V. На данный момент процесс сбора данных в области образования (классификации, опросы, переписи, и т.д.) в международном масштабе главным образом направлен на формальное образование.

43. Информальное обучение не рассматривается в рамках МСКО для оценки участия в образовании, хотя признанные квалификации, полученные в рамках информального обучения, учитываются при определении уровня полученного образования. Информальное обучение определяется как формы обучения, которые являются целенаправленными или тщательно спланированными, но не институционализированными. Соответственно, оно менее организованно и менее структурировано, чем формальное или неформальное образование. Информальное обучение может включать учебную деятельность в семье, на рабочем месте, по месту жительства и в повседневной жизни, и направленность его определяется самостоятельно, семьей или социумом. Как формальное и неформальное образование, информальное обучение следует отличать от случайного обучения или несистемного обучения.

44. МСКО также не рассматривает случайное или несистемное обучение, а именно, различные формы обучения, которые не являются организованными и предполагают коммуникацию, не предназначенную для обучения. Случайное или несистемное обучение может стать побочным продуктом повседневной деятельности, мероприятий или коммуникации, не предназначенных для целенаправленного образования или учебной деятельности. Примерами подобного обучения может быть общение при встрече, радио- и телепередачи, не являющиеся образовательными программами. 
45. Основные сквозные классификационные переменные МСКО - это уровни и области образования (об областях образования см. приложение IV). В рамках уровней МСКО программы и квалификации классифицируются далее по дополнительным параметрам. К ним относятся:

- ориентация программы;

- завершение уровня MCKO;

- доступ к более высоким уровням МСКО; и

- положение в национальной системе степеней и квалификаций.

Не все дополнительные параметры применимы ко всем уровням. Кроме того, уровень МСКО 0 далее подразделяется в соответствии с видом программы и возрастом целевой группы. Категории и подкатегории этих дополнительных параметров позволяют провести более тщательный сбор и представление сопоставимых на межнациональном уровне данных.

46. Другие описательные характеристики и свойства программ и квалификаций, помимо описанных в МСКО, могут включать лицо или организацию, предоставляющие образовательные услуги, обстановку, в которой осуществляется обучение, местоположение, институциональный контекст, форму обучения, тип участников или форму участия. Хотя сами эти характеристики не включены в МСКО как дополнительные параметры, они играют важную роль при выявлении различий в сущности этих программ во многих странах и при определении охвата собираемых данных.

Уровни

47. Понятие «уровни» образования представлено упорядоченным набором категорий, группирующих образовательные программы в соответствии с градацией учебного опыта, а также знаний, навыков и компетенций, которые призвана обеспечить образовательная программа. «Уровень МСКО» отражает степень сложности и специализации содержания образовательной программы от основного до сложного.

48. Таким образом, уровни образования представляют собой концепцию, основанную на предположении о том, что образовательные программы можно сгруппировать в упорядоченный ряд категорий. С учетом сложности образовательного контекста эти категории представляют собой масштабные этапы в движении по образовательному маршруту. Чем более продвинутой является программа, тем выше уровень образования.

49. Классификация программ, основанная на продвижении по уровням, направлена на отражение полного спектра возможных путей перехода с одной образовательной программы на другую, доступных в системах образования: большинство программ системы образования предоставляют несколько возможных путей перехода от уровня МСКО 0/1 к уровню МСКО 8 (см. схему 2 в приложении I). Поскольку системы образования предоставляют множество разветвленных маршрутов, альтернативные последовательности программ и программы «второго шанса», возможны различные пути перехода с одной образовательной программы на другую. Однако учащиеся редко проходят через все возможные уровни.

50. Классификация образовательных программ по уровням направлена на отражение их содержания. Однако учебные планы слишком разнообразны, многоаспектны и сложны для согласованной прямой оценки и сопоставления содержания программ систем образования. В связи с отсутствием 
прямых измерителей классификации содержания образования в МСКО применяются косвенные (опосредованные) критерии, которые помогают отнести отдельно взятую образовательную программу к соответствующему уровню МСКО. Иногда косвенные критерии могут быть специфичны для каждого уровня МСKO, и их описание дается в соответствующих главах. Общее описание критериев продолжительности и совокупной продолжительности каждого уровня дается в конце данной главы.

51. Косвенные критерии подразделяются на основные и дополнительные. Основные критерии указывают на необходимые характеристики образовательных программ на соответствующем уровне МСКО. Дополнительные критерии указывают на характеристики, присутствующие во многих, но не во всех образовательных программах уровня МСКО (см. главу 9).

52. Основным критерием для классификации программы является критерий сложности и специализации ее содержания и то, каким образом содержание отражено в косвенных критериях. В качестве критерия классификации не следует замещать учебное содержание (содержание образования) институциональным контекстом. Например, обучение на уровне МСКО 4 может проходить в учебных заведениях, где обычно обучаются по программам MCKO 5 или 6.

\section{Ориентация}

53. Ориентация программы различается на уровнях МСКО со 2-го по 5-ый с возможностью применения на уровнях МСКО 6-8. Существует две категории: общее и профессиональнотехническое образование. На уровнях третичного образования термины «академическое образование» и «профессиональное образование» будут использоваться вместо терминов «общее» и «профессионально-техническое», соответственно. В МСКО 2011 еще не дано более четкое определение терминов «академическое» и «профессиональное» для более высоких уровней MCKO, но на основе примеров областей образования, открываются перспективы для разведения понятий академической и профессиональной ориентации в будущем. До момента чёткого определения терминов «академического» и «профессионального» образования, на уровне МСКО 5 будут использоваться определения «общее образование» и «профессионально-техническое образование».

54. Профессионально-техническое образование определяется как образовательные программы, разрабатываемые для приобретения учащимися знаний, навыков и компетенций для занятий определенным видом или видами профессиональной деятельности. Эти программы могут включать такие компоненты, как обучение на базе предприятий (например, стажировка, дуальные образовательные программы). Успешное завершение таких программ ведет к получению пользующихся спросом на рынке труда профессиональных квалификаций, признанных соответствующими национальными властями и/или рынком труда как профессиональноориентированные.

55. Общее образование определяется как образовательные программы, разрабатываемые для расширения общих знаний, развития навыков и компетенций, а также навыков чтения, письма и счета, часто направленные на подготовку учащихся к обучению по более продвинутым программам того же или более высокого уровня МСКО и на формирование основы для обучения на протяжении всей жизни. Обучение по этим программам обычно проводится на базе школы или колледжа. Общее образование включает образовательные программы, разработанные для подготовки учащихся к поступлению на программы профессионально-технического образования. Данные программы не направлены на подготовку к трудоустройству по определенному виду или видам профессий и на непосредственное получение востребованной на рынке труда квалификации. 


\section{Завершение уровня и доступ к более высоким уровням образования}

56. Требования к успешному завершению образовательной программы, т.е. достижению целей обучения, как правило, оговариваются в спецификации программы и обычно включают:

- требования к посещаемости (обучение и регулярная посещаемость на протяжении последнего года программы); и/или

- демонстрация приобретения ожидаемых знаний, навыков и компетенций.

57. Приобретение знаний, навыков и компетенций, обозначенных в целях обучения образовательной программы, обычно подтверждается:

- сдачей (т.е. успешным прохождением) выпускного экзамена или экзаменов по предметам учебного плана;

• накоплением определенного числа кредитов в процессе обучения; или

- успешной сдачей государственного экзамена, подтверждающего овладение знаниями, навыками и компетенциями.

В рамках формального образования успешное завершение обычно ведет к получению квалификации, признаваемой соответствующими национальными властями в области образования.

58. Образовательные программы уровней МСКО 1 и 2 (а иногда уровней МСКО 3 и 4) не всегда завершаются получением квалификации. В этих случаях для определения успешного завершения вместо «квалификации» следует использовать другие критерии; например, посещение полного последнего года программы или доступ к более высокому уровню образования.

59. Программы уровней МСКО 1-3 всегда считаются успешно завершенными, когда полученная квалификация открывает прямой доступ к более высокому уровню МСКО. В случае с уровнем МСКО 3 «более высокий уровень» означает доступ к уровням MCКО 5, 6 или 7. Квалификации рассматриваются как предоставляющие доступ к более высокому уровню МСКО, даже если этот доступ ограничен только обучением на небольшом количестве программ на более высоком уровне MCKO. Успешное завершение программ, относящихся к уровням МСКО 4-8, рассматривается как завершение уровня. Тем не менее, в случае определения уровня полученного образования, признанная квалификация, полученная до завершения программы (например, успешное завершение этапа программы с получением промежуточной квалификации образования) относится к более низкому уровню МСКО. Когда полученная квалификация не дает прямого доступа к более высокому уровню МСKO, успешное завершение программы может считаться завершением уровня без прямого доступа или не завершением уровня. На уровнях МСКО 2 и 3 только, полученные квалификации, не дающей прямого доступа к более высоким уровням МСКО, может считаться завершением уровня без прямого доступа, неполным завершением уровня или не завершением уровня.

60. Образовательные программы и соответствующие квалификации в рамках уровней МСКО 2 и 3 подразделяются на четыре подкатегории:

i) уровень не завершен (и поэтому нет прямого доступа к более высокому уровню МСКО, в данном случае от уровней МСКО 3 к уровням 5, 6 или 7);

ii) неполное завершение уровня без прямого доступа к более высокому уровню МСКО;

iii) завершение уровня без прямого доступа к более высокому уровню МСКО; и

iv) завершение уровня с прямым доступом к более высокому уровню МСКО (в данном случае от уровня МСКО 3 к первой программе третичного образования на уровнях 5, 6, или 7). 
61. Успешное завершение программ уровней MCKO 2 и 3, которое не дает доступа к программам на более высоком уровне МСКО (в данном случае переход от уровня МСКО 3 к уровню 5, 6 или 7), рассматривается в рамках подкатегорий «завершение уровня» и «неполное завершение уровня» В том случае, если программа соответствует следующим критериями: і) продолжительность обучения на программе не менее двух лет на данном уровне MCKO; и іi) совокупная продолжительность, начиная с уровня МСКО 1, не менее 8 лет для программ уровня МСКО 2 и не менее 11 лет для программ уровня МСКО 3. Успешное завершение более коротких программ в рамках одного из уровней МСКО считается лишь успешным завершением программы. Для определения уровня полученного образования, любая признанная квалификация, полученная путем завершения программы короткого цикла, классифицируется как более низкий уровень МСКО, чем сама программа.

62. Программы, которые:

а) не соответствуют критерию содержания и/или критериям минимальной и совокупной продолжительности, относятся к категории 1 (уровень не завершен).

b) соответствуют критерию содержания и критериям минимальной продолжительности и совокупной продолжительности, являющимся частью последовательности программ в рамках одного уровня МСКО (но не являющиеся крайними в последовательности), и, таким образом, которые не дают прямого доступа к более высокому уровню МСКО, относятся к категории 2 (неполное завершение уровня).

с) соответствуют критерию содержания и критериям минимальной продолжительности и совокупной продолжительности и являются завершающими в последовательности программами, относятся к категории 3 (завершение уровня без прямого доступа). Такие программы обычно напрямую ведут к получению пользующихся спросом на рынке труда соответствующих квалификаций.

d) соответствуют уровню МСКО 3, дающие прямой доступ только к уровню МСКО 4, относятся к категории 3 (завершение уровня без прямого доступа).

е) дают прямой доступ к третичному образованию на уровнях MCKO 5, 6 или 7 относятся к категории 4 (завершения уровня с прямым доступом).

63. Программа для особых групп участников (взрослых или учащихся с особыми потребностями) может иметь более короткую или более долгую продолжительность, чем подобные программы в рамках обычного образования на данном уровне МСКО. Однако успешное завершение программы будет считаться успешным завершением уровня при условии, что полученная квалификация подтверждает овладение уровнем знаний, навыков и компетенций, равнозначных полученным в рамках программ обычного образования на том же уровне.

64. Участие в программе без её успешного завершения не рассматривается как завершение уровня или неполное завершение уровня и, за исключением уровней МСКО 0 и 1, не учитывается для определения уровня полученного образования. Таким образом, уровень полученного образования тех, кто не завершил данную программу успешно, является наивысший уровень, который они достигли до поступления на эту программу.

65. В то время как критерии для определения завершения уровня применимы к успешному завершению и, таким образом, лишь напрямую применимы к отдельным лицам, образовательные программы в целом классифицируются по уровню наивысшей возможной квалификации, к которой они готовят, даже если участники и не овладеют этой квалификацией. 


\section{Положение в национальной структуре степеней и квалификаций}

66. Программы уровней МСКО 6 и 7 различаются по их положению в структуре национальных степеней и квалификаций. Необходимо учитывать последовательности национальных программ и квалификаций для правильного определения верного количества впервые поступивших и выпускников учебных заведений третичного образования (или соответствующих ему уровней). Положение, которое присваивается программе, основывается на последовательности степеней и квалификаций в рамках национальных систем третичного образования.

67. Программы уровня МСКО 6, которые не требуют предварительного завершения других программ уровня 6 при поступлении, классифицируются как программы первой степени. Все остальные программы уровня МСКО 6 классифицируются как программы второй степени.

68. Программы уровня МСКО 7, которые не требуют предварительного завершения уровня 6 для поступления, классифицируются как программы первой степени. Другие программы уровня 7 могут потребовать или предварительного завершения программ уровня 6, или других программ уровня 7. Эти программы классифицируются отдельно в МСКО для более точного определения количества впервые поступивших и выпускников уровня МСКО 7.

\section{Критерии продолжительности и совокупной продолжительности}

69. Ниже подробно описаны критерии продолжительности в связи с их важностью для классификации программ по уровням и для определения завершения уровня. Остальные критерии рассматриваются в главе 9.

70. В качестве критериев для классификации программ формального образования используются следующие рамки продолжительности уровней МСKO:

- МСКО 0: критерий продолжительности отсутствует, однако, программа должна насчитывать не менее эквивалента 2 часов в день и 100 дней в году образовательной деятельности для того, чтобы быть классифицированной как программа уровня МСКО 0;

- MCКО 1: продолжительность обычно составляет от 4 до 7 лет. Наиболее распространенная продолжительность - 6 лет;

- MCKO 2: продолжительность, как правило, составляет от 2 до 5 лет. Наиболее распространенная продолжительность - 3 года;

- MCKO 3: продолжительность, как правило, составляет от 2 до 5 лет. Наиболее распространенная продолжительность - 3 года;

- МСКО 4: продолжительность, как правило, составляет от 6 месяцев до 2-3 лет;

- MCКО 5: продолжительность, как правило, составляет от 2 до 3 лет;

- МСКО 8: продолжительность составляет не менее 3 лет.

Типичную продолжительность уровней МСКО 6 и 7 легче определить относительно продолжительности программ на соответствующих уровнях, так как продолжительность уровня МСКО зависит от последовательности программ, предлагаемых на этих уровнях в разных странах. 
- MCKO 6: продолжительность программы Бакалавра или её эквивалента, как правило, составляет от 3 до 4 и более лет, если программа непосредственно следует за уровнем МСКО 3, и 1-2 года, если программа следует за другой программой уровня МСKO 6;

- МСКО 7: продолжительность программы Мастера или её эквивалента, как правило, составляет от 1 года до 4 лет, если программа следует за уровнем МСКО 6, или от 5 до 7 лет, если программа непосредственно следует за уровнем МСКО 3.

71. В качестве критериев для классификации программ формального образования по уровням в МСКО используются следующие рамки совокупной продолжительности:

- MCКО 1+2: типичная совокупная продолжительность составляет 9 лет, но может варьироваться от 8 до 11 лет; и

- MCKO 1+2+3: типичная совокупная продолжительность составляет 12 лет, но может варьироваться от 11 до 13 лет. Поступление на программы третичного образования обычно требует не менее 11 лет обучения на уровнях МСКО 1-3.

72. При применении критериев продолжительности к очно-заочным (вечерним) или модульным программам теоретическая продолжительность программы должна измеряться в эквиваленте очного обучения.

73. Несмотря на то, что главной целью МСКО является содействие сбору и применению сопоставимых в области образования данных, национальная специфика требует гибкого подхода в определении продолжительности по уровням. Поэтому в пунктах 70 и 71 представлены временные рамки продолжительности по годам. В оптимальном варианте при классификации программ используется их наиболее типичная продолжительность.

74. Продолжительность по уровням и совокупная продолжительность, представленные в пунктах 70 и 71, служат в качестве руководства. Тем не менее, институциональные точки перехода могут быть использованы в качестве критериев при определении соответствия программы уровню МСКО. Выбор национальных точек перехода для сопоставления с международными категориями предопределяется содержанием образовательных программ, а не их (совокупной) продолжительностью. 


\section{ГЛАВА 6 ТИПЫ ДАННЫХ}

75. МСКО главным образом применяется для работы со статистическими данными об учащихся, поступивших, выпускниках и об уровне полученного образования. МСКО не является пособием по сбору данных и не дает подробного описания того, как работать со статистическими единицами и представлять собранные данные. Тем не менее, следующие принципы следуют принимать во внимание при применении МСКО для разных типов статистики.

\section{Количество учащихся, посещаемость и впервые поступившие}

76. Для правильного учета учащихся, посещаемости и впервые поступивших, индивидуумов следует распределить по уровням, категориям и подкатегориям МСКО. Институциональный контекст не должен служить основой для сбора статистических данных. Данные об учениках/студентах одного и того же учебного заведения, но различных уровней МСКО, должны подаваться отдельно, при необходимости с использованием оценочных данных. Данные об учащихся образовательных программ, охватывающих несколько уровней МСКО, следует подавать, используя статистические данные по классам и этапам.

77. Учащиеся распределяются по уровням и категориям МСКО в соответствии с характеристиками программы, а не с характеристиками отдельных учащихся. Например, категория дошкольного образования распространяется на детей от 3 лет и старше, однако дети, не достигшие этого возраста, но зачисленные на такие программы, должны быть также отнесены к этой категории. Подобным образом, статистические данные, использующие категории доступа к более высокому уровню, должны основываться на разработанной программе, а не на индивидуальных образовательных маршрутах учащихся.

78. Впервые поступивших на уровень МСКО следует отличать от поступивших на образовательную программу, но не поступивших на новый уровень (т.е. от тех, кто уже поступил на этот уровень MCKO ранее). При предоставлении данных о поступивших на уровень МСКО, поступивших на образовательную программу, которой предшествует программа того же уровня, исключаются из числа поступивших. Для программ, охватывающих два уровня МСКО, индивидуумов, поступивших на первый год обучения более высокого уровня МСКО, следует рассматривать как поступивших на уровень MCKO, даже если в рамках национального контекста они продолжают обучение по той же программе.

\section{Выпускники}

79. К выпускникам уровня МСКО относятся те, кто поступил и успешно закончил образовательную программу, относящуюся к подкатегории «завершение уровня». Теоретически, только тех, кто успешно завершил уровень в целом или ряд уровней, на который они были зачислены (например, получение первой степени в системе третичного образования), следует учитывать для обеспечения связи данных о поступивших, учащихся и выпускниках. Студенты, которые получают ту же квалификацию или равнозначную ей в результате успешного завершения лишь одного этапа уровня MCKO, не считаются выпускниками.

80. Выпускник должен быть учтён единожды на любом наивысшем завершённом уровне МСКО. Это особенно важно в отношении второго этапа среднего образования и третичного образования, где ряд программ может следовать одна за другой в рамках одного уровня МСКО. Правильный учет выпускников предполагает, что отдельного учащегося отслеживают на протяжении уровня (или ряда уровней) от поступления до завершения. На практике зачастую реализовать такой подход невозможно, и потребуется разработка методов оценки подсчета количества выпускников, например посредством проведения повторного опроса когорты выпускников по образцу идентичного формата. 


\section{Уровень полученного образования}

81. Уровень полученного индивидуумом образования определяется наивысшим уровнем МСКО завершенным индивидуумом. На практике уровень полученного образования обычно измеряется относительно самой высокой, успешно завершенной образовательной программы, которая обычно подтверждается признанной квалификацией. Признанная промежуточная квалификация относится к более низкому уровню, чем сама программа.

82. Образовательная программа считается успешно завершенной, когда учащийся или студент посещает и завершает программу формального образования и получает признанную квалификацию (см. пункты 56-58).

83. Соответствующие национальные органы образования могут признавать квалификации, полученные в рамках неформального образования или по результатам оценки навыков, приобретенных в рамках информального обучения как эквивалент квалификациям формального образования. В соответствии с МСКО такие квалификации также учитываются в рамках концепта уровня полученного образования. МСКО не охватывает квалификации, полученные в рамках неформального образования, или квалификации, подтверждающие наличие навыков, которые не признаются как эквивалент квалификаций, полученных в рамках формального образования (см. пункт 35).

84. Данное МСКО определение уровня полученного образования следует отличать от других понятий, относящихся к уровню достижений отдельных лиц. Индивидуальные достижения могут включать образовательные уровни, программы которых посещены, но успешно не завершены, или фактические знания, навыки и компетенции индивидуума (например, уровень владения навыками чтения, письма и счета), поскольку их можно оценить посредством типового тестирования или в процессе обучения.

85. Индивидуумы, посетившие лишь часть национальной программы и чей уровень не соответствует требованиями к завершению программы (например, провал на финальном экзамене), не относятся к успешно завершившим программу. Их следует классифицировать в соответствии с самым высоким успешно завершенным уровнем MCКО (т. е. до поступления на программу, которая не завершена успешно).

86. Для классификации уровня полученного образования смысловое содержание уровня 0 отличается по значению от классификации образовательных программ: это значит, что уровень МСКО 1 успешно не завершен. В данную группу включены те, кто никогда не посещал образовательную программу, или те, кто посещал программу для детей младшего возраста или программу начального образования без успешного завершения программы уровня МСКО 1. Рассматривается несколько категорий и подкатегорий для данного уровня полученного образования (см. таблицу 4).

87. Уровень полученного образования может быть классифицирован в соответствии с законченным (или не полностью завершенным) уровнем MCKO, ориентацией программы и доступом к более высоким уровням МСКО. Если индивидуум успешно закончил один и тот же уровень МСКО более одного раза (например, обучаясь на двух разных программах, которые предлагаются как параллельные опции), для статистики следует использовать характеристики самой последней, полученной квалификации.

88. Статистика по уровню полученного образования охватывают индивидуумов всех возрастных групп, некоторые или многие из которых, возможно, завершили образовательные программы или получили соответствующие квалификации, которые отличаются от получаемых в настоящее время. Для сопоставимости показателей в течение времени и разных когорт участников уровень полученного образования следует классифицировать, опираясь на характеристики образовательных программ и признанных квалификаций в момент их успешного завершения. 


\section{7 СХЕМЫ КОДИРОВАНИЯ}

89. Классификация МСКО состоит из параллельных схем кодирования образовательных программ (МСКО-ПРОГРАММЫ, или МСКО-П) и уровней полученного образования (МСКО-УРОВЕНЬ, или МСКО-У). В рамках данных схем существует девять отдельных уровней. В рамках каждого уровня используются дополнительные параметры, чтобы в случае необходимости определить категории и подкатегории. Как для образовательных программ, так и для уровня образования используются системы трехзначного кодирования.

\section{Таблица 1. Кодирование уровней МСКО (первая цифра)}

\begin{tabular}{|c|l|c|l|}
\hline \multicolumn{2}{|c|}{ МСКО - Программы (МСКО-П) } & \multicolumn{2}{|c|}{ МСКО - Уровень (МСКО-У) } \\
\hline 0 & Программы развития детей младшего возраста & 0 & Ниже начального образования \\
\hline 1 & Начальное образование & 1 & Начальное образование \\
\hline 2 & Первый этап среднего образования & 2 & Первый этап среднего образования \\
\hline 3 & Второй этап среднего образования & 3 & Второй этап среднего образования \\
\hline 4 & Послесреднее нетретичное образование & 4 & Послесреднее нетретичное образование \\
\hline 5 & Короткий цикл третичного образования & 5 & Короткий цикл третичного образования \\
\hline 6 & Бакалавриат или его эквивалент & 6 & Бакалавриат или его эквивалент \\
\hline 7 & Магистратура или её эквивалент & 7 & Магистратура или её эквивалент \\
\hline 8 & Докторантура или её эквивалент & 8 & Докторантура или её эквивалент \\
\hline 9 & Не классифицируется & 9 & Не классифицируется \\
\hline
\end{tabular}

\section{Таблица 2. Кодирование категорий МСКО (вторая цифра)ำ}

\begin{tabular}{|c|c|c|c|}
\hline 0 & Далее не определен & 0 & Далее не определен \\
\hline 2 & Дошкольное образование & 2 & $\begin{array}{l}\text { Некоторые программы образования детей младшего } \\
\text { возраста }\end{array}$ \\
\hline 4 & Общие/академические & 4 & Общие/академические \\
\hline 5 & Профессионально-технические/профессиональные & 5 & Профессионально-технические/профессиональные \\
\hline 6 & Ориентация программы не определена² & 6 & Ориентация программы не определена ${ }^{3}$ \\
\hline 9 & Не классифицировано & 9 & Не классифицировано \\
\hline \multicolumn{4}{|c|}{$\begin{array}{l}\text { Уровень: участие (МСКО-У уровень 0), ориентация (МСКО-У уровни 2-5), } \\
\text { Применимо для уровней 6-8 МСКО-П } \\
\text { Применимо для уровней 5-8 МСКО-у }\end{array}$} \\
\hline
\end{tabular}




\section{Таблица 3. Кодирование подкатегорий МСКО (третья цифра)'}

\begin{tabular}{|c|c|c|c|}
\hline \multicolumn{2}{|r|}{ МСКО - Программы (МСКО-П) } & \multicolumn{2}{|r|}{ МСКО -Уровень (МСКО-У) } \\
\hline 0 & Далее не определено & 0 & Далее не определено² \\
\hline 1 & $\begin{array}{l}\text { Признанное успешное завершение программы недостаточно для } \\
\text { завершения или неполного завершения уровня МСКО (и таким образом } \\
\text { без прямого доступа к программам на более высоком уровне МСКО) }\end{array}$ & 1 & Не применимо \\
\hline 2 & $\begin{array}{l}\text { Признанное успешное завершение программы достаточно для } \\
\text { неполного завершения уровня МСКО, но без прямого доступа к } \\
\text { программам на более высоком уровне МСКО }\end{array}$ & 2 & $\begin{array}{l}\text { Неполное завершение уровня - без } \\
\text { прямого доступа к программам на более } \\
\text { высоком уровне МСКО }\end{array}$ \\
\hline 3 & $\begin{array}{l}\text { Признанное успешное завершение программы достаточно для } \\
\text { завершения уровня MCKO, но без прямого доступа к программам на } \\
\text { более высоком уровне }\end{array}$ & 3 & $\begin{array}{l}\text { Завершение уровня - без прямого } \\
\text { доступа к программам на более высоком } \\
\text { уровне }^{3}\end{array}$ \\
\hline 4 & $\begin{array}{l}\text { Признанное успешное завершение программы достаточно для } \\
\text { завершения уровня МСКО и с прямым доступом к программам на более } \\
\text { высоком уровне } \mathrm{MCKO}^{3,4}\end{array}$ & 4 & $\begin{array}{l}\text { Завершение уровня - с прямым } \\
\text { доступом к программам на более } \\
\text { высоком уровне } \text { MCKO }^{3,5}\end{array}$ \\
\hline 5 & Первая степень программы - бакалавриат или его эквивалент (3-4 года) & 5 & Не применимо \\
\hline 6 & $\begin{array}{l}\text { Длинная первая степень программы - бакалавриат или магистратура, } \\
\text { или их эквивалент }\end{array}$ & 6 & Не применимо \\
\hline 7 & $\begin{array}{l}\text { Вторая или последующая степень программы, следующая за } \\
\text { программой бакалавриата или её эквивалент }\end{array}$ & 7 & Не применимо \\
\hline 8 & $\begin{array}{l}\text { Вторая или последующая степень, следующая за программой } \\
\text { магистратуры или её эквивалент }\end{array}$ & 8 & Не применимо \\
\hline 9 & Не классифицируется & 9 & Не классифицируется \\
\hline \multicolumn{4}{|c|}{$\begin{array}{l}\text { 2. На уровнях МСКО-у } 1 \text { и 5-7, включая успешное завершение программы или этапа программы на более высоком уровне МСКО недостаточно для завершения уровня. } \\
\text { 3. В случае уровня МСКО 3, «более высокий уровень МСК0» относится к уровням МСКО-П 5-7. } \\
\text { 4. В случае уровней МСКО } 5 \text { и 8, все (полные) программы классифицируются как вид } 4 \text { вне зависимости от того, предоставляют ли они доступ к более высоким уровням } \\
\text { МСКО или нет. }\end{array}$} \\
\hline
\end{tabular}

90. Не все комбинации категорий и подкатегорий существуют и широко распространены. Поэтому представленные в данном документе трехзначные коды ограничены используемыми комбинациями. Полный список кодов представлен в приложениях 2 и 3. Если пользователи МСКО выделят дополнительные комбинации категорий и подкатегорий, список трехзначных кодов может быть расширен при использовании существующих кодов для обозначения дополнительных параметров. 
91. Институт статистики ЮНЕСКО (ИСЮ) является куратором МСКО и поэтому несет ответственность за развитие, поддержание, обновление и пересмотр данной классификации, а также за руководство по эффективному и последовательному использованию МСКО для сбора и анализа данных. ИСЮ поддерживает связь с кураторами других подобных классификаций для согласованного взаимодействия между ними.

92. Другие обязательства ИСЮ включают:

- описание применения структуры и деталей классификации при составлении и представлении статистических данных;

- продвижение применения МСКО для сопоставления статистических данных на межнациональном уровне;

- предоставление инструкций, обучение и техническую поддержку стран для обеспечения эффективного внедрения и использования классификации во всем мире;

- введение механизмов мониторинга для осуществления необходимой обратной связи с пользователями МСКО для решения проблем, возникающих в ходе ее применения (см. пункт 96); и

- создание Технической консультативной группы МСКО совместно с другими партнерами по сбору данных для пересмотра классификации МСКО и проведения консультаций по ее внедрению (см. пункт 97).

93. ИСЮ планирует разработать руководство для классификации национальных систем образования в соответствии с МСКО (изначально, для классификации программ и квалификаций формального образования). Руководство должно содержать указания и пояснения для интерпретации МСКО (включая примеры некоторых стран). Дополнительные инструкции и материалы по обучению могут быть предоставлены по необходимости и запросу пользователей.

94. Обучение по внедрению МСКО следует организовать в форме региональных семинаров, технической поддержки и сотрудничества в соответствии с потребностями и существующими возможностями стран. Обучающие материалы и их содержание будут обсуждаться ИСЮ в тесном сотрудничестве с партнерами по сбору данных. Особое внимание следует уделить преобразованию классификации МСКО 1997 в МСКО 2011 и руководству по классификации новых и переработанных программ.

95. ИСЮ планирует поддерживать базу данных классификаций национальных систем образования в соответствии с МСКО на своем веб-сайте (программы и квалификации программ формального образования). Они будут соответствующим образом обновляться для отражения изменений, происходящих в национальных системах образования с течением времени.

96. Для обеспечения соответствия с МСКО 2011 следует разработать механизмы контроля качества её внедрения. ИСЮ планирует работать в тесном сотрудничестве с организациями-партнерами по сбору данных (включая Евростат и ОЭСР) для обеспечения гарантии верного применения классификации МСКО и при необходимости обновления. Работая со странами-членами и соответствующими агентствами, ИСЮ утвердит механизм экспертной оценки национальных образовательных программ и квалификаций формального образования. 
97. Следует сформировать техническую консультативную группу МСКО для консультирования ИСЮ по вопросам классификации национальных программ и квалификаций, для пересмотра нынешней версии МСКО и для определения потенциальных областей для дальнейшего развития, хотя пересмотр МСКО не входит в сферу ее компетенции. Техническая консультативная группа МСКО должна включать ЮНЕСКО (как ведущее агентство в системе организаций ООН), кураторов других подобных классификаций (при необходимости), и ключевых партнеров по сбору данных в области образования, таких как ОЭСР и Евростат, как постоянных членов группы. Состав членов Технической консультативной группы должен быть сбалансирован технически и географически и, следовательно, дополнительно включать ряд работающих на непостоянной основе экспертов в области образования, статистики и классификаций, обладающих знанием МСКО и представляющих различные регионы мира, а также представителей научного сообщества и пользователей МСКО. 
98. В следующих подразделах даются определения девяти уровней МСКО. Структура каждого подраздела следующая:

А. Основные характеристики посвящены описанию целей программ на каждом уровне МСКО, способам организации обучения (параметрам процесса преподавания и обучения стандартным методам оценки, если применимо), а также требованиям к поступлению. Для некоторых уровней МСКО используются национальные названия программ, как возможный пример соответствия между национальными образовательными программами и соответствующие им уровнями МСКО.

В. Критерии классификации формально определяют, каким образом образовательные программы классифицируются на соответствующем уровне МСКО при использовании основных и вспомогательных критериев. Подробнее об общем понятии «уровень» МСКО см. главу 5.

С. В разделе о программах, охватывающих несколько уровней МСКО, предоставляются дальнейшие разъяснения по классификации образовательных программ, которые выходят за рамки одного уровня МСКО. Подробнее об основном понятии образовательных программ, охватывающих несколько уровней МСКО, см. главу 3.

D. Дополнительные параметры определяют характеристики, позволяющие провести различие разнообразных типов программ в рамках уровней МСКО в соответствии с ориентацией программы, завершением уровня и доступом к более высокому уровню МСКО, продолжительностью программы и положением в национальной структуре степеней и квалификаций. Подробнее об общей информации, касающейся дополнительных параметров, см. главу 5.

Е. Другие программы, включенные в уровень МСКО, представляют собой менее типичные программы или программы неформального образования (например, программы для учащихся с особыми потребностями, программы «второго шанса» или образовательные программы для взрослых), которые могут не соответствовать критериям классификации (например, типичный возраст поступления), но по уровню сложности содержания этих программ равнозначно программам, относящимся к этому уровню МСКО. Поэтому эти программы также отнесены к соответствующему уровню.

F. Классификация образовательных программ содержит подробные коды для уровней МСКО-П, категорий и подкатегорий, присвоенные образовательным программам.

G. Классификачия уровня образования содержит подробные коды для уровней МСКО-У, категорий и подкатегорий, присвоенных образовательным классификациям и подобным системам измерений успешного завершения образовательных программ. Она также определяет то, в каких случаях квалификацию следует отнести к уровню МСКО-У, отличному от уровня, соответствующего образовательной программе МСКО-П, посредством которой обычно осваивается данная квалификация.

99. После описания уровней МСКО в главе 10 представлены таблицы 20 и 21, указывающие соответствия версий МСКО 2011 и МСКО 1997. 


\section{УРОВЕНЬ МСКО О ОБРАЗОВАНИЕ ДЕТЕЙ МЛАДШЕГО ВОЗРАСТА}

\section{А. Основные характеристики}

100. Программы уровня МСКО 0, или «образование детей младшего возраста», как правило, разрабатываются на основе комплексного подхода для поддержания познавательного, физического, социального и эмоционального развития и для знакомства детей младшего возраста с организованным обучением в отрыве от семейной обстановки. Уровень МСКО 0 относится к программам обучения детей младшего возраста, которые содержат целевой образовательный компонент. Цель этих программ - развитие социо-эмоциональных навыков, необходимых для обучения в школе и жизни в обществе. Они также развивают некоторые навыки, необходимые для подготовки детей к учебной деятельности и к поступлению на обучение по программам начального образования.

101. На этом уровне программы не обязательно жестко структурированы, но призваны предоставить организованный и целенаправленный комплекс учебных мероприятий в безопасной естественной среде. Они позволяют детям учиться в интерактивном общении с другими детьми и под руководством персонала и воспитателей, как правило, посредством творческих занятий и занятий в игровой форме.

102. Программы уровня МСКО 0 рассчитаны на детей, не достигших возраста для поступления на уровень МСКО 1. Существует две категории программ уровня МСКО 0: программы развития детей младшего возраста и программы дошкольного образования. Программы первой категории имеют образовательный компонент, разработанный для детей в возрасте от 0 до 2 лет, а программы, включенные во вторую категорию, разработаны для детей с 3 лет и до начала обучения по программам начального образования.

103. Программы, относящиеся к уровню MCKO 0, могут называться по-разному, например, образование и развитие детей младшего возраста, игровая школа, reception, дошкольное образование или educación inicial. Что касается программ, известных под названием crèches, детский сад, ясли или guarderías, важно убедиться, что они соответствуют критериями классификации уровня МСКО 0, перечисленным ниже. В целях сопоставимости данных на международном уровне для обозначения уровня МСКО 0 используется термин «образование детей младшего возраста».

\section{B. Критерии классификации}

104. Для определения образования детей младшего возраста важны следующие критерии:

\section{Основные критерии}

а) Образовательная направленность программы (см. пункты 105 и 106);

b) Институциональный контекст (см. пункт 107);

c) Типичный целевой возраст детей, для которых разработана программа (см. пункты 102 и 108); и

d) Интенсивность/продолжительность программы (см. пункт 110).

\section{Дополнительные критерии}
а) Квалификация персонала (см. пункт 111);
b) Наличие нормативно-правовой базы (см. пункт 112); и
с) Обычно не является частью обязательного образования (см. пункт 113). 
105. Образовательная направленность программ развития детей младшего возраста характеризуется как учебная среда с опорой на зрительное восприятие и языковую среду. Эти программы способствует самовыражению, уделяя внимание овладению устной речью и её использованию для осмысленного общения. Существуют возможности для активной игры с целью развития координации и моторики у детей под наблюдением персонала и при интерактивном взаимодействии с ним. Программы, в которых предусмотрен лишь уход за детьми (присмотр, питание и забота о здоровье), в МСКО не включены.

106. Образовательная направленность программ дошкольного образования характеризуются как интерактивное взаимодействие друг с другом или с воспитателями, с помощью которых дети совершенствуют навыки устной речи и социальные навыки; начинает развиваться логическое мышление и умение аргументировать и общаться посредством мыслительного процесса. Их также знакомят с алфавитом и математическими понятиями, создают условия для изучения внешнего мира и окружающей среды. Участие под наблюдением воспитателей в занятиях по развитию крупной моторики (т.е. физические упражнения через игры и другие виды деятельности) и занятия в игровой форме могут быть использованы как обучающая возможность для создания условий для социального взаимодействия с другими детьми и развития навыков, самостоятельности и готовности к школе.

107. Программы уровня МСКО 0 обычно проводятся на базе школы или на базе другого учреждения для группы детей (например, на базе центра, по месту жительства, в домашних условиях). Полностью семейные занятия, которые могут быть целенаправленными, но не организованными в «программу» (например, информальное обучение детей их родителями, другими родственниками или друзьями) в МСКО 0 не включены.

108. В рамках уровня МСКО 0 программы развития детей младшего возраста ориентированы на детей в возрасте от 0 до 2 лет; а программы дошкольного образования - на детей в возрасте 3 лет и до начала уровня МСКО 1. Верхний возрастной предел для категории дошкольного образования теоретически зависит от возраста поступления на уровень МСKO 1, т. е. на обучение по программам начального образования (см. пункт 117).

109. При классификации необходимо обратить особое внимание на комбинированные программы образования детей младшего возраста, которые охватывают две подкатегории уровня МСКО 0 (т. е. образовательные программы для детей в возрасте от 0 лет и до начала обучения на уровне МСКО 1). Программы, продолжительностью в несколько лет, этапов или циклов, следует классифицировать следующим образом: программы, которые соответствуют критерию содержания программы в пункте 105, следует классифицировать как программы развития детей младшего возраста, а те из них, которые соответствуют критерию содержания программы в пункте 106, следует классифицировать как программы дошкольного образования. В тех случаях, где нет подразделения внутри программы, классификация по двум категориям должна основываться на возрасте участников.

110. Для улучшения международной сопоставимости МСКО рекомендует принимать во внимание следующую минимальную интенсивность и продолжительность программ: чтобы быть классифицированными в рамках MCKO, программы должны насчитывать не менее эквивалента 2 часов в день и 100 дней в году образовательной деятельности.

111. При необходимости, хорошим косвенным критерием для образовательной программы, где такое требование существует, является педагогическая квалификация воспитателей. Она необходима для определения различий между образованием детей младшего возраста и уходом за детьми, при котором специально подготовленный персонал не требуется. 
112. Там, где это уместно, хорошим косвенным (опосредованным) критерием для образовательной программы является наличие рекомендаций или нормативно- правовой базы, созданной или признанной соответствующими национальными органами власти (например, Министерством образования или другим соответствующим министерством или организацией). Они могут включать указания, нормативы или инструкции, в которых изложены положения о возможностях обучения детей младшего возраста.

113. В системах образования с обязательным образованием к уровню МСКО 0 относятся программы необязательного образования, разработанные для участия в них детей до начала обучения в системе обязательного образования, и соответствующие выше описанным критериям. В дополнение, в некоторых странах первый этап или цикл обязательного образования может быть отнесен к уровню МСКО 0, при условии соответствия критериям этого уровня. Однако начало обязательного образования не является достаточным критерием для отличия программы уровня MCKO 0 от программ уровня MCKO 1, несмотря на то, что подобное возможно в некоторых системах образования.

\section{C. Программы, охватывающие несколько уровней МСКО}

114. Классификация образовательных программ, охватывающих уровни МСКО 0 и 1, требует особого внимания. В системах образования, где часть образования детей младшего возраста включена в начальное образование, классифицировать как уровень МСКО 0 следует только те классы, этапы или циклы, которые соответствуют критериям, представленным в пункте 104. Те классы, этапы, циклы, которые соответствуют критериям, представленным в пункте 124, следует классифицировать как уровень МСКО 1.

115. Если применение критериев классификации не позволяет провести четкую грань между уровнями МСКО 0 и 1, то рекомендуется:

i) для программ, охватывающих уровни МСКО 0 и 1, организованных поэтапно, завершение этапа, близкое к 6 годам ребенка следует считать точкой перехода между уровнями МСКО 0 и 1; и

ii) для программ, охватывающих уровни МСКО 0 и 1 и не разделенных на этапы, классы, где обучаются дети до 6 лет, следует отнести к уровню МСКО 0, а остальные классы - к уровню MCKO 1.

\section{D. Дополнительные параметры}

116. Образовательные программы уровня МСКО 0 различают по одному параметру:

- Целевая возрастная группа (см. пункт 102).

\section{Е. Другие программы, включенные в уровень МСКО 0}

117. Уровень МСКО 0 включает программы для детей с особыми образовательными потребностями, соответствующие критериями, представленным в пункте 104, не зависимо от их возраста.

\section{F. Классификация образовательных программ уровня МСКО 0}

118. Код 010 используется для образовательных программ развития детей младшего возраста уровня МСКО 0, а код 020 - для программ дошкольного образования (см. пункт 102). Они не подразделяются на подкатегории по третьей цифре кода. 


\section{G. Классификация уровня полученного образования на уровнях MCKO 0 и 1}

119. При классификации уровня полученного образования уровень 0 (ниже начального образования) используется для тех, кто:

• никогда не посещал образовательную программу,

- посещал некоторую часть программ образования для детей младшего возраста (уровень МСКО 0),

- посещал некоторую часть программ начального образования, но не завершил успешно уровень MCKO 1 (с посещением или без посещения уровня МСKO 0).

Коды классификации для уровня полученного образования, относящиеся к дошкольному и начальному образованию, представлены в таблице 4. 


\section{УРОВЕНЬ МСКО 1 НАЧАЛЬНОЕ ОБРАЗОВАНИЕ}

\section{А. Основные характеристики}

120. Программы уровня МСКО 1, или «начальное образование», как правило, направлены на обучение основным навыкам чтения, письма и математики (т. е. грамотность и счёт) и на создание солидной основы для изучения и понимания основных областей знаний, для развития личности и социального развития и для подготовки к обучению на первом этапе среднего образования. Обучение направлено на получение образования на основном уровне сложности с минимальной специализацией, если таковая имеется.

121. Образовательная деятельность на уровне MCKO 1 (особенно в начальных классах уровня) зачастую организована по разделам, проектам или расширенным областям обучения, скорее, с применением комплексного подхода к обучению, чем с обучением по конкретным предметам. Как правило, преподавание ведет один учитель, который отвечает за группу учащихся и организует учебный процесс, хотя возможно присутствие и еще одного учителя, особенно для преподавания отдельных предметов или разделов программы.

122. Как правило, единственным требованием к поступлению на этом уровне является возраст. Поступающему, в большинстве случаев, должно быть не менее 5 лет и не более 7 лет в соответствии с типичным или установленным законом возрастом. Обычно данный уровень длится 6 лет, однако его продолжительность может варьироваться от четырех до семи лет. Обучение по программам начального образования обычно заканчивается в возрасте от 10 до 12 лет (см. пункты 132-134). По завершению программ начального образования дети могут продолжить образование на уровне MCKO 2 (первый этап среднего образования).

123. Программы, относящиеся к уровню МСКО 1, могут называться по-разному, например, начальное образование, элементарное или основное образование (этап 1/младшие классы, если система образования имеет одну программу, охватывающую уровни МСКО 1 и 2). В целях сопоставимости данных на международном уровне для обозначения уровня МСКО 1 используется термин «начальное образование».

\section{B. Критерии классификации}

124. Для определения начального образования важны следующие критерии:

\section{Основные критерии}

a) Систематическое обучение основным знаниям, навыкам и компетенций (см. пункт 125);

b) Типичный возраст поступления и продолжительность (см. пункт 122); и

с) Обучение, как правило, организованное одним учителем (см. пункт 126).

\section{Дополнительные критерии}

а) Часть обязательного образования (см. пункт 127).

125. Граница между уровнями МСКО 0 и 1 совпадет с точкой перехода в систему образования, где начинается систематическое преподавание и обучение чтению, письму и математики. Хотя до этого, некоторые программы МСКО уже могли дать определенные навыки чтения, письма и математики, дети еще прочно не овладели основными навыками в этих областях и поэтому эти программы в 
полной мере не соответствуют критериям, чтобы их можно было отнести к уровню МСКО 1. Переход от дошкольного к начальному образованию, как правило, отмечен поступлением в специально предназначенные, признанные государством, начальные учебные заведения или программы.

126. Как правило, один учитель несет ответственность за группу детей и обеспечивает учебный процесс, зачастую организуя его по разделам, проектам или расширенным областям обучения на основе комплексного подхода (особенно в первые годы начального образования). Однако в классе могут работать и другие учителя, особенно для проведения занятий по специализированным предметам. Учителя, преподающие на программах уровня МCKO 1, как правило, получают педагогическую подготовку по основным предметам. В противоположность этому, на программах уровня МСКО 2 могут преподавать несколько учителей-предметников, зачастую имеющих более углубленную подготовку по отдельным предметам.

127. Начало обучения на программах начального образования часто совпадает с началом обязательного образования, за исключением систем образования, где часть или все дошкольное образование уже является обязательным. По этой причине там, где обязательное образование закреплено законодательно, оно начинается с уровня МСКО 1 или ранее.

\section{С. Программы, охватывающие несколько уровней МСКо}

128. Классификация образовательных программ, охватывающих уровни МСКО 0 и 1 или 1 и 2, требует особого внимания. В системах образования, где начальное образование является частью образовательной программы, продолжительностью 8 лет и более, только те классы, этапы или циклы, которые соответствую критериям, представленным в пункте 124, следует отнести к уровню МСКО 1. Любые другие классы, этапы или циклы, соответствующие критериям, представленным в пункте 104, следует отнести к уровню МСКО 0, а те, которые соответствует критериям, представленным в пункте 143 - отнести к уровню МСКО 2.

129. Если применение критериев классификации не позволяет провести четкую грань между уровнями МСКО 0 и 1, дополнительные критерии для определения завершения уровня МСKО 0 и начала уровня МСКО 1 представлены в пункте 115.

130. Если применение критериев классификации не позволяет провести четкую грань между уровнями МСКО 1 и 2, рекомендуется следующее:

і) для программ, охватывающих уровни MCKO 1 и 2, организованных поэтапно, точкой перехода между уровнями МСКО 1 и 2 следует считать завершение этапа наиболее близкого к шести годам обучения после начала уровня МСKO 1; и

ii) для программ, охватывающих уровни МСКО 1 и 2 и не разделенных на этапы, только первые шесть лет обучения следует относить к уровню МСКО 1, а остальные годы относить к уровню МСКО 2 (см. пункт 149).

\section{D. Дополнительные параметры}

131. Отсутствуют.

\section{Е. Другие программы, включенные в уровень МСКО 1}

132. Уровень МСКО 1 включает программы для людей с особыми потребностями, если программа предоставляет систематическое образование и обучение, направленное на формирование основных навыков чтения, письма и математики, вне зависимости от возраста участника. 
133. Этот уровень также включает программы второго шанса или программы реинтеграции. Подобные образовательные программы обычно рассчитаны на тех:

i) кто бросил школу до завершения начального образования, позволяя им вернуться к обучению и завершить начальное образование; или

ii) кто завершил начальное образование, но желает обучаться по образовательной программе или получить профессию, которые еще не подтверждены соответствующим документом. Участники таких программ, как правило, старше целевой возрастной группы уровня МСКО 1 (но они не обязательно являются взрослыми).

134. К К уровню МСКО 1 также относятся программы по ликвидации неграмотности в рамках формального и неформального образования, схожие по сложности содержания с программами, классифицированными как программы начального образования и предназначенные для взрослых и подростков, старше типичного возраста учащихся уровня МСКО 1.

\section{F. Классификация образовательных программ уровня MCKO 1}

135. Все образовательные программы на уровне МСКО 1 имеют код 100. Категории и подкатегории, отличающиеся друг от друга второй или третьей цифрой, отсутствуют.

\section{G. Классификация уровня полученного образования на уровнях MCKO 0 и 1}

136. При кодировании уровня полученного образования, особое внимание следует уделить классификации тех лиц, которые посещали, но не завершили программы начального образования.

137. При классификации уровня полученного образования признанные квалификации программ уровня MCKO 2, считающиеся недостаточными для завершения или неполного завершения уровня МСKO 2, относятся к уровню МСКО 1 (например, программы продолжительностью менее двух лет на уровне МСКО 2 или программы, совокупная продолжительность которых менее восьми лет с начала обучения на уровне МСКО 1).

138. В таблице 4 представлены коды классификации уровня полученного образования, связанные с программами уровня МСКО 0 и 1 и квалификациями, относящимися к программам первого этапа среднего образования, которых не достаточно для того, чтобы считать уровень МСКО 2 завершенным или завершенным не полностью.

\section{Таблица 4. Коды классификации уровня полученного образования, связанные с уровнями МСКО 0-1 (МСК0-У)}

\begin{tabular}{|c|c|c|c|c|c|}
\hline \multicolumn{2}{|c|}{ Уровень МСКО-У } & \multicolumn{2}{|r|}{ Категория } & \multicolumn{2}{|r|}{ Подкатегория } \\
\hline 0 & $\begin{array}{l}\text { Ниже начального } \\
\text { образования }\end{array}$ & 01 & $\begin{array}{l}\text { Никогда не посещавшие } \\
\text { образовательную программу }\end{array}$ & 010 & $\begin{array}{l}\text { Никогда не посещавшие образовательную } \\
\text { программу }\end{array}$ \\
\hline & & 02 & $\begin{array}{l}\text { Некоторая часть образования детей } \\
\text { младшего возраста }\end{array}$ & 020 & $\begin{array}{l}\text { Некоторая часть образования детей } \\
\text { младшего возраста }\end{array}$ \\
\hline & & 03 & $\begin{array}{l}\text { Некоторая часть начального } \\
\text { образования (без завершения уровня) }\end{array}$ & 030 & $\begin{array}{l}\text { Некоторая часть начального образования } \\
\text { (без завершения уровня) }\end{array}$ \\
\hline 1 & $\begin{array}{l}\text { Начальное } \\
\text { образование }\end{array}$ & 10 & Начальное образование & 100 & $\begin{array}{l}\text { Включая признанное успешное завершение } \\
\text { первого этапа среднего образования, } \\
\text { недостаточное для завершения уровня или } \\
\text { неполного завершения уровня }\end{array}$ \\
\hline
\end{tabular}




\section{УРОВЕНЬ МСКО 2 ПЕРВЫЙ ЭТАП СРЕДНЕГО ОБРАЗОВАНИЯ}

\section{А. Основные характеристики}

139. Программы уровня МСКО 2, или программы «первого этапа среднего образования», как правило, основываются на учебных результатах уровня МСКО 1. Обычно цель образования заключается в том, чтобы заложить основы для обучения в течение всей жизни индивидуума и для развития личности, что может затем позволить образовательным системам расширять возможности для дальнейшего получения образования. Некоторые образовательные системы уже могут предложить программы профессионально-технического образования на уровне МСКО 2, формирующие навыки, востребованные на рынке труда.

140. Программы этого уровня обычно организованы по учебному плану, ориентированному на конкретные предметы с объяснением теоретических понятий по широкому кругу вопросов. Преподаватели, как правило, имеют педагогическую подготовку по отдельным дисциплинам, и чаще, чем на уровне МСКО 1, преподавание в классе ведется несколькими учителями, обладающими специализированными знаниями по преподаваемым предметам.

141. Уровень MCKO 2 начинается спустя четыре - семь лет обучения на уровне MCKO 1. Наиболее распространенная продолжительность уровня МСКО 1 - шесть лет. Обучение на уровне МСКО 2 начинается, как правило, в возрасте 10-13 лет (12 лет - наиболее распространенный возраст).

142. Программы, относящиеся к уровню MCKО 2, могут называться по-разному, например, средняя школа (первый этап/младшие классы, если существует одна программа, охватывающая уровни MCKO 2 и 3), младшая средняя школа, средняя школа или неполная средняя школа. Если программа охватывает уровни МСКО 1 и 2, часто используются термины elementary school (общее начальное образование) или основная школа (второй этап/старшие классы). В целях сопоставимости данных на международном уровне для обозначения уровня МСКО 2 используется термин «первый этап среднего образования».

\section{B. Критерии классификации}

143. Для определения первого этапа среднего образования важны следующие критерии:

\section{Основные критерии}

а) Переход к более предметно-ориентированному обучению (см. пункт 144);

b) Требования к поступлению (см. пункт 145); и

с) Совокупная продолжительность с начала обучения на уровне MCKO 1 (см. пункт 146).

\section{Дополнительные критерии}

а) Типичный возраст поступления (см. пункт 141);

b) Преподавание учителями-предметниками и квалификации учителей (см. пункт 147); и

с) Связь с обязательным образованием (см. пункт 148).

144. Граница между уровнем МСКО 1 и уровнем МСКО 2 совпадает с точкой перехода в системы образования, где особое значение придается предметно-ориентированному обучению. 
145. Этот уровень требует завершения уровня МСКО 1 или способности осваивать содержание уровня МСKO 2 посредством сочетания уже полученного образования с жизненным и трудовым опытом. В некоторых странах для поступления на некоторые или на все программы уровня МСКО 2 может потребоваться успешное завершение уровня МСКО 1 или наличие проходного балла.

146. Обучение на уровне МСКО 2 заканчивается спустя 8-11 лет с начала уровня MCKO 1, и его совокупная продолжительность в большинстве случаев составляет 9 лет. В конце уровня МСКО 2 возраст учащихся, как правило, составляет 14-16 лет (чаще всего 15 лет).

147. По сравнению с уровнем МСКО 1 квалификации преподавателей уровня МСКО 2 могут отличаться. Помимо педагогической квалификации на уровне МСКО 2 они также имеют квалификацию по одному или более специальным предметам. Кроме того, организация учебного процесса может отличаться от уровня МСКО 1, поскольку чаще в одном классе преподают несколько учителей, специализирующихся в одной или нескольких областях.

148. Во многих системах образования, где обязательное образование закреплено законодательно, завершение первого этапа среднего образования совпадает с завершением обязательного (общего) образования.

\section{С. Программы, охватывающие несколько уровней МСКо}

149. Классификация образовательных программ, охватывающих уровни МСКО 1 и 2 или уровни 2 и 3, требует особого внимания. Только те классы, этапы, циклы, которые соответствуют критериям, представленным в пункте 143, следует отнести к уровню МСКО 2. Те классы, этапы, циклы, которые соответствуют критериям, представленным в пункте 124, следует отнести к уровню МСКО 1, а те, которые соответствуют критериям, представленным в пункте 166, следует отнести к уровню МСКО 3.

150. Если применение критериев классификации не позволяет провести четкую грань между уровнями МСKO 1 и 2, для определения завершения уровня МСКО 1 и начала уровня МСКО 2 рекомендуется использовать критерии, представленные в пункте 130.

151. Если применение критериев классификации не позволяет провести четкую грань между уровнями МСКО 2 и 3, рекомендуется следующее:

i) для программ, охватывающих уровни MCKO 2 и 3, организованных поэтапно, точкой перехода между уровнями МСКО 2 и 3 следует считать завершение этапа, наиболее близкого к девяти годам после начала обучения на уровне МСКО 1; или

ii) для программ, охватывающих уровни МСКО 2 и 3 и не разделенных на этапы, только классы между завершением уровня МСКО 1 и до завершения девяти лет обучения после начала уровня МСКО 1 следует относить к уровню МСКО 2, а остальные года относить к уровню МСКО 3 (см. пункт 171).

\section{D. Дополнительные параметры}

152. Программы уровня МСКО 2 различаются по двум параметрам:

- Ориентация программы (см. пункт 153);

- Завершение уровня и доступ к более высокому уровню МСКО (см. пункт 154). 


\section{Ориентация программы}

153. В пунктах 55 и 54 даны определения двух категорий ориентации:

- Общее образование; и

- Профессионально-техническое образование.

\section{Завершение уровня и доступ к более высокому уровню МСКО}

154. Для уровня MCKO 2 выделены следующие четыре подкатегории завершения уровня и доступа:

i) Уровень МСКО 2 не завершен (и поэтому без прямого доступа к более высоким уровням МСКО): короткие конечные программы (или последовательность программ) продолжительностью менее двух лет на уровне MCKO 2 или те, которые завершаются менее чем через восемь лет совокупной продолжительности обучения с начала уровня МСКО 1. Они не дают доступа к уровню МСКО 3. Успешное завершение таких программ не засчитывается как завершение уровня MCKO 2.

ii) Неполное завершение уровня МСКО 2 без прямого доступа к более высоким уровням МСКО: программы, продолжительностью не менее двух лет на уровне MCKO 2 и совокупная продолжительность которых составляет не менее восьми лет с начала обучения на уровне MCKO 1, и которые являются частью последовательности программ уровня MCKO 2, но не являются последними в последовательности на этом уровне. Эти программы не дают прямого доступа к уровню МСКО 3. Успешное завершение таких программ рассматривается лишь как неполное завершение уровня (поскольку только заключительная программа в последовательности программ вероятнее всего предоставит доступ к уровню МСКО 3).

iii) Завершение уровня МСКО 2 без прямого доступа к более высоким уровням МСКО: программы продолжительностью не менее двух лет на уровне MCKO 2, которые завершаются не менее чем через восемь лет совокупной продолжительности после начала обучения на уровне МСКО 1, но которые не дают доступа к уровню МСКО 3. Хотя эти программы считаются конечными, успешное их завершение рассматривается как завершение уровня МСКО 2.

iv) Завершение уровня МСКО 2 с прямым доступом к более высоким уровням: любые программы, дающие прямой доступ к уровню МСКО 3, вне зависимости от их продолжительности в рамках уровня или их совокупной продолжительности с начала обучения на уровне MCKO 1.

\section{Е. Другие программы, включенные в уровень МСКО 2}

155. Уровень МСКО 2 включает программы для людей с особыми потребностями, которые разработаны для организации основного учебного процесса, начавшегося на уровне МСКО 1 и/или для формирования навыков, позволяющих найти работу.

156. Этот уровень также включает программы «второго шанса» первого этапа среднего образования или программы реинтеграции. Подобные образовательные программы обычно направлены на тех, кто:

i) покинул школу после завершения начального образования, но до завершения первого этапа среднего образования, позволяя им вернуться к обучению и завершить первый этап среднего образования; или

ii) завершил первый этап среднего образования, но желает обучаться по образовательной программе или получить профессию, которые еще не подтверждены соответствующим документом.

Участники этих программ обычно старше целевой возрастной группы уровня МСКО 2. 
157. Этот уровень также включает образовательные программы для взрослых, которые равнозначны по сложности содержания образованию программам, уже классифицированным как программы этого уровня.

\section{F. Классификация образовательных программ уровня MCKO 2}

158. Применение двух дополнительных параметров позволяет использовать категории для определения ориентации программ, а подкатегории для определения завершения уровня и доступа к следующему более высокому уровню МСКО. Коды для программ первого этапа среднего образования приведены в Таблице 5.

\section{Таблица 5. Коды классификации образовательных программ уровня МСКО 2 (МСКО-П)}

\begin{tabular}{|c|c|c|c|}
\hline \multicolumn{2}{|r|}{$\begin{array}{l}\text { Категория } \\
\text { (Ориентация) }\end{array}$} & \multicolumn{2}{|r|}{$\begin{array}{c}\text { Подкатегория } \\
\text { (Завершение уровня и доступ к более высокому уровню МСКО) }\end{array}$} \\
\hline \multirow[t]{4}{*}{24} & \multirow{4}{*}{$\begin{array}{l}\text { Первый этап } \\
\text { общего среднего } \\
\text { образования }\end{array}$} & 241 & $\begin{array}{l}\text { Недостаточно для завершения уровня или неполного завершения, без прямого доступа ко } \\
\text { второму этапу среднего образования }\end{array}$ \\
\hline & & 242 & $\begin{array}{l}\text { Достаточно для неполного завершения уровня, без прямого доступа ко второму этапу } \\
\text { среднего образования }\end{array}$ \\
\hline & & 243 & $\begin{array}{l}\text { Достаточно для завершения уровня, без прямого доступа ко второму этапу среднего } \\
\text { образования }\end{array}$ \\
\hline & & 244 & $\begin{array}{l}\text { Достаточно для завершения уровня с прямым доступом ко второму этапу среднего } \\
\text { образования }\end{array}$ \\
\hline \multirow[t]{4}{*}{25} & \multirow{4}{*}{$\begin{array}{l}\text { Первый этап } \\
\text { среднего } \\
\text { профессионально- } \\
\text { технического } \\
\text { образования }\end{array}$} & 251 & $\begin{array}{l}\text { Недостаточно для завершения уровня или неполного завершения уровня, без прямого } \\
\text { доступа ко второму этапу среднего образования }\end{array}$ \\
\hline & & 252 & $\begin{array}{l}\text { Достаточно для неполного завершения уровня, без прямого доступа ко второму этапу } \\
\text { среднего образования }\end{array}$ \\
\hline & & 253 & $\begin{array}{l}\text { Достаточно для завершения уровня, без прямого доступа ко второму этапу среднего } \\
\text { образования }\end{array}$ \\
\hline & & 254 & $\begin{array}{l}\text { Достаточно для завершения уровня, с прямым доступом ко второму этапу среднего } \\
\text { образования }\end{array}$ \\
\hline
\end{tabular}

\section{G. Классификация уровня полученного образования на уровне MCKO 2}

159. При классификации уровня образования, признанные квалификации программ уровня MCKO 2, не считающиеся достаточными для завершения или неполного завершения уровня MCKO 2, относятся к уровню МСКО 1 (см. таблицу 4).

160. Равным образом, признанные квалификации программ уровня МСКО 3, недостаточные для завершения или неполного завершения уровня МСКО 3, относятся к уровню МСКО 2.

161. Коды классификации уровня полученного образования, относящиеся к первому этапу среднего образования и квалификациям программ второго этапа среднего образования, недостаточные для того, чтобы считать уровень завершенным или не полностью завершенным, представлены в таблице 6. 
Таблица 6. Коды классификации уровня полученного образования, связанные с уровнем МСКО 2 (МСКО-У)

\begin{tabular}{|c|c|c|c|}
\hline \multicolumn{2}{|r|}{$\begin{array}{l}\text { Категория } \\
\text { (Ориентация) }\end{array}$} & \multicolumn{2}{|r|}{$\begin{array}{c}\text { Подкатегория } \\
\text { (Завершение уровня и доступ к более высокому уровню МСКО) }\end{array}$} \\
\hline 10 & $\begin{array}{l}\text { Начальное } \\
\text { образование }\end{array}$ & 100 & $\begin{array}{l}\text { Признанное успешное завершение программ первого этапа среднего образования, } \\
\text { недостаточное для завершения уровня или неполного завершения уровня }\end{array}$ \\
\hline \multirow[t]{3}{*}{24} & \multirow{3}{*}{$\begin{array}{l}\text { Первый этап } \\
\text { общего среднего } \\
\text { образования }\end{array}$} & 242 & $\begin{array}{l}\text { Неполное завершение уровня, без прямого доступа ко второму этапу среднего } \\
\text { образования }\end{array}$ \\
\hline & & 243 & Завершение уровня без прямого доступа ко второй ступени среднего образования \\
\hline & & 244 & Завершение уровня с прямым доступом ко второму этапу среднего образования \\
\hline \multirow[t]{3}{*}{25} & \multirow{3}{*}{$\begin{array}{l}\text { Первый этап среднего } \\
\text { профессио-нально- } \\
\text { технического } \\
\text { образования }\end{array}$} & 252 & $\begin{array}{l}\text { Неполное завершение уровня, без прямого доступа ко второму этапу среднего } \\
\text { образования }\end{array}$ \\
\hline & & 253 & Завершение уровня без прямого доступа ко второму этапу среднего образования \\
\hline & & 254 & Завершение уровня с прямым доступом ко второму этапу среднего образования ${ }^{1}$ \\
\hline
\end{tabular}




\section{УРОВЕНЬ МСКО $З$ ВТОРОЙ ЭТАП СРЕДНЕГО ОБРАЗОВАНИЯ}

\section{А. Основные характеристики}

162. Программы МСКО 3 или «второй этап среднего образования», как правило, рассчитаны на завершение среднего образования, дающего подготовку к третичному образованию или обучению навыкам, позволяющим найти работу, либо обеспечивающего и то и другое.

163. Программы этого уровня предлагают учащимся более разнообразное, специализированное и углубленное изучение предметов, чем программы уровня МСКО 2. Они более дифференцированы и предоставляют более широкий выбор возможностей и направлений. Учителя обычно имеют более высокую квалификацию по предметам или областям специализации, которые преподают, особенно в старших классах.

164. Уровень МСКО 3 начинается после 8-11 лет обучения после начала обучения на уровне МСКО 1. Как правило, учащиеся переходят на этот уровень в возрасте 14-16 лет. Программы уровня МСКО 3 обычно заканчиваются спустя 12-13 лет после начала обучения на уровне МСКО 1 (примерно в возрасте 17 или 18 лет), наиболее распространенная совокупная продолжительность - 12 лет. Однако окончание второй ступени среднего образования в образовательных системах варьируется и обычно составляет 11-13 лет с начала обучения на уровне МСКО 1.

165. Программы, относящиеся к уровню МСКО 3, могут называться по-разному, например, средняя школа (второй этап/старшие классы), старшая средняя школа или (полная) средняя школа. В целях сопоставимости данных на международном уровне для обозначения уровня МСКО 3 используется термин "второй этап среднего образования".

\section{B. Критерии классификации}

166. Для определения второго этапа среднего образования важны следующие критерии:

\section{Основные критерии}

а) Второй/заключительный этап общего и профессионально-технического образования (см. пункт 167);

b) Требования к поступлению (см. пункт 168); и

c) Совокупная продолжительность с начала обучения на уровне MCKO 1 (см. пункт 164).

\section{Дополнительные критерии}

а) Более дифференцированные программы с более широким выбором возможностей и направлений (см. пункт 169); и

b) Квалификации преподавателей (см. пункт 170).

167. Программы второго/заключительного этапа среднего образования могут быть отнесены к программам общего образования или профессионально-технического образования уровня МСКО 3. Некоторые из этих программ дают прямой доступ к уровню МСKO 4 и/или уровням 5, 6 или 7. При определении точек перехода с одного уровня на другой, следует обеспечивать соответствие между общим и профессионально-техническим направлениями. 
168. Уровень МСКО 3 требует завершения первого этапа среднего образования (уровень МСКО 2) или способности изучать содержание уровня МСКО 3 через сочетание как уже полученного образования, так и жизненного и трудового опыта. Для поступления на некоторые или на все программы уровня МСКО 3 может требоваться наличие квалификации уровня МСKO 2 или определенного проходного балла.

169. Переход с уровня МСКО 2 на уровень МСКО 3 совпадает с точкой перехода в системах образования, где учащимся предлагаются программы с более разнообразным, специализированным и углубленным изучением отдельных предметов или областей. Как правило, программы более дифференцированы, с более широким выбором возможностей и направлений.

170. По сравнению с уровнем МСКО 2 уровень квалификации преподавателей может отличаться на уровне МСКО 3. В дополнение к педагогической подготовке преподаватели могут быть более квалифицированными по предметам, которые они преподают.

\section{С. Программы, охватывающие несколько уровней МСКо}

171. Классификация образовательных программ, охватывающих уровни МСКО 2 и 3 или уровни МСКО 3 и 5, требует особого внимания. Только те классы, этапы или циклы, которые соответствуют критериям, представленным в пункте 166, следует отнести к уровню МСКО 3. Те классы, этапы или циклы, которые соответствуют критериям, представленным в пункте 143, следует отнести к уровню МСКО 2 , а те, которые соответствуют критериям, представленным в пункте 211, следует отнести к уровню MCKO 5.

172. Если применение критериев классификации не позволяет провести четкую грань между уровнями MCKO 2 и 3, для определения завершения уровня МСKO 2 и начала уровня МСKO 3 рекомендуется использовать критерии, представленные в пункте 151.

173. Если теоретическая продолжительность программ профессионально-технического образования уровня МСКО 3 на два или более года превышает теоретическую продолжительность общей программы уровня МСКО 3 в той же системе образования, эту программу следует рассматривать как охватывающую второй этап среднего образования (уровень МСKО 3) и послесреднее нетретичное образование (уровень МСКО 4) или короткий цикл третичного образования (уровень МСКО 5). В зависимости от сложности содержания, классы, этапы или циклы, выходящие за рамки общей программы уровня МСКО 3, следует отнести к уровням МСКО 4 или 5.

\section{D. Дополнительные параметры}

174. Образовательные программы для уровня МСКО 3 различаются по двум параметрам:

- Ориентация программы (см. пункт 175); и

- Завершение уровня и доступ к более высокому уровню МСКО (см. пункт 176).

\section{Ориентация программы}

175. В пунктах 55 и 54 даны определения двух категорий ориентации:

- Общее образование; и

- Профессионально-техническое образование. 


\section{Завершение уровня и доступ к более высокому уровню МСКО}

176. Для уровня МСКО 3 выделены следующие четыре подкатегории завершения уровня и доступа:

i) Уровень МСКО 3 не завершен (и поэтому без прямого доступа к первым программам третичного образования на уровнях МСКО 5, 6 и 7): короткие конечные программы (или последовательность программ) продолжительностью менее двух лет на уровне МСКО 3 или те программы, которые завершаются менее чем через 11 лет совокупной продолжительности обучения с начала уровня MCKO 1. Они не дают прямого доступа к уровням MCKO 5, 6 и 7. Успешное завершение таких программ не засчитывается как завершение уровня МСКО 3. Следует отметить, что эти программы также не дают прямого доступа к уровню МСКО 4.

ii) Неполное завершение уровня МСКО 3 без прямого доступа к первым программам третичного образования на уровнях МСКО 5, 6 и 7: программы продолжительностью не менее 2 лет на данном уровне и совокупная продолжительность которых составляет не менее 11 лет с начала обучения на уровне МСКО 1, и которые являются частью последовательности программ уровня MCKO 3, но не являются последними в последовательности на этом уровне. Эти программы не предоставляют прямого доступа к уровням MCKO 5, 6 и 7. Успешное завершение таких программ рассматривается лишь как неполное завершение уровня (поскольку только заключительная программа в последовательности программ вероятнее всего предоставит доступ к третичному образованию на уровнях МСKO 5, 6 or 7). Следует отметить, что эти программы также не дают прямого доступа к уровню МСКО 4.

iii) Завершение уровня МСКО 3 без прямого доступа к первым программам третичного образования на уровнях MCKO 5, 6 и 7: программы, продолжительностью обучения не менее двух лет на данном уровне и завершающиеся после не менее 11 лет совокупной продолжительности с начала обучения на уровне МСКО 1. Эти программы могут быть конечными или могут давать прямой доступ к уровню МСKO 4. Успешное завершение таких программ рассматривается как успешное завершение уровня МСКО 3.

iv) Завершение уровня МСКО 3 с прямым доступом к первым программам третичного образования на уровнях MCKO 5, 6 и 7: любые программы, дающие прямой доступ к первым программам третичного образования на уровнях MCKO 5, 6 и 7, вне зависимости от их продолжительности в рамках уровня или их совокупной продолжительности с начала обучения на уровне МСКО 1. Эти программы могут также давать прямой доступ к уровню МСКО 4.

\section{Е. Другие программы, включенные в уровень МСКО 3}

177. Уровень МСКО 3 включает программы для людей с особыми потребностями, которые равнозначны по сложности содержания образованию, программам, уже классифицированным как программы уровня МСКО 3.

178. Этот уровень может включать некоторые программы профессионально-технического образования второго цикла в тех случаях, когда точки перехода в конце второго цикла соответствуют точкам перехода между уровнями в других, главным образом, общих направлениях, предлагаемых системой.

179. Этот уровень также включает программы «второго шанса» второго этапа среднего образования или программы реинтеграции. Подобные образовательные программы обычно рассчитаны на тех, кто:

i) покинул школу до завершения второго этапа среднего образования, позволяя им вернуться к обучению в образовательной системе и завершить второй этап среднего образования; или 
ii) завершил второй этап среднего образования, но желает обучаться по образовательной программе или получить профессию, которые еще не подтверждены соответствующим документом.

Участники этих программ обычно старше целевой возрастной группы уровня МСКО 3.

180. Этот уровень также включает программы образования для взрослых, которые равнозначны по сложности содержания образованию, программам, уже классифицированным как программы этого уровня.

\section{F. Классификация образовательных программ уровня MCKO 3}

181. Применение двух дополнительных параметров позволяет использовать категории для определения ориентации программ, а подкатегории для определения завершения уровня и доступа к следующему более высокому уровню МСКО. В системах образования разных стран существуют и широко распространены не все сочетания ориентаций, завершения и доступа. Коды программ второго этапа среднего образования представлены в таблице 7.

\section{Таблица 7. Коды классификации образовательных программ уровня МСКО 3 (МСКО-П)}

\begin{tabular}{|c|c|c|c|}
\hline \multicolumn{2}{|r|}{$\begin{array}{l}\text { Категория } \\
\text { (Ориентация) }\end{array}$} & \multicolumn{2}{|r|}{$\begin{array}{c}\text { Подкатегория } \\
\text { (Завершение уровня и доступ к более высокому уровню МСКО) }\end{array}$} \\
\hline \multirow[t]{4}{*}{34} & \multirow{4}{*}{$\begin{array}{l}\text { Второй этап } \\
\text { общего среднего } \\
\text { образования }\end{array}$} & 341 & $\begin{array}{l}\text { Недостаточно для завершения уровня или неполного завершения уровня, без прямого } \\
\text { доступа к послесреднему нетретичному образованию или третичному образованию }\end{array}$ \\
\hline & & 342 & $\begin{array}{l}\text { Достаточно для неполного завершения, без прямого доступа к послесреднему } \\
\text { нетретичному образованию или третичному образованию }\end{array}$ \\
\hline & & 343 & $\begin{array}{l}\text { Достаточно для завершения уровня, без прямого доступа к третичному образованию (но } \\
\text { возможен прямой доступ к послесреднему нетретичному образованию) }\end{array}$ \\
\hline & & 344 & $\begin{array}{l}\text { Достаточно для завершения уровня, с прямым доступом к третичному образованию } \\
\text { (также возможен прямой доступ к послесреднему нетретичному образованию) }\end{array}$ \\
\hline \multirow[t]{4}{*}{35} & \multirow{4}{*}{$\begin{array}{l}\text { Второй этап } \\
\text { профессионально- } \\
\text { технического } \\
\text { образования }\end{array}$} & 351 & $\begin{array}{l}\text { Недостаточно для завершения уровня или неполного завершения уровня, без прямого } \\
\text { доступа к послесреднему нетретичному образованию или третичному образованию }\end{array}$ \\
\hline & & 352 & $\begin{array}{l}\text { Достаточно для неполного завершения, без прямого доступа к послесреднему } \\
\text { нетретичному образованию или третичному образованию }\end{array}$ \\
\hline & & 353 & $\begin{array}{l}\text { Достаточно для завершения уровня, без прямого доступа к третичному образованию (но } \\
\text { возможен прямой доступ к послесреднему нетретичному образованию) }\end{array}$ \\
\hline & & 354 & $\begin{array}{l}\text { Достаточно для завершения уровня, с прямым доступом к третичному образованию } \\
\text { (также возможен прямой доступ к послесреднему нетретичному образованию) }\end{array}$ \\
\hline
\end{tabular}




\section{G. Классификация уровня полученного образования на уровне MCKO 3}

182. При классификации уровня полученного образования признанные квалификации программ уровня MCKO 3, не считающиеся достаточными для завершения уровня МСKO 3, относятся к уровню MCKO 2.

183. Равным образом, признанные квалификации программ уровня МСКО 4 , недостаточные для завершения уровня МСKO 4, относятся к уровню МСКО 3.

184. Коды классификации уровня полученного образования, относящиеся к программам второго этапа среднего образования и квалификациями, представлены в таблице 8.

\section{Таблица 8. Коды классификации уровня полученного образования на уровне МСКО 3 (МСКО-У)}

\begin{tabular}{|c|c|c|c|}
\hline \multicolumn{2}{|r|}{$\begin{array}{l}\text { Категория } \\
\text { (Ориентация) }\end{array}$} & \multicolumn{2}{|r|}{$\begin{array}{c}\text { Подкатегория } \\
\text { (Завершение уровня и доступ к более высокому уровню МСКО) }\end{array}$} \\
\hline 24 & $\begin{array}{l}\text { Первый этап общего } \\
\text { среднего образования }\end{array}$ & 244 & $\begin{array}{l}\text { Признанное успешное завершение второго этапа программ общего среднего } \\
\text { образования недостаточное для завершения уровня или неполного завершения } \\
\text { уровня }\end{array}$ \\
\hline 25 & $\begin{array}{l}\text { Первый этап среднего } \\
\text { профессионально- } \\
\text { технического } \\
\text { образования }\end{array}$ & 254 & $\begin{array}{l}\text { Признанное успешное завершение второго этапа программ профессионально- } \\
\text { технического образования недостаточное для завершения уровня или неполного } \\
\text { завершения уровня }\end{array}$ \\
\hline \multirow[t]{3}{*}{34} & \multirow[t]{3}{*}{$\begin{array}{l}\text { Второй этап общего } \\
\text { среднего образования }\end{array}$} & 342 & $\begin{array}{l}\text { Неполное завершение уровня без прямого доступа к послесреднему нетретичному } \\
\text { образованию или третичному образованию }\end{array}$ \\
\hline & & 343 & $\begin{array}{l}\text { Завершение уровня без прямого доступа к третичному образованию (но возможен } \\
\text { прямой доступ к послесреднему нетретичному образованию) }\end{array}$ \\
\hline & & 344 & $\begin{array}{l}\text { Завершение уровня с прямым доступом к третичному образованию1 (возможен } \\
\text { прямой доступ к послесреднему нетретичному образованию) }\end{array}$ \\
\hline \multirow[t]{3}{*}{35} & \multirow{3}{*}{$\begin{array}{l}\text { Второй этап среднего } \\
\text { профессионально- } \\
\text { технического } \\
\text { образования }\end{array}$} & 352 & $\begin{array}{l}\text { Неполное завершение уровня без прямого доступа к послесреднему нетретичному } \\
\text { образованию или третичному образованию }\end{array}$ \\
\hline & & 353 & $\begin{array}{l}\text { Завершение уровня без прямого доступа к третичному образованию (но возможен } \\
\text { прямой доступ к послесреднему нетретичному образованию) }\end{array}$ \\
\hline & & 354 & $\begin{array}{l}\text { Завершение уровня с прямым доступом к третичному образованию' (возможен } \\
\text { прямой доступ к послесреднему нетретичному образованию) }\end{array}$ \\
\hline
\end{tabular}




\section{УРОВЕНЬ МСКО 4 ПОСЛЕСРЕДНЕЕ НЕТРЕТИЧНОЕ ОБРАЗОВАНИЕ}

\section{A. Основные характеристики}

185. Послесреднее нетретичное образование направлено на приобретение учебного опыта учащимися на базе среднего образования, на подготовку к выходу на рынок труда, а также на получение третичного образования. Оно направлено на индивидуальное приобретение знаний, навыков и компетенций ниже параметров третичного образования высокого уровня сложности. Программы уровня МСКО 4 или «послесреднего нетретичного образования», как правило, разрабатываются для обучения тех, кто закончил уровень МСКО 3 с квалификациями нетретичного образования, необходимыми для продвижения вперед к третичному образованию или для трудоустройства, если квалификация уровня МСКО 3 не дает такого доступа. Например, выпускники общих программ уровня МСКО 3 могут выбрать получение профессионально-технической квалификации нетретичного образования; или выпускники программ профессионально-технического образования уровня МСКО 3 решат повысить свой уровень квалификации или получить дальнейшую специализацию. Содержание программ уровня МСКО 4 не достаточно сложное по сравнению с третичным образованием, хотя оно явно относится к послесреднему образованию.

186. Для поступления на программы уровня МСКО 4 требуется завершение программ уровня MCKO 3. Однако эти требования к поступлению могут быть ниже, чем требования к поступлению на программы третичного образования уровней MCKO 5, 6 и 7.

187. Обычно программы, относящиеся к этому уровню, рассчитаны на прямой выход на рынок труда. В некоторых системах образования на этом уровне существуют программы общего характера. Такие программы, рассчитаны на учащихся, завершивших уровень МСКО 3, но желающих повысить шансы на поступление на программы третичного образования.

188. Программы, относящиеся к уровню МСКО 4, могут называться по-разному, например, диплом техника, начальное профессиональное образование или préparation aux carrières administratives. В целях сопоставимости данных на международном уровне для обозначения уровня MCKO 4 используется термин «послесреднее нетретичное образование».

\section{B. Критерии классификации}

189. Для определения послесреднего нетретичного образования важны следующие критерии:

\section{Основные критерии}

а) Ориентация (см. пункт 190);

b) Сложность содержания выше, чем на уровне MCKO 3, и ниже уровня третичного образования (см. пункт 191); и

с) Требования к поступлению (см. пункт 186).

\section{Дополнительные критерии}

Отсутствуют.

190. Программы уровня МСКО 4 не рассматриваются как третичное образование и, как правило, имеют профессионально-техническую направленность или являются конечными программами, готовящими к рынку труда. В некоторых системах образования на этом уровне могут быть программы общего характера. Программы, предназначенные для пересмотра содержания программ 
уровня MCKO 3, например, с целью подготовки учащихся к вступительным экзаменам на программы третичного образования, следует включить в уровень МСКО 3.

191. Программы уровня МСКО 4 часто служат скорее для расширения знаний, чем для углубления знаний, навыков и компетенций участников, закончивших программу уровня МСКО 3. Программы часто незначительно сложнее, чем программы уровня МСКО 3, но их содержание, как правило, более специализировано или детализировано, чем на втором этапе среднего образования. Программы явно менее сложны, чем на уровне третичного образования, и могут преподаваться в различных учебных заведениях, а не только в тех, которые относятся к учебным заведениям послесреднего невысшего образования.

\section{С. Программы, охватывающие несколько уровней МСКО}

192. Не применимо.

\section{D. Дополнительные параметры}

193. Программы образования уровня MCKO 4 различаются по двум параметрам:

- Ориентация программы (см. пункт 194); и

- Уровень завершения и доступ к более высокому уровню MCKO (см. nункт 195).

\section{Ориентация программы}

194. В пунктах 55 и 54 даны определения двух категорий ориентации:

- Общее образование; и

- Профессионально-техническое образование.

\section{Завершение уровня и доступ к более высокому уровню МСКО}

195. Для уровня МСКО 4 выделены следующие три подкатегории завершения уровня и доступа:

- Уровень MCКО 4 не завершен: модули или этапы программ, которые слишком коротки для завершения уровня. Они не дают доступа к программам первого этапа третичного образования на уровнях MCKO 5, 6 или 7. Успешное завершение таких модулей или этапов не засчитывается как завершение уровня МСKO 4.

- Завершение уровня МСКО 4 без прямого доступа к первому этапу программ третичного образования на уровнях MCKO 5, 6 или 7: программы предназначенные, прежде всего, для прямого выхода на рынок труда.

- Завершение уровня МСКО 4 с прямым доступом к первому этапу программ третичного образования на уровнях MCKO 5, 6 или 7: программы предназначенные, прежде всего, для расширенного доступа к третичного образованию.

\section{Е. Другие программы уровня MCKO 4}

196. Этот уровень включает программы образования для взрослых, которые равнозначны по сложности содержания образованию, программам, уже классифицированным как программы этого уровня. 


\section{F. Классификация образовательных программ на уровне MСКО 4}

197. Применение двух дополнительных параметров позволяет использовать категории для определения ориентации программ, а подкатегории для определения завершения уровня и доступа. В системах образования существуют и широко распространены не все сочетания категорий и подкатегорий. Классификация послесреднего нетретичного образования представлена в таблице 9.

\section{Таблица 9. Коды классификации образовательных программ на уровне МСКО 4 (МСКО-П)}

\begin{tabular}{|c|l|c|l|}
\hline \multicolumn{2}{|c|}{$\begin{array}{l}\text { Kaтегория } \\
\text { (Ориентация) }\end{array}$} & \multicolumn{2}{|c|}{ (Уровень заверпения и доступ к более высокому уровню МСКо) } \\
\hline 44 & $\begin{array}{l}\text { Послесреднее } \\
\text { нетретичное } \\
\text { общее } \\
\text { образование }\end{array}$ & 441 & Недостаточно для завершения уровня, без прямого доступа к третичному образованию \\
\cline { 2 - 4 } & 443 & Достаточно для завершения уровня, без прямого доступа к третичному образованию \\
\cline { 2 - 4 } & $\begin{array}{l}\text { Послесреднее } \\
\text { нетретичное } \\
\text { профессионально- } \\
\text { техническое } \\
\text { образование }\end{array}$ & 451 & Достаточно для завершения уровня, с прямым доступом к третичному образованию \\
\cline { 2 - 4 } & 454 & Досостаточно для завершения уровня, без прямого доступа к третичному образованию \\
\cline { 2 - 4 }
\end{tabular}

\section{G. Классификация уровня полученного образования на уровне MCКО 4}

198. При классификации уровня полученного образования признанные промежуточные квалификации успешно завершенного этапа программ уровня MCKO 5, не считающиеся достаточными для завершения уровня МСКО 5, относятся к уровню МСКО 4.

199. Коды классификации уровня полученного образования, относящиеся к квалификациям послесреднего нетретичного образования, представлены в таблице 10.

\section{Таблица 10. Коды классификации уровня полученного образования на уровне MСКО 4 (МСКО-У)}

\begin{tabular}{|c|l|c|l|}
\hline \multicolumn{2}{|c|}{$\begin{array}{l}\text { Kатегория } \\
\text { (Ориентачия) }\end{array}$} & \multicolumn{2}{|c|}{$\begin{array}{l}\text { Подканегория } \\
\text { (Уровень заверпения и достул к более высокому уровню МСКо) }\end{array}$} \\
\hline 34 & $\begin{array}{l}\text { Второй этап общего среднего } \\
\text { образования }\end{array}$ & 344 & $\begin{array}{l}\text { Признанное успешное завершение этапа общих программ послесреднего } \\
\text { нетретичного образования, недостаточное для завершения уровня }\end{array}$ \\
\hline 35 & $\begin{array}{l}\text { Второй этап среднего } \\
\text { профессионально-технического } \\
\text { образования }\end{array}$ & 354 & $\begin{array}{l}\text { Признанное успешное завершение этапа профессионально-технических } \\
\text { программ послесреднего нетретичного образования, недостаточное для } \\
\text { завершения уровня }\end{array}$ \\
\hline 44 & $\begin{array}{l}\text { Послесреднее нетретичное } \\
\text { образование }\end{array}$ & 443 & Завершение уровня без прямого доступа к третичному образованию \\
\cline { 2 - 4 } & 444 & Завершение уровня с прямым доступом к третичному образованию' \\
\hline 45 & $\begin{array}{l}\text { Послесреднее нетретичное } \\
\text { профессионально-техническое } \\
\text { образование }\end{array}$ & 453 & Завершение уровня без прямого доступа к третичному образованию \\
\cline { 2 - 4 } & 454 & Завершение уровня с прямым доступом к третичному образованию' \\
\hline 1. Вкючая признанное успешное завершение программы или этапа программы в рамках короткого цикла третичного образования, недостаточное для завершения \\
уровня.
\end{tabular}




\section{ТРЕТИЧНОЕ ОБРАЗОВАНИЕ}

200. Третичное образование основывается на среднем образовании, организуя учебную деятельность в рамках специализированных областей образования. Оно направлено на обучение на более высоком уровне сложности и специализации. Третичное образование не только включает то, что обычно понимается как академическое образование, но также и углубленное профессиональное образование. Оно охватывает уровни MCKO 5, 6, 7 и 8, которые называются, соответственно, коротким циклом третичного образования, бакалавриатом или его эквивалентом, магистратурой или её эквивалентом и докторантурой или её эквивалентом. Содержание программ третичного образования более сложное и углубленное, чем на более низких уровнях МСКО.

201. Первые программы уровней MCKO 5, 6 или 7 требуют успешного завершения программ уровня MCKO 3, дающего прямой доступ к первым программам третичного образования. Доступ к этим программам также возможен с уровня МСКО 4. В дополнение к требованиям к квалификациям, поступление на образовательные программы этих уровней может зависеть от выбора предмета и/ или оценок, полученных на уровнях МСКО 3 или 4. В дальнейшем, возможно, потребуется успешно сдать вступительные экзамены.

202. В рамках третичного образования образовательная программа всегда относится к тому же уровню, что и уровень квалификации, полученной после успешного завершения программы (если только программа частично не относится к уровню MCKO 3, см. пункт 173). Поэтому в отличие от уровней МСKO 0, 1, 2 и 3, понятие программ, охватывающих уровни МСКО, в третичном образовании не применимо.

203. Традиционно существует четкая иерархия между квалификациями, присваиваемыми по окончании программ третичного образования. Однако, в отличие от программ уровней МСКО 1, 2 и 3, национальные программы уровней МСKO 5, 6 и 7 могут существовать скорее параллельно, а не путем последовательного надстраивания одного уровня МСКО над другим. После завершения программ уровней МСKO 3 и 4 может предоставляться доступ к ряду программ уровней MCKO 5, 6 и 7, в зависимости от доступности этих программ в конкретной системе образования и от дополнительных требований к поступлению, которые также могут определяться отдельно. К этим программам относятся:

- программы короткого цикла третичного образования на уровне МСКО 5 (не менее двух лет);

- программы первой степени бакалавриата или его эквивалент на уровне MCKO 6 (от трех до четырех лет);

- долгосрочные программы первой степени бакалавриата или его эквивалент на уровне МСКО 6 (более четырех лет); или

- долгосрочные программы первой степени магистратуры или её эквивалент на уровне МСКО 7 (не менее пяти лет).

204. Переход между программами на уровне третичного образования не всегда четко определен, и существует возможность комбинировать программы и переводить кредиты с одной программы на другую. В некоторых случаях кредиты, полученные на ранее завершенных образовательных программах, также могут быть зачтены при завершении программы на более высоком уровне MCKO. Например, кредиты, полученные на программе уровня МСКО 5, могут уменьшить требуемое количество кредитов или продолжительность обучения для завершения программы на уровне 6. В некоторых системах участники программ могут быть переведены на образовательные программы 
уровня МСKO 6 после завершения программ уровня МСKO 5, что может сократить время, требуемое для завершения программы уровня МСКО 6. Другие могут непосредственно с уровня МСКО 3 поступить на программы уровней МСКО 6 и 7. Во многих системах образования большинство учащихся должны сначала завершить уровень МСKO 6, чтобы получить доступ к уровню МСКО 7.

205. Для поступления на уровень МСКО 8 обычно требуется успешное завершение уровня MCKO 7.

206. Категории программ третичного образования и пути перехода с одной программы на другую представлены в Схеме 1.

\section{Схема 1. Пути перехода третичного образования в рамках MCKO}

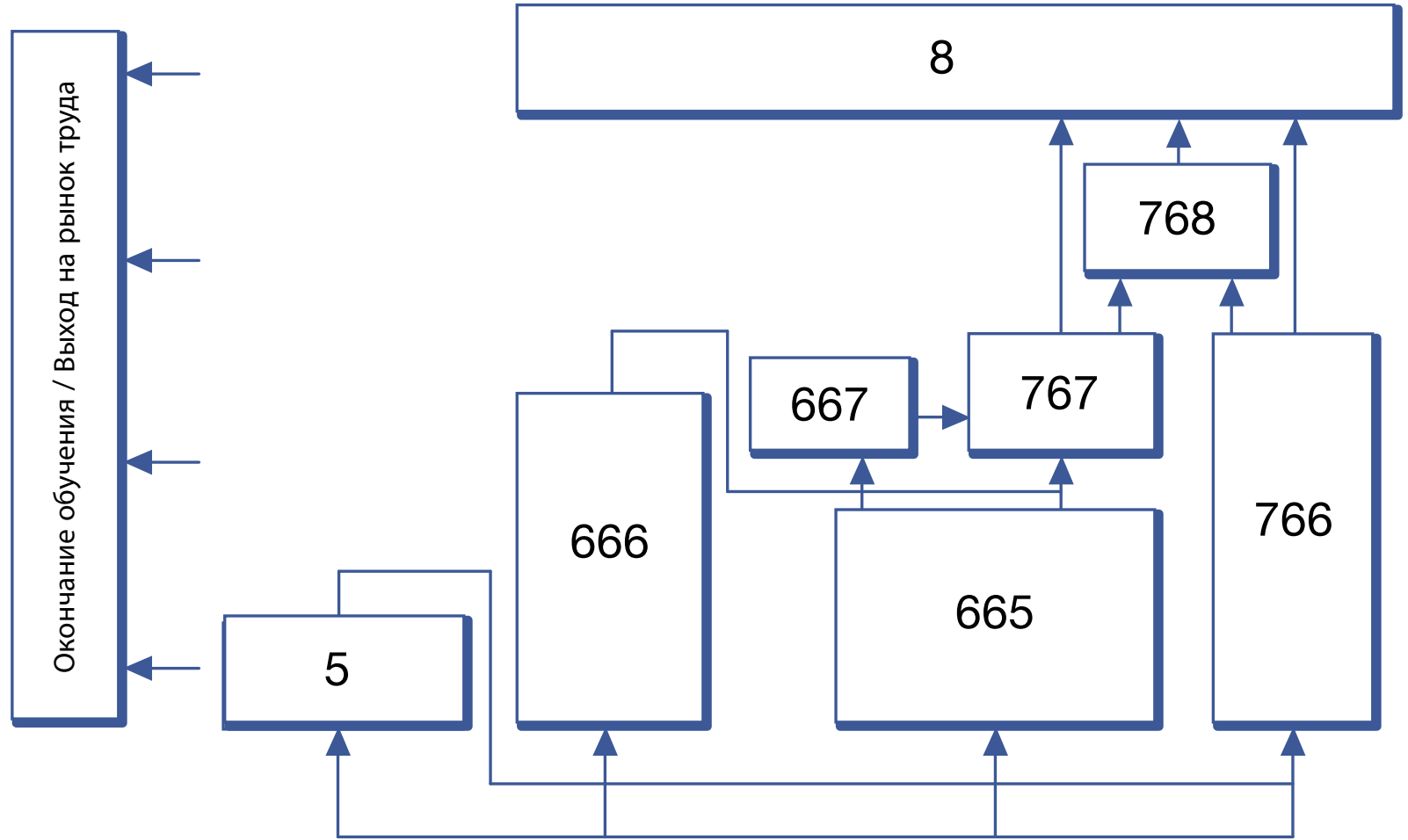

Завершение уровней МСКО 3 и 4 с прямым доступом к первым программам третичного образования на уровнях MCKO 5, 6 и 7 


\section{УРОВЕНЬ МСКО 5 КОРОТКИЙ ЦИКЛ ТРЕТИЧНОГО ОБРАЗОВАНИЯ}

\section{А. Основные характеристики}

207. Программы уровня МСКО 5. или «короткий цикл третичного образования» часто предназначены для предоставления участникам профессиональных знаний и развития профессиональных навыков и компетенций. Как правило, они связаны с практикой, профессиональной ориентацией и подготовкой учащихся к выходу на рынок труда. Однако эти программы также могут открывать путь к другим программам третичного образования. Академические программы третичного образования, которые ниже программ бакалавриата или равнозначных им, также относятся к уровню MCKO 5.

208. Для поступления на программы уровня МСКО 5 требуется успешное завершение уровней MCKO 3 и 4 с доступом к третичному образованию. Программы уровня МСКО 5 сложнее по содержанию, чем программы уровней МСКО 3 и 4, но они короче и обычно содержат меньше теоретического материала, чем программы уровня МСКО 6.

209. Хотя программы уровня МСКО 5 обычно предназначены для подготовки к трудовой деятельности, они могут дать кредиты для перехода на программы уровней МСКО 6 или 7. После завершения этих программ уровня МСКО 5 в некоторых системах образования участники могут продолжить обучение на программах уровня МСКО 6 (бакалавриат или его эквивалент) или на долгосрочных программах первой степени уровня МСКО 7 (магистратура или её эквивалент).

210. Программы, относящиеся к уровню MCKO 5, могут называться по-разному, например, (высшее) техническое образование, community college education, technician or advanced/higher vocational training, associate degree или bac + 2. В целях сопоставимости данных на международном уровне для обозначения уровня МСКО 5 используется термин «короткий цикл третичного образования».

\section{B. Критерии классификации}

211. Для определения короткого цикла третичного образования важны следующие критерии:

\section{Основные критерии}

a) Содержание программ короткого цикла третичного образования (см. пункт 212);

b) Требования к поступлению (см. пункт 208); и

с) Минимальная продолжительность уровня (см. пункт 213).

\section{Дополнительные критерии}

a) Институциональная точка перехода (см. пункт 214); и

b) Обычная продолжительность уровня (см. пункт 213).

212. Уровень МСКО 5 охватывает самый нижний уровень третичного образования. Содержание программ этого уровня более сложное, чем содержание программ среднего образования (уровень MCKO 3) или послесреднего нетретичного образования (уровень МСКО 4), но менее сложное, чем уровень МСКО 6 (бакалавриат или его эквивалент).

213. Минимальная продолжительность уровня МСКО 5 - два года и обычно, но не во всех случаях, длится менее трех лет. Для систем образования с модульными программами, квалификации присваиваются по мере получения кредитов, требуется обучение, сопоставимое по временным затратам и интенсивности.

214. Точка перехода от учебного заведения нетретичного образования к учебному заведению третичного образования помогает определить границу между второй ступенью среднего образования (уровень 
MCKO 3), послесредним нетретичным образованием (уровень МСКО 4) и третичным образованием. Программы уровня МСКО 5 и программы уровней МСКО 6, 7 и 8 часто предоставляются различными учебными заведениями.

\section{C. Программы, охватывающие несколько уровней МСКо}

215. Классификация образовательных программ, охватывающих уровни МСКО 3 и 5, требует особого внимания. Классы, этапы или циклы, которые соответствуют критериям, представленным в пункте 211, следует отнести к уровню МСКО 5. Те классы, этапы и циклы, которые соответствуют критериям, представленным в пункте 166, следует отнести к уровню МСКО 3. Если применение критериев классификации не позволяет четко определить границу между уровнями МСКО 3 и 5 , критерии для определения завершения уровня МСКО 3 и начала уровня МСКО 5 представлены в пункте 173.

\section{D. Дополнительные параметры}

216. Образовательные программы уровня МСКО 5 различаются по двум параметрам:

- Ориентация программы (см. пункт 217); и

- Завершение уровня (см. пункт 218).

\section{Ориентация программы}

217. Определения следующих двух категорий ориентации предоставлены в пунктах 55 и 54:

- Общее образование; и

- Профессиональное образование.

Когда определения для академических и профессиональных программ будут разработаны, они будут использоваться для категорий ориентации на уровне MCKO 5 вместо общего и профессионального образования.

\section{Завершение уровня}

218. Для уровня МСКО выделены две категории завершения уровня MCKO 5:

- Уровень МСКО 5 не завершен: продолжительность этапа (или программы) уровня МСКО 5 менее двух лет недостаточна для завершения уровня МСKO 5.

- Завершение уровня МСКО 5: продолжительность программы уровня МСКО 5 два года и более достаточна для завершения уровня МСКО 5.

\section{Е. Другие программы, включенные в уровень МСКО 5}

219. Этот уровень включает программы образования для взрослых или программы непрерывного образования, которые равнозначны по сложности содержания образованию, программам, уже классифицированным как программы этого уровня.

\section{F. Классификация образовательных программ на уровне MCK0 5}

220. Для формирования отчетности применение двух дополнительных параметров позволяет использовать категории для определения ориентации программ, а подкатегории для определения завершения уровня. Коды, которые следует использовать для уровня МСКО 5, представлены в таблице 11. 


\section{Таблица 11. Коды классификации образовательных программ уровня МСКО 5 (МСК0-П)}

\begin{tabular}{|c|c|c|c|}
\hline \multicolumn{2}{|r|}{$\begin{array}{l}\text { Категория } \\
\text { (Ориентация) }\end{array}$} & \multicolumn{2}{|r|}{$\begin{array}{c}\text { Подкатегория } \\
\text { (Завершение уровня) }\end{array}$} \\
\hline \multirow[t]{2}{*}{54} & \multirow{2}{*}{$\begin{array}{l}\text { Короткий цикл общего третичного } \\
\text { образования' }\end{array}$} & 541 & Недостаточно для завершения уровня \\
\hline & & 544 & Достаточно для завершения уровня \\
\hline \multirow[t]{2}{*}{55} & \multirow{2}{*}{$\begin{array}{l}\text { Короткий цикл профессионального } \\
\text { третичного образования }{ }^{1}\end{array}$} & 551 & Недостаточно для завершения уровня \\
\hline & & 554 & Достаточно для завершения уровня \\
\hline
\end{tabular}

\section{G. Классификация уровня полученного образования уровня MCKO 5}

221. При классификации уровня полученного образования признанные промежуточные квалификации успешного завершения этапа (или программы) уровня МСKO 5, не считающиеся достаточными для завершения уровня MCKO 5, относятся к уровню MCKO 4. Участие в программах без признанного успешного завершения уровня МСКО 5 не учитывается для определения уровней полученного образования.

222. При оценке уровня полученного образования признанные промежуточные квалификации, полученные в результате успешного завершения этапа программ (предшествующих первой степени), не рассматриваются как достаточные для завершения уровня MCKO 6, а относятся к уровню MCKO 5.

223. Коды классификации уровня полученного образования, относящиеся к уровню МСКО 5 , представлены в таблице 12.

\section{Таблица 12. Коды классификации уровня полученного образования, связанные с уровнем МСКО 5 (МСКО-У)}

\begin{tabular}{|c|c|c|c|}
\hline \multicolumn{2}{|r|}{ Категория (Ориентация) } & \multicolumn{2}{|r|}{ Подкатегория (Завершение уровня) } \\
\hline 44 & Послесреднее нетретичное общее образование & 444 & $\begin{array}{l}\text { Признанное успешное завершение общей }{ }^{1} \text { программы } \\
\text { (или этапа) короткого цикла третичного образования } \\
\text { недостаточно для завершения уровня }\end{array}$ \\
\hline 45 & $\begin{array}{l}\text { Послесреднее профессионально-техническое } \\
\text { нетретичное образование }\end{array}$ & 454 & $\begin{array}{l}\text { Признанное успешное завершение профессиональной } \\
\text { программы (или этапа) короткого цикла третичного } \\
\text { образования недостаточно для завершения уровня }\end{array}$ \\
\hline 54 & Короткий цикл общего третичного образования ${ }^{1}$ & 540 & Далее не определено ${ }^{2}$ \\
\hline 55 & $\begin{array}{l}\text { Короткий цикл профессионального третичного } \\
\text { образования' }\end{array}$ & 550 & Далее не определено² \\
\hline 56 & $\begin{array}{l}\text { Короткий цикл третичного образования } \\
\text { ориентация неопределена }\end{array}$ & 560 & Далее не определено ${ }^{2}$ \\
\hline \multicolumn{4}{|c|}{$\begin{array}{l}\text { 1. Для применения на уровне МСКО } 5 \text { в связи с отсутствием согласованных на международном уровне определений для академической и профессиональной } \\
\text { ориентации на третичном уровне. }\end{array}$} \\
\hline \multicolumn{4}{|c|}{$\begin{array}{l}\text { 2. Включая признанное успешное завершение программы короткого цикла третичного образования достаточное для завершения уровня МСКО } 5 \text { или завершение } \\
\text { программы или этапа программы на уровне бакалавриата или его эквивалента недостаточное для завершения уровня МСКО } 6 .\end{array}$} \\
\hline \multicolumn{4}{|c|}{$\begin{array}{l}\text { 3. Для применения на уровне МСКО } 6 \text { в отсутствии согласованных на международном уровне определений для академической и профессиональной ориентации на } \\
\text { третичном уровне. }\end{array}$} \\
\hline
\end{tabular}




\section{УРОВЕНЬ МСКО 6 БАКАЛАВРИАТ ИЛИ ЕГО ЭКВИВАЛЕНТ}

\section{А. Основные характеристики}

224. Программы уровня МСКО 6, или «бакалавриат или его эквивалент» часто предназначены для получения участниками промежуточных академических и/или профессиональных знаний, навыков и компетенций, ведущих к присвоению первой степени или равнозначной квалификации. Программы этого уровня, как правило, имеют теоретическую основу, но могут включать практические компоненты и характеризуются высоким уровнем исследований и/или лучшую профессиональную практику. Традиционно они преподаются в университетах и равнозначных учебных заведениях третичного образования.

225. Обучение на этом уровне часто проходит в форме лекций преподавателей, имеющих, как правило, квалификацию МСКО 7 и 8 или более глубокий опыт работы в этой области. Программы этого уровня не обязательно требуют завершения работы над научно-исследовательским проектом или диссертацией, но если подобная работа ведется, то она менее углубленная и менее независимая или более направляемая, чем на уровнях МСКО 7 и 8.

226. Обычно для поступления на программы этого уровня требуется успешное завершение программ уровней МСКО 3 или 4, дающих доступ к третичному образованию. Поступление может зависеть от выбора предметов и/или оценок, полученных на уровнях МСКО 3 и/или 4. Кроме того, возможно, потребуется сдать вступительные экзамены. Поступление или перевод на уровень МСКО 6 также иногда возможны после успешного завершения уровня МСКО 5. После завершения программ уровня МСКО 6 учащиеся могут продолжить образование на уровне МСКО 7 (магистратура или её эквивалент), хотя не все программы уровня МСКО 6 дают доступ к уровню МСКО 7. Программы уровня МСКО 6 обычно не дают прямого доступа к программам уровня МСКО 8 (докторантура или её эквивалент).

227. Программы, относящиеся к уровню МСКО 6, могут называться по-разному, например, программы бакалавриата, licence или первый цикл университетского образования. Однако важно отметить, что программы с названиями, схожими с названием «бакалавриат», следует включать в уровень МСКО 6, только если они соответствуют критериям, представленным в пункте 228. В целях сопоставимости данных на международном уровне для обозначения уровня МСКО 6 используется термин «бакалавриат или его эквивалент».

\section{B. Критерии классификации}

228. Для определения бакалавриата или его эквивалента важны следующие критерии:

\section{Основные критерии}
а) Теоретическая и/или профессиональная основа содержания (см. пункт 224);
b) Требования к поступлению (см. пункт 226);
с) Минимальная совокупная продолжительность (первая степень) программы (см. nункт 229); и
d) Положение в национальной структуре степеней и квалификаций (см. пункт 230).

\section{Дополнительные критерии}

а) Квалификация персонала (см. пункт 231); и

b) Нет прямого доступа к программам уровня MCKO 8 (см. пункт 226). 
229. Продолжительность программ первой степени на этом уровне, как правило, составляет от трех до четырех лет очного обучения на уровне третичного образования. Для систем, где степени присваиваются по количеству накопленных кредитов, требуется обучение, сопоставимое по временным затратам и интенсивности.

230. Программы этого уровня, как правило, ведут к присвоению первых степеней и равнозначных квалификаций третичного образования (хотя до поступления на программу уровня МСКО 6 учащиеся могут получить квалификацию уровня МСКО 5). Они могут включать практический компонент и/или занятия на базе предприятий и организаций, а также и теоретические занятия. Долгосрочные программы первой степени, продолжительностью более четырех лет включены в этот уровень, если они по сложности содержания равнозначны программам бакалавриата. Кроме того, программы, ведущие ко второй или последующей степени, могут быть включены в уровень МСКО 6, если они по сложности содержания равнозначны программам уже классифицированным на этом уровне в той же системе образования и соответствуют другим основным критериям. Продолжительность обучения в рамках программ второй или последующих степеней, как правило, на этом уровне от одного до двух лет и они обычно профессионально ориентированы, предлагая большую специализацию, чем обучение в рамках первой степени, однако, по содержанию обучение не значительно более сложное. Основательная подготовка диссертации на программах уровня МСКО 6 не обязательна.

231. В тех случаях, где это уместно, требование квалификаций уровня МСКО 8 для некоторых преподавателей может быть хорошим косвенным критерием для образовательных программ данного уровня в тех системах, где такое требование существует. Это позволяет отличить программы уровня МСKO 5 от программ уровня МСKO 6.

\section{С. Программы, охватывающие несколько уровней МСКо}

232. Не применимо.

\section{D. Дополнительные параметры}

233. Программы уровня МСКО 6 различают по двум параметрам:

- Ориентация программы (см. пункт 234); и

- Продолжительность программы и положение в национальной структуре степеней и квалификаций (см. пункт 235).

\section{Ориентация программы}

234. Представлены две категории ориентации:

- Академическое образование; и

- Профессиональное образование.

\section{Продолжительность программы и положение в национальной структуре степеней и квалификаций}

235. Для уровня МСКО 6 выделены следующие четыре подкатегории продолжительности программы и положения в национальной структуре степеней и квалификаций:

- Этап (или программа) в рамках первой степени на уровне бакалавриата или его эквивалента с совокупной теоретической продолжительностью менее трех лет (на уровне третичного образования) и поэтому недостаточный для завершения уровня МСКО 6; 
- Программа первой степени на уровне бакалавриата или его эквивалента с совокупной теоретической продолжительностью от трех до четырех лет (на уровне третичного образования);

- Долгосрочная программа первой степени на уровне бакалавриата или его эквивалента с совокупной теоретической продолжительностью более четырех лет (на уровне третичного образования); и

- Программы второй или последующей степени на уровне бакалавриата или его эквивалента (с последующим успешным завершением программы бакалавриата или его эквивалента).

\section{E. Программы, также включенные в МСК0 6}

236. Этот уровень включает программы для взрослых или программы непрерывного образования, которые равнозначны по сложности содержания образованию, программам, уже классифицированным как программы этого уровня.

\section{F. Классификация образовательных программ уровня МСКО 6}

237. Для формирования отчетности применение двух дополнительных параметров позволяет использовать категории для определения ориентации программ, а подкатегории для определения продолжительность программы и её положения в национальной структуре степеней и квалификаций. Коды, которые следует применять для уровня МСКО 6, представлены в таблице 13.

\section{Таблица 13. Коды классификации образовательных программ уровня МСКО 6 (МСКО-П)}

\begin{tabular}{|c|c|c|c|}
\hline & $\begin{array}{l}\text { Категория } \\
\text { (Ориентация) }\end{array}$ & $\begin{array}{c}\text { Подкатегория } \\
\text { (Продолжительность/ } \\
\text { положение) }\end{array}$ & Описание \\
\hline \multirow[t]{4}{*}{64} & \multirow{4}{*}{$\begin{array}{l}\text { Бакалавриат или } \\
\text { его эквивалент, } \\
\text { академическое } \\
\text { образование }\end{array}$} & 641 & Недостаточно для завершения уровня \\
\hline & & 645 & Первая степень (3-4 года) \\
\hline & & 646 & Долгосрочная программа первой степени (более 4 лет) \\
\hline & & 647 & $\begin{array}{l}\text { Вторая или последующая степень (с последующим успешным } \\
\text { завершением программы бакалавра или его эквивалента) }\end{array}$ \\
\hline \multirow[t]{4}{*}{65} & \multirow{4}{*}{$\begin{array}{l}\text { Бакалавриат или } \\
\text { его эквивалент, } \\
\text { профессиональное } \\
\text { образование }\end{array}$} & 651 & Недостаточно для завершения уровня \\
\hline & & 655 & Первая степень (3-4 года) \\
\hline & & 656 & Долгосрочная программа первой степени (более 4 лет) \\
\hline & & 657 & $\begin{array}{l}\text { Вторая или последующая степень (с последующим успешным } \\
\text { завершением программы бакалавра или его эквивалента) }\end{array}$ \\
\hline \multirow[t]{4}{*}{66} & \multirow{4}{*}{$\begin{array}{l}66 \text { Бакалавриат } \\
\text { или его эквивалент, } \\
\text { ориентация не } \\
\text { определена' }\end{array}$} & 661 & Недостаточно для завершения уровня \\
\hline & & 665 & Первая степень (3-4 года) \\
\hline & & 666 & Долгосрочная программа первой степени (более 4 лет) \\
\hline & & 667 & $\begin{array}{l}\text { Вторая или последующая степень (с последующим успешным } \\
\text { завершением программы бакалавриата или его эквивалента) }\end{array}$ \\
\hline
\end{tabular}




\section{G. К Кассификация уровня полученного образования на уровне MCKO 6}

238. При классификации уровня полученного образования, признанные промежуточные квалификации успешного завершения этапов программ (предшествующих первой степени), не считающиеся достаточными для завершения уровня МСKO 6, относятся к уровню MCKO 5. Участие в программах без признанного успешного завершения первой программы уровня МСКО 6 не учитывается для определения уровней полученного образования.

239. При классификации уровня полученного образования признанные промежуточные квалификации, полученные в результате успешного завершения этапов первой программы уровня МСКО 7 (на магистратуре или её эквивалента - либо на долгосрочной программе первой степени, или второй степени после программы бакалавриата), которые недостаточны для завершения уровня МСКО 7 и относятся к уровню МСКО 6.

240. Коды классификации уровня полученного образования, относящиеся к уровню МСКО 6, представлены в таблице 14.

\section{Таблица 14. Коды классификации уровня полученного образования на уровне МСКО 6 (МСКО-У)}

\begin{tabular}{|c|c|c|c|}
\hline \multicolumn{2}{|r|}{ Категория (Ориентация) } & Подкатегория & Описание \\
\hline 54 & Короткий цикл общего третичного образования & 540 & Далее не определено' \\
\hline 55 & Короткий цикл профессионального третичного образования & 550 & Далее не определено' \\
\hline 56 & Короткий цикл третичного образования, ориентация неопределена² & 560 & Далее не определено' \\
\hline 64 & Бакалавриат или его эквивалент, академическое образование & 640 & Далее не определено ${ }^{3}$ \\
\hline 65 & Бакалавриат или его эквивалент, профессиональное образование & 650 & Далее не определено ${ }^{3}$ \\
\hline 66 & 66 Бакалавриат или его эквивалент, ориентация не определена² & 660 & Далее не определено ${ }^{3}$ \\
\hline \multicolumn{4}{|c|}{$\begin{array}{l}\text { 2. Для применения на уровне МСКО } 6 \text { и } 7 \text { в отсутствии согласованных на международном уровне определений программ и квалификаций для академической и } \\
\text { профессиональной ориентации на третичном уровне. }\end{array}$} \\
\hline \multicolumn{4}{|c|}{$\begin{array}{l}\text { 3. Включая признанное успешное завершение программы уровня бакалавриата или его эквивалента достаточное для завершения уровня МСК0 6, или программы или } \\
\text { этапа программы на уровне магистратуры или её эквивалента, недостаточное для завершения уровня МСКо } 7 .\end{array}$} \\
\hline
\end{tabular}




\section{УРОВЕНЬ МСКО 7 МАГИСТРАТУРА ИЛИ ЕЁ ЭКВИВАЛЕНТ}

\section{А. Основные характеристики}

241. Программы уровня МСКО 7, или «магистратура или её эквивалент», часто предназначены для предоставления участникам расширенных академических и/или профессиональных знаний, развития навыков и компетенций, ведущих к присвоению второй степени или равнозначной квалификации. Программы этого уровня могут иметь существенную исследовательскую составляющую, но еще не ведут к присвоению квалификации доктора наук. Как правило, программы этого уровня имеют теоретическую основу, но могут включать практический компонент и характеризуются высоким уровнем исследований или лучшей профессиональной практикой. Традиционно они преподаются в университетах или аналогичных учебных заведениях третичного образования.

242. Обучение на этом уровне часто проходит в форме лекций преподавателей, как правило, имеющих квалификацию МСКО 7 или 8. Программы этого уровня могут включать завершение работы над научноисследовательским проектом или диссертацией на более продвинутом уровне, чем тот, что ожидается от участников на уровне MCKO 6, и на менее продвинутом уровне, чем тот, что ожидается на уровне МСКО 8.

243. Обычно для поступления на программы уровня MCKO 7, подготавливающие ко второй или последующей степени, требуется успешное завершение программ уровней МСКО 6 или 7. В случае долгосрочных программ, которые готовят к первой степени, равнозначной степени магистра, для поступления требуется успешное завершение программ уровней МСКО 3 или 4, дающих доступ к третичному образованию. Поступление на обучение на таких программах может зависеть от выбора предмета и/или от оценок, полученных на уровнях МСКО 3 и/или 4. В дополнение, возможно, потребуется успешно сдать вступительные экзамены. Программы уровня МСКО 7 значительно более сложные по содержанию, чем программы уровня МСКО 6 и традиционно более специализированные. После завершения уровня возможно продолжение образования на уровне МСКО 8 (уровень докторантуры), хотя не все программы уровня МСКО 7 дают прямой доступ к уровню МСКО 8.

244. Программы, относящиеся к уровню MCKO 7, могут называться по-разному, например, программы магистра или magister. Однако важно отметить, что программы со схожим названием «магистр» следует включать в уровень МСКО 7, только если они соответствуют критериям, описанным в пункте 245. В целях сопоставимости данных на международном уровне для обозначения уровня МСКО 7 используется термин «магистратура или её эквивалент».

\section{B. Критерии классификации}

245. Для определения магистратуры или её эквивалента важны следующие критерии:

\section{Основные критерии}

а) Теоретическая и/или профессиональная основа содержания (см. пункт 241);

b) Положение в национальной структуре степеней и квалификаций (см. пункты 246 и 247); и

c) Требования к поступлению (см. пункт 243).

\section{Дополнительные критерии}

а) Минимальная совокупная продолжительность долгосрочных программ первой степени (см. пункт 247); и

b) Прямой доступ к программам уровня МСКО 8 (см. пункт 249). 
246. Программы этого уровня обычно готовят ко второй/последующей степени, следующей за первой степенью программ уровня МСКО 6 или 7. Равнозначные квалификации, такие как профессиональные квалификации аспирантов, также относятся к уровню МСКО 7, если они уже не отнесены к уровню МСКО 6 (см. пункт 230).

247. Программы продолжительностью не менее пяти лет, готовящие к первой степени/квалификации, также относятся к этому уровню, если по сложности содержания они равнозначны программам уровня магистратуры. Такие программы предполагают основательную работу над диссертацией. В этом случае присвоенная степень/квалификация дает прямой доступ к уровню МСКО 8 или программе, равнозначной программе второй или последующей степени, уже отнесенной к уровню МСКО 7. Узкоспециализированное профессиональное обучение, имеющее подобную или большую совокупную продолжительность на уровне третичного образования (например, медицина, стоматология, ветеринария и в некоторых случаях юриспруденция или инженерное дело), равнозначно по широте охвата и глубине содержания, хотя, как правило, без подготовки к диссертации, также рассматривается в рамках этого уровня.

248. Программы второй и последующей степеней на этом уровне, как правило, длятся 1-4 года очного обучения. В системах образования, где степени присваиваются по количеству накопленных кредитов, требуется обучение, сопоставимое по временным затратам и интенсивности. Совокупная продолжительность обучения на уровне третичного образования составляет обычно от пяти до восьми лет и даже больше.

249. Программы третичного образования, дающие прямой доступ к уровню МСКО 8, обычно относятся к уровню МСКО 7. Тем не менее, не все программы уровня МСКО 7 дают прямой доступ к уровню MCKO 8.

\section{С. Программы, охватывающие несколько уровней МСКо}

250. Не применимо.

\section{D. Дополнительные параметры}

251. Образовательные программы уровня МСКО 7 различают по двум параметрам:

- Ориентация программы (см. пункт 252); и

- Положение в национальной структуре степеней и квалификаций (см. пункт 253).

\section{Ориентация программы}

252. Представлены две категории ориентации:

- Академическое образование; и

- Профессиональное образование.

\section{Положение в национальной структуре степеней и квалификаций}

253. Для уровня МСКО 7 выделены следующие четыре категории положения в национальной структуре степеней и квалификаций:

- Этап (или программа) в рамках первой степени на уровне магистратуры или её эквивалента с совокупной теоретической продолжительностью (на уровне третичного образования) менее пяти лет и поэтому недостаточный для завершения уровня МСКО 7; 
- Долгосрочная программа первой степени на уровне магистратуры или её эквивалента с совокупной теоретической продолжительностью (на уровне третичного образования) не менее пяти лет (что не требует предварительного получения третичного образования);

- Программа второй и последующей степени на уровне магистратуры или её эквивалента (следующая за успешным завершением программы бакалавриата или его эквивалента); и

- Программа второй и последующей степени на уровне магистратуры или её эквивалент (следующая за успешным завершением другой программы магистратуры или её эквивалента).

\section{Е. Другие программы, включенные в уровень МСКО 7}

254. К уровню МСКО 7 относятся программы, ведущие к присвоению исследовательских квалификаций, предназначенных исключительно для подготовки участников к проведению самостоятельных исследований, но уровень этих исследований ниже, уровня тех, что проводятся на уровне степени доктора наук. Эти программы часто будут соответствовать многим из аналогичных критериев, присущих программам уровня МСКО 8, хотя продолжительность их обычно меньше (совокупная продолжительность с начала обучения на уровнях третичного образования от пяти до шести лет). Как правило, они не имеют той степени самостоятельности, которая требуется от соискателей продвинутой исследовательской квалификации и участники программ этого уровня готовятся к поступлению на программы уровня МСКО 8. В рамках этого уровня они классифицируются в зависимости от их положения в национальной структуре степеней и квалификаций.

\section{F. Классификация образовательных программ на уровне MCKO 7}

255. Для формирования отчетности применение двух дополнительных параметров позволяет использовать категории для определения ориентации программ, а подкатегории для определения положения программы в национальной структуре степеней и квалификаций. Коды, которые следует применять для уровня МСКО 7, представлены в таблице 15.

\section{G. К Классификация уровня полученного образования на уровне MCKO 7}

256. При классификации уровня полученного образования признанные промежуточные квалификации успешного завершения этапов (или программ) в рамках первой степени на уровне магистратуры или её эквивалента, не считающиеся достаточными для завершения уровня МСКО 7, относятся к уровню МСКО 6. Участие в программах без признанного успешного завершения любой программы первой степени на уровне МСКО 7 или второй, или последующей степени на уровне МСKО 7, следующей за успешным завершение программы бакалавриата или равнозначной ей программы, не учитывается для определения уровней полученного образования.

257. При оценке уровня полученного образования признанные промежуточные квалификации, полученные в результате успешного завершения этапов (или программ) на уровне докторантуры или её эквивалента, но недостаточные для завершения уровня МСКО 8, относятся к уровню MСКО 7.

258. Коды классификации уровня полученного образования, относящиеся к уровню МСКО 7, представлены в таблице 16. 


\section{Таблица 15. Коды классификации образовательных программ уровня МСКО 7 (МСК0-П)}

\begin{tabular}{|c|c|c|c|}
\hline \multicolumn{2}{|r|}{$\begin{array}{l}\text { Категория } \\
\text { (Ориентация) }\end{array}$} & $\begin{array}{l}\text { Подкатегория } \\
\text { (Положение) }\end{array}$ & Описание \\
\hline \multirow[t]{4}{*}{74} & \multirow{4}{*}{$\begin{array}{l}\text { Магистратура или } \\
\text { её эквивалент, } \\
\text { академическое } \\
\text { образование }\end{array}$} & 741 & Недостаточно для завершения уровня \\
\hline & & 746 & Долгосрочная первая степень (не менее 5 лет) \\
\hline & & 747 & $\begin{array}{l}\text { Вторая или последующая степень (следующая за успешным завершением } \\
\text { программы бакалавриата или равнозначной ей программы) }\end{array}$ \\
\hline & & 748 & $\begin{array}{l}\text { Вторая или последующая степень (следующая за успешным завершением } \\
\text { программы магистратуры или равнозначной ей программы) }\end{array}$ \\
\hline \multirow[t]{4}{*}{75} & \multirow{4}{*}{$\begin{array}{l}\text { Магистратура или } \\
\text { её эквивалент, } \\
\text { профессиональное } \\
\text { образование }\end{array}$} & 751 & Недостаточно для завершения уровня \\
\hline & & 756 & долгосрочная первая степень (не менее 5 лет) \\
\hline & & 757 & $\begin{array}{l}\text { Вторая или последующая степень (следующая за успешным завершением } \\
\text { программы бакалавриата или равнозначной ей программы) }\end{array}$ \\
\hline & & 758 & $\begin{array}{l}\text { Вторая или последующая степень (следующая за успешным завершением } \\
\text { программы магистратуры или равнозначной ей программы) }\end{array}$ \\
\hline \multirow[t]{4}{*}{76} & \multirow{4}{*}{$\begin{array}{l}\text { Магистратура или } \\
\text { её эквивалент, } \\
\text { ориентация не } \\
\text { определена' }\end{array}$} & 761 & Недостаточно для завершения уровня \\
\hline & & 766 & Долгосрочная первая степень (не менее 5 лет) \\
\hline & & 767 & $\begin{array}{l}\text { Вторая или последующая степень (следующая за успешным завершением } \\
\text { программы бакалавриата или равнозначной ей программы) }\end{array}$ \\
\hline & & 768 & $\begin{array}{l}\text { Вторая или последующая степень (следующая за успешным завершением } \\
\text { программы магистратуры равнозначной ей программы) }\end{array}$ \\
\hline
\end{tabular}

\section{Таблица 16. Коды классификации уровня полученного образования на уровне МСКО 7 (МСКО-У)}

\begin{tabular}{|c|c|c|c|}
\hline \multicolumn{2}{|r|}{ Категория (ориентация) } & \multirow{2}{*}{$\frac{\text { Подкатегория }}{640}$} & \multirow{2}{*}{ Описание } \\
\hline 64 & Бакалавриат или его эквивалент, академическое образование & & \\
\hline 65 & Бакалавриат или его эквивалент, профессиональное образование & 650 & Далее не определено' \\
\hline 66 & Бакалавриат или его эквивалент, ориентация не определена² & 660 & Далее не определено ${ }^{1}$ \\
\hline 74 & Магистратура или её эквивалент, академическое образование & 740 & Далее не определено ${ }^{3}$ \\
\hline 75 & Магистратура или её эквивалент, профессиональное образование & 750 & Далее не определено 3 \\
\hline 76 & Магистратура или её эквивалент, ориентация не определена² & 760 & Далее не определено 3 \\
\hline \multicolumn{4}{|c|}{$\begin{array}{l}\text { 1. Признанное успешное завершение программы либо этапа программы на уровне магистратуры или её эквивалента, недостаточной для успешного завершения уровня } \\
\text { МСК0 7. }\end{array}$} \\
\hline \multicolumn{4}{|c|}{$\begin{array}{l}\text { 2. Для применения на уровнях МСКО 6-8 в отсутствии согласованных на международном уровне определений программ и квалификаций для академической и } \\
\text { профессиональной ориентации на третичном уровне. }\end{array}$} \\
\hline \multicolumn{4}{|c|}{$\begin{array}{l}\text { 3. Включая признанное успешное завершение программы уровня магистратуры или её эквивалента, достаточное для завершения уровня МСКО 7, или программы либо } \\
\text { этапа программы на уровне докторантуры или её эквивалента, недостаточной для завершения уровня МСКО } 8 .\end{array}$} \\
\hline
\end{tabular}




\section{УРОВЕНЬ МСКО 8 ДОКТОРАНТУРА ИЛИ ЕЁ ЭКВИВАЛЕНТ}

\section{А. Основные характеристики}

259. Программы уровня МСКО 8, или «докторантура или её эквивалент», прежде всего, разработаны для того, чтобы привести к продвинутой квалификации в области научных исследований. Программы этого уровня МСКО посвящены углубленному и самостоятельному исследованию и, как правило, предлагаются только в учебных заведениях третичного образования, таких как университеты, ориентированных на исследования. Программы докторантуры существуют как в академической, так и в профессиональной областях.

260. Уровень МСКО 8 обычно завершается после представления и защиты диссертации или равнозначной письменной работы, заслуживающей публикации и представляющей значительный вклад в расширение знаний в соответствующей области изучения. Поэтому такие программы, как правило, основаны на исследовании, а не только на изучении материала курса. В некоторых системах образования программы уровня МСКО 8 содержат ограниченное количество курсов или они совсем отсутствуют, и соискатели степени доктора наук занимаются исследованиями в основном самостоятельно или в небольших группах с различной степенью руководства. В некоторых системах образования докторское исследование проводится сотрудниками университетов, работающими младшими научными сотрудниками или научными сотрудниками, дополнительно к обучению в докторантуре.

261. Поступление на программы МСКО 8 или прием на работу в качестве младшего научного сотрудника обычно требует успешного завершения программ МСКО 7. Квалификации уровня МСКО 8 дает доступ к профессиям, требующим высокого уровня владения академическими навыками, к ведению научно-исследовательской деятельности в правительстве, промышленности, а также доступ к исследовательским и преподавательским должностям в учебных заведениях, предлагающих образование на уровнях МСКО 6, 7 и 8.

262. Программы, относящиеся к уровню MCKO 8, могут называться по-разному, например, кандидат наук $(P h D)$, доктор наук/философии (DPhil), доктор литературы, (D.Lit), доктор (естественных) наук (D.Sc), доктор права (LL.D), докторская степень или аналогичные термины. Однако важно отметить, что программы с названиями, схожими с названием «доктор», следует включать в уровень МСКО 8, только если они соответствуют критериям, описанным в пункте 263. В целях сопоставимости данных на международном уровне для обозначения уровня МСКО 8 используется термин «докторантура или её эквивалент».

\section{B. Критерии классификации}

263. Для определения докторантуры или её эквивалента важны следующие критерии:

\section{Основные критерии}
а) Требования к письменной работе (диссертации) (см. пункт 264);
b) Требования к поступлению (см. пункт 261); и
с) Минимальная продолжительность уровня (см. пункт 265).

\section{Дополнительные критерии}

а) Степень доктора наук/квалификация, требуемая для занятия определенных должностей (см. пункт 266). 
264. Успешное завершение программы уровня МСКО 8 требует представления тезисов диссертации, диссертации или равнозначной письменной работы, заслуживающей публикации, которая является результатом самостоятельного исследования и представляет собой значительный вклад в расширение знаний в соответствующей области изучения.

265. Уровень МСКО 8 требует не менее трех лет в эквиваленте очного обучения при совокупной продолжительности очного обучения на программах третичного образования не менее семи лет.

266. Получение квалификации уровня МСКО 8 часто является условием для назначения на преподавательские должности в учебных заведениях, предлагающих обучение на программах уровня МСKO 6, 7 и 8, а также доступ к ведению научно-исследовательской деятельности в правительстве и промышленности.

\section{С. Программы, охватывающие несколько уровней MСКо}

267. Не применимо.

\section{D. Дополнительные параметры}

268. Образовательные программы уровня МСКО 8 различают по одному параметру:

- Ориентация программы (см. пункт 269).

\section{Ориентация программы}

269. Представлены две категории ориентации:

- Академическое образование; и

- Профессиональное образование.

\section{Е. Другие программы, включенные в уровень МСК0 8}

270. Вторые продвинутые исследовательские квалификации, или более высокие уровни степени доктора наук могут также относиться к уровню МСКО 8. Эти квалификации требуют представления второй важной исследовательской работы (в продолжение кандидатской диссертации), которая обычно выполняется на значительно более поздней стадии академической карьеры и часто без официального руководства. Примерами являются квалификации habilitation или доктор наук, хотя в большинстве систем образования существует лишь одна продвинутая исследовательская квалификация, предоставляющая степень доктора наук или равнозначные квалификации. Эти квалификации обычно не связаны с образовательной программой (т. е. кандидаты обычно не являются учащимися на программе, которая ведет к получению таких квалификаций). Вторая исследовательская степень не кодируется отдельно в рамках МСКО. Почетная докторская степень, присваиваемая университетами на основе других положений, а не исследовательской работы, не включается в уровень МСКО 8.

\section{F. Классификация образовательных программ на уровне МСК0 8}

271. Образовательные программы уровня МСКО 8 являются или полными программами докторантуры или этапами (или программами) на уровне докторантуры, недостаточными для завершения уровня МСКО 8. Для формирования отчетности применение дополнительного параметра позволяет использовать категории для определения ориентации программ. Коды, которые следует применять для уровня МСКО 8, представлены в таблице 17. 
Таблица 17. Коды классификации образовательных программ уровня МСКО 8 (МСКО-П)

\begin{tabular}{|c|c|c|c|}
\hline \multicolumn{2}{|r|}{$\begin{array}{c}\text { Категория } \\
\text { (Ориентация) }\end{array}$} & $\begin{array}{c}\text { Подкатегория (Уровень } \\
\text { завершения) }\end{array}$ & Описание \\
\hline \multirow[t]{2}{*}{84} & \multirow{2}{*}{$\begin{array}{l}\text { Докторантура или её эквивалент, } \\
\text { академическое образование }\end{array}$} & 841 & Недостаточно для завершения уровня \\
\hline & & 844 & Достаточно для завершения уровня \\
\hline \multirow[t]{2}{*}{85} & \multirow{2}{*}{$\begin{array}{l}\text { Докторантура или её эквивалент, } \\
\text { профессиональное образование }\end{array}$} & 851 & Недостаточно для завершения уровня \\
\hline & & 854 & Достаточно для завершения уровня \\
\hline \multirow[t]{2}{*}{86} & \multirow{2}{*}{$\begin{array}{l}\text { Докторантура или её эквивалент, } \\
\text { ориентация не определена' }\end{array}$} & 861 & Недостаточно для завершения уровня \\
\hline & & 864 & Достаточно для завершения уровня \\
\hline
\end{tabular}

\section{G. Классификация уровня полученного образования на уровне MCKO 8}

272. При оценке уровня полученного образования признанные промежуточные квалификации успешного завершения этапов (или программ) в рамках первой степени на уровне степени на уровне докторантуры или её эквивалента, но не считающиеся достаточными для завершения уровня MCKO 8, относятся к уровню МСКО 7. Участие в программах без признанного успешного завершения любой программы первой степени на уровне МСКО 8 не учитывается для определения уровней образования.

273. Коды классификации уровня полученного образования, относящиеся к уровню МСКО 8, представлены в таблице 18.

\section{Таблица 18. Коды классификации уровня полученного образования на уровне МСКО 8 (МСКО-У)}

\begin{tabular}{|c|c|c|c|}
\hline \multicolumn{2}{|r|}{ Категория (Ориентация) } & Подкатегория & Описание \\
\hline 74 & Магистратура или её эквивалент, академическое образование & 740 & Далее не определено' \\
\hline 75 & Магистратура или её эквивалент, профессиональное образование & 750 & Далее не определено' \\
\hline 76 & Магистратура или её эквивалент, ориентация не определена² & 760 & Далее не определено' \\
\hline 84 & Докторантура или её эквивалент, академическое образование & 840 & Далее не определено \\
\hline 85 & Докторантура или её эквивалент, профессиональное образование & 850 & Далее не определено \\
\hline 86 & Докторантура или её эквивалент, ориентация не определена² & 860 & Далее не определено \\
\hline \multicolumn{4}{|c|}{$\begin{array}{l}\text { 1. Признанное успешное завершение программы либо этапа программы уровня докторантуры или её эквивалента, недостаточное для успешного завершения уровн } \\
\text { МСК0 8. }\end{array}$} \\
\hline
\end{tabular}




\section{ГЛАВА 10 СООТВЕТСТВИЕ УРОВНЕЙ МСКО 2011 И МСКО 1997}

274. В этой главе описывается соответствие уровней в классификации МСКО 2011 и её предыдущей версии, МСКО 1997.

275. Уровень 0 МСКО 2011 охватывает образование детей младшего возраста всех возрастов, включая совсем маленьких детей. Программы подразделяются на две категории в зависимости от уровня сложности содержания образования: программы развития детей младшего возраста (код 010) и дошкольное образование (код 020). Программы развития детей младшего возраста (код 010) в целом предназначены для детей младше 3 лет. Классификация этих программ введена в качестве новой категории в МСКО 2011 и такие программы не были классифицированы в рамках МСКО 1997. Дошкольное образование (код 020) точно соответствует уровню 0 МСКО 1997.

276. Уровень 1, начальное образование, в МСКО 2011 соответствует уровню 1 в МСКО 1997.

277. Уровни 2 и 3 МСКО 2011, первый и второй этапы среднего образования в основном соответствуют уровням 2 и 3 МСКО 1997. Однако за счет уточнения критериев и дополнительных критериев МСКО 2011 можно применять иначе, чем МСКО 1997 (т.е. некоторые программы отнесены к иному уровню, чем в предыдущей версии). В некоторых странах такие различия могут оказывать воздействие на данные временного ряда.

278. По сравнению с МСКО 1997, в МСКО 2011 упрощены дополнительные параметры на уровнях MCKO 2 и 3:

- Ориентация программ МСКО 2011 различается только по профессиональным и общим программам. В МСКО 1997 отдельно выделяется подготовительное профессиональное образование. Такие программы не предоставляют квалификации, имеющие значение на рынке труда, и в МСКО 2011 относятся к общему образованию;

- В МСКО 2011 выделена лишь одна группа программ, дающих доступ к более высоким уровням МСКО. Для сравнения, МСКО 1997 проводит различия доступа к более высоким уровням МСКО по категориям A и B, в зависимости от типа последующего образования. Категория МСКО 2011 «завершение уровня с доступом к более высоким уровням МСКО» соответствует объединенным категориям А и В в МСКО 1997;

- В МСКО 2011 программы, которые не дают доступа к более высоким уровням MCKO, подразделяются на подкатегории «уровень не завершен», «неполное завершение уровня» и «завершение уровня». Эти три подкатегории МСКО 2011, как правило, в МСКО 1997 соответствуют категории C, а на уровне МСКО 3 - категориями «С короткая» и «С длинная».

279. Уровень 4 МСКО 2011, послесреднее нетретичное образование, в основном соответствует уровню 4 МСКО 1997. Однако программы, ведущие к квалификациям, равнозначным второму этапу общего среднего образования, в МСКО 2011 относятся к уровню 3, в то время как в МСКО 1997 они часто относятся к уровню 4. В дополнение к этому, за счет уточнения критериев и дополнительных критериев МСКО 2011 можно применять иначе, чем МСКО 1997. В некоторых странах такие различия могут оказывать воздействие на данные временного ряда.

280. В МСКО 2011 упрощены параметры ориентации на уровне МСКО 4 в отношении уровней 2 и 3 (см. пункты 194, 153, 175). В МСКО 2011 подкатегории «доступ к более высоким уровням МСКО» и «нет доступа к более высоким уровням MCKO» аналогичны соответствующим позициям А и В в МСКО 1997. 
281. По сравнению с двумя уровнями МСКО 1997, в МСКО 2011 выделены четыре уровня третичного образования. Уровни 5, 6 и 7 МСКО 2011 вместе соответствуют уровню 5 МСКО 1997. Уровень 8 МСКО 2011 соответствует уровню 6 МСКО 1997.

282. По сравнению с МСКО 1997 в МСКО 2011 упрощены дополнительные параметры на уровнях третичного образования:

- На уровне 5 МСКО 2011 программы профессионального образования отличаются от общих программ по второй цифре. В МСКО 1997 подобного разграничения не существовало. Когда будут разработаны согласованные на международном уровне определения академической и профессиональной ориентации, будет возможно их разграничения в рамках МСКО на уровнях 6-8.

- На уровнях 6 и 7 МСКО 2011 третья цифра классификации различает программы в соответствии с их продолжительностью и положением в национальной структуре степеней и квалификаций для подсчета таких статистических показателей, как уровень поступления и выпуска. В МСКО 1997 ориентация программы или «тип программы» использовался для подразделения МСКО 5А на программы первой степени и программы второй и последующей степеней (соответственно, уровень 5А МСКО 1997 подразделяется в МСКО 2011 на уровни МСКО 6 и 7). Третья цифра классификации программы позволяет провести различие между первой степенью и второй и последующей степенью на обоих уровнях.

283. В таблице 19 представлено соответствие между уровнями МСКО версий 2011 и 1997.

\section{Таблица 19. Соответствие между уровнями МСКО 2011 и МСКО 1997}

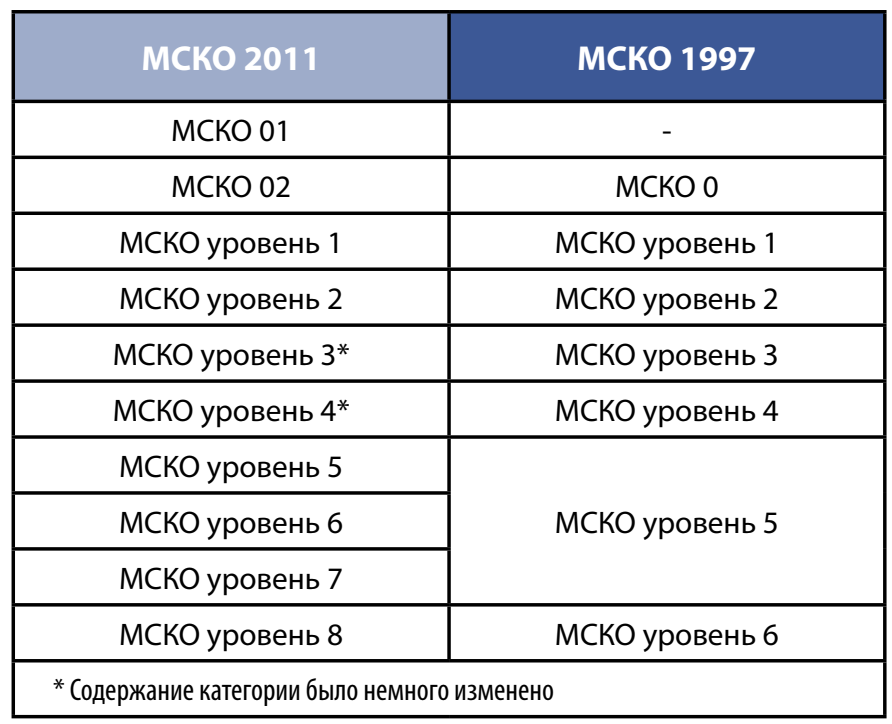

284. В таблицах 20 и 21 представлено подробное соответствие между МСКО 2011 и МСКО 1997, включая дополнительные параметры, категории и подкатегории 


\section{Таблица 20. Подробное соответствие между МСКО 2011 и МСКО 1997. Уровни 0-4}

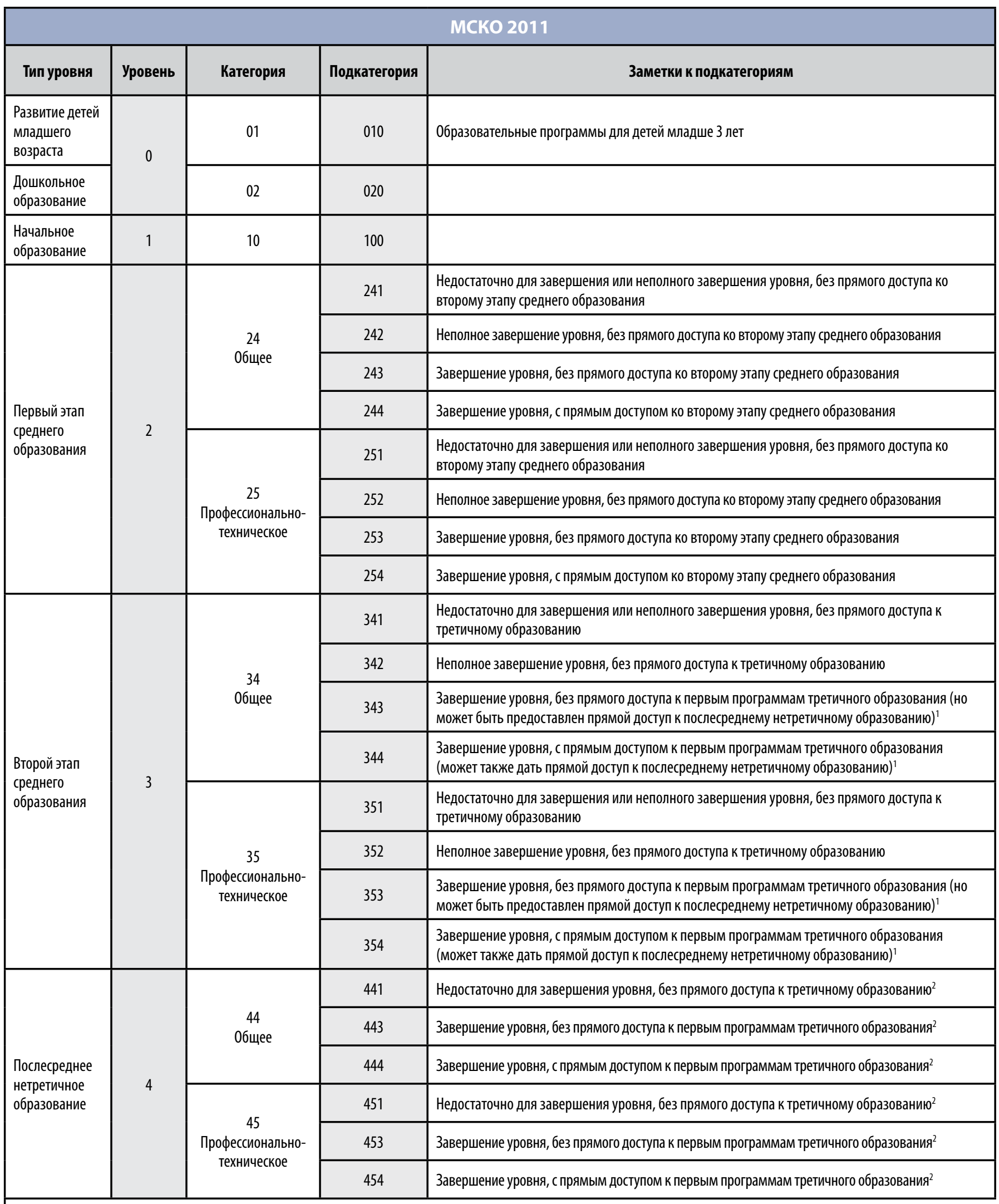

1. Может включать программы, ранее отнесенные к уровню МСКО 4, если они эквивалентны программам уровня МСКО 3.

2. За исключение программ, ранее отнесенных к уровню МСКО 4, если они эквивалентны программам уровня МСК0 3. 


\begin{tabular}{|c|c|c|c|}
\hline \multicolumn{4}{|c|}{ MCKO 1997} \\
\hline Тип уровня & Уровень & $\begin{array}{c}\text { Вид последующего } \\
\text { образования или занятия }\end{array}$ & Ориентация \\
\hline \multicolumn{4}{|l|}{ B MCКО 1997 отсутствует } \\
\hline Дошкольное образование & 0 & не применимо & не применимо \\
\hline Начальное образование или первый этап базового образования & 1 & не применимо & не применимо \\
\hline \multirow{8}{*}{ Первый этап среднего образования или второй этап базового образования } & \multirow{8}{*}{2} & C & \multirow{4}{*}{$\begin{array}{c}\text { Общее/ } \\
\text { Допрофессиональное или } \\
\text { дотехническое образование }\end{array}$} \\
\hline & & C & \\
\hline & & C & \\
\hline & & $A / B$ & \\
\hline & & C & \multirow{4}{*}{$\begin{array}{c}\text { Профессионально-техническое } \\
\text { образование }\end{array}$} \\
\hline & & C & \\
\hline & & C & \\
\hline & & $A / B$ & \\
\hline \multirow{8}{*}{ Второй этап среднего образования } & \multirow{8}{*}{3} & C & \multirow{4}{*}{$\begin{array}{c}\text { 0бщее/ } \\
\text { Допрофессиональное или } \\
\text { дотехническое образование }\end{array}$} \\
\hline & & C & \\
\hline & & C & \\
\hline & & $A / B$ & \\
\hline & & C & \multirow{4}{*}{$\begin{array}{c}\text { Профессионально-техническое } \\
\text { образование }\end{array}$} \\
\hline & & C & \\
\hline & & C & \\
\hline & & $A / B$ & \\
\hline \multirow{6}{*}{ Послесреднее нетретичное образование } & \multirow{6}{*}{4} & $B$ & \multirow{3}{*}{$\begin{array}{c}\text { 0бщее/ } \\
\text { Допрофессиональное или } \\
\text { дотехническое образование }\end{array}$} \\
\hline & & B & \\
\hline & & $A$ & \\
\hline & & $B$ & \multirow{3}{*}{$\begin{array}{c}\text { Профессионально-техническое } \\
\text { образование }\end{array}$} \\
\hline & & $B$ & \\
\hline & & B & \\
\hline
\end{tabular}




\section{Таблица 21. Подробное соответствие между МСКО 2011 и МСКО 1997, уровни третичного образования}

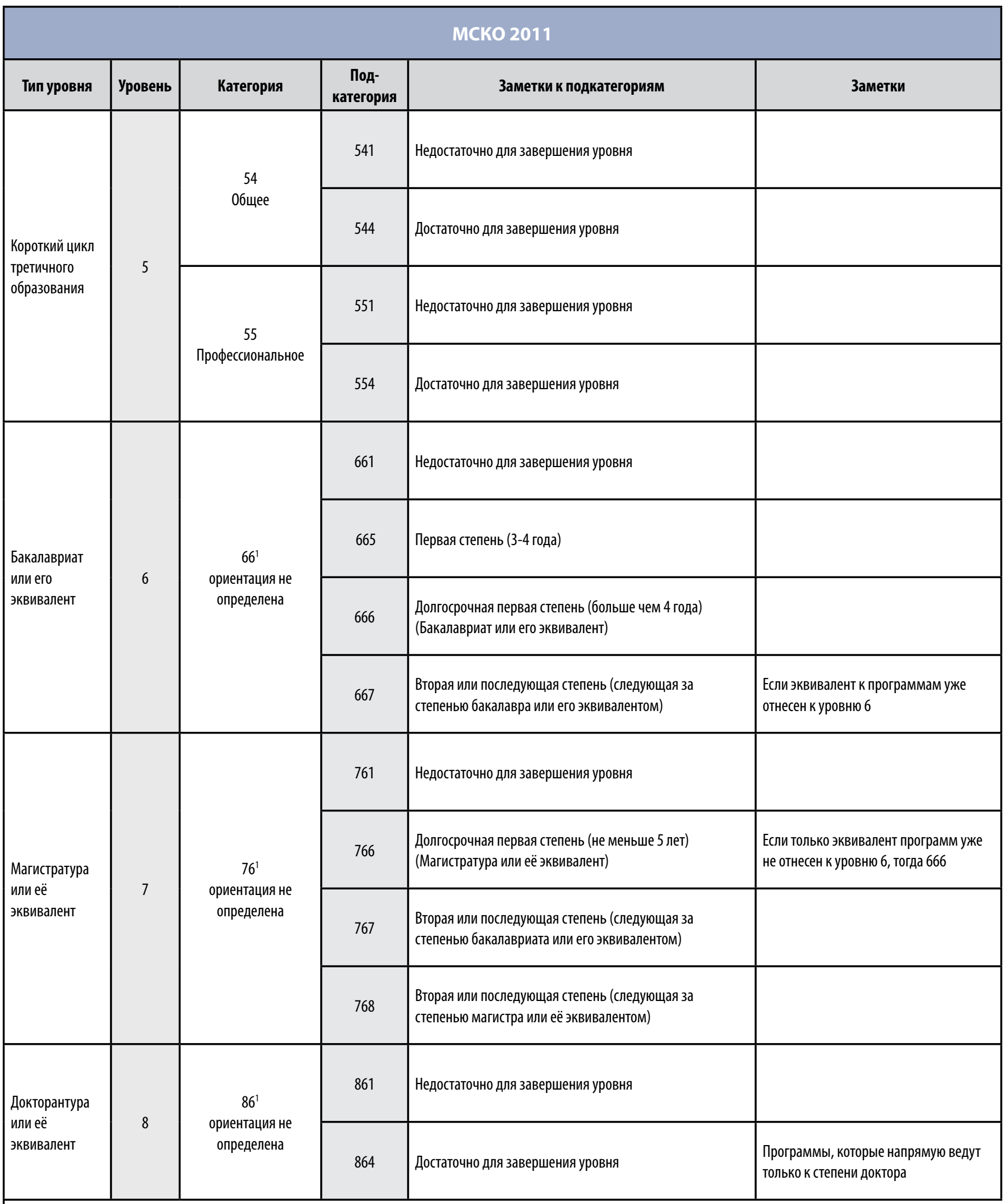

1. Категория «ориентация не определена» относится к уровням МСКО 6, 7 и 8 для академической и профессиональной ориентации. 


\begin{tabular}{|c|c|c|c|c|}
\hline \multicolumn{5}{|c|}{ MCKO 1997} \\
\hline Тип уровня & Уровень & Тип & Положение & $\begin{array}{l}\text { Совокупная продолжительность } \\
\text { третичного образования }\end{array}$ \\
\hline \multirow{12}{*}{ Первый этап третичного образования } & 5 & B & не применимо & $<2$ лет \\
\hline & 5 & B & не применимо & $\geq 2$ года \\
\hline & 5 & B & не применимо & $<2$ лет \\
\hline & 5 & B & не применимо & $\geq 2$ года \\
\hline & 5 & A & промежуточная & $<3$ лет \\
\hline & 5 & $A$ & $1^{\text {я }}$ & 3-4 года \\
\hline & 5 & A & $1^{\text {я }}$ & $>4$ лет \\
\hline & 5 & A & $\begin{array}{c}2^{9} / \\
\text { последующая }\end{array}$ & $\geq 4$ года \\
\hline & 5 & A & промежуточная & $<4$ лет \\
\hline & 5 & A & $1^{\text {я }}$ & $\geq 5$ лет \\
\hline & 5 & A & $\begin{array}{c}2^{a /} \\
\text { последующая }\end{array}$ & $\geq 4-5$ лет \\
\hline & 5 & A & $\begin{array}{c}2^{\natural /} \\
\text { последующая }\end{array}$ & $\geq 6$ лет \\
\hline \multirow{2}{*}{ Второй этап третичного образования } & 6 & не применимо & не применимо & не применимо \\
\hline & 6 & не применимо & не применимо & не применимо \\
\hline
\end{tabular}




\section{ПРИЛОЖЕНИЕ| ВОЗМОЖНЫЕ ПУТИ ПОЛУЧЕНИЯ ОБРАЗОВАНИЯ В СООТВЕТСТВИИ С МСКО 2011}

Схема 2. Возможные пути получения образования в соответствии с МСКО 2011

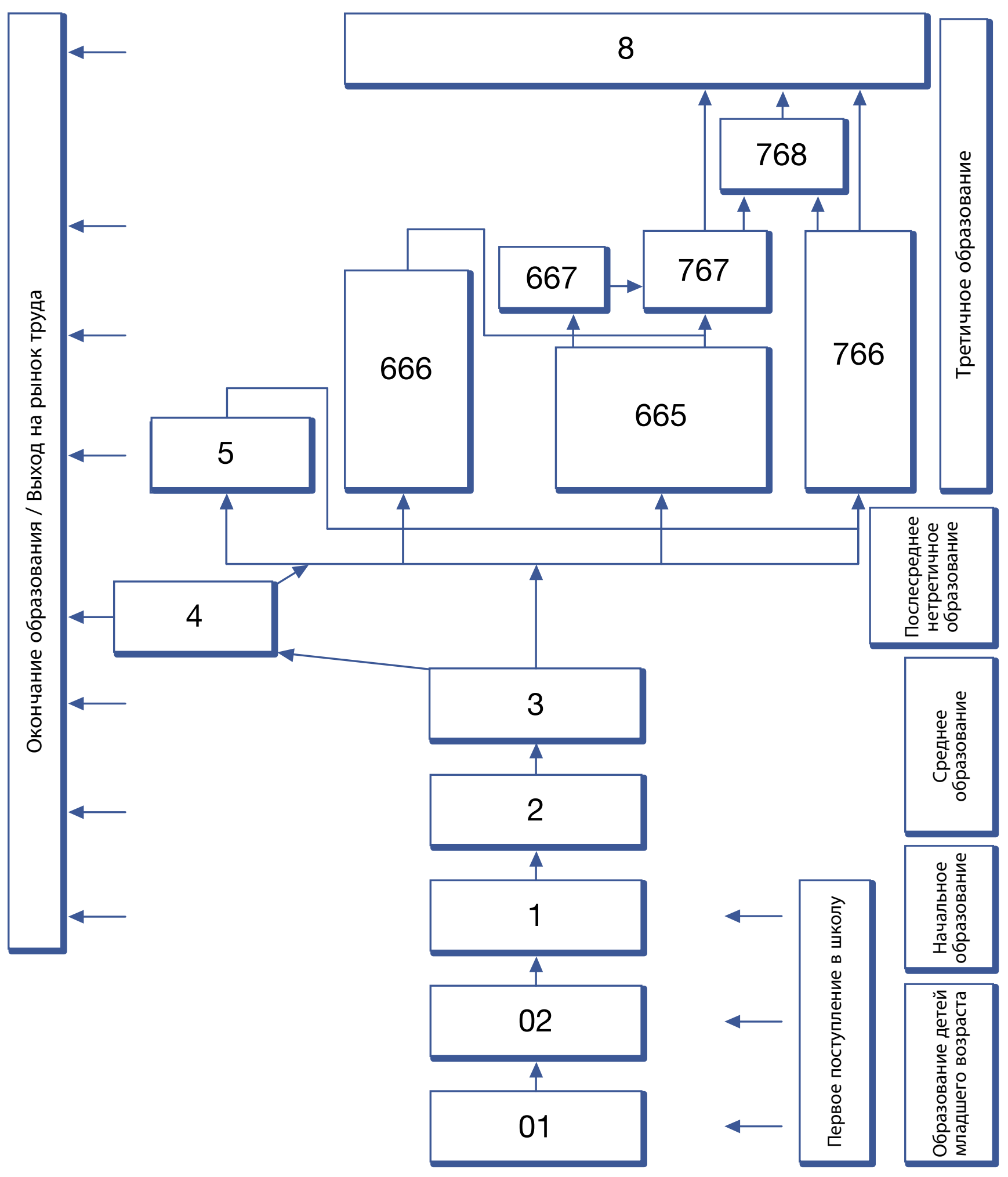




\section{ПРИЛОЖЕНИЕ ІІ СИСТЕМА КОДИРОВАНИЯ ОБРАЗОВАТЕЛЬНЫХ ПРОГРАММ}

\section{0 Образование детей младшего возраста}

01 Программы развития детей младшего возраста

010 Программы развития детей младшего возраста

02 Дошкольное образование

020 Дошкольное образование

\section{1 Начальное образование}

10 Начальное образование

100 Начальное образование

\section{2 Первый этап среднего образования}

24 Общее

241 Недостаточно для завершения или неполного завершения уровня и без прямого доступа ко второму этапу среднего образования

242 Достаточно для неполного завершения уровня, без прямого доступа ко второму этапу среднего образования

243 Достаточно для завершения уровня, без прямого доступа ко второму этапу среднего образования

244 Достаточно для завершения уровня, с прямым доступом ко второму этапу среднего образования

25 Профессионально-техническое

251 Недостаточно для завершения или неполного завершения уровня, без прямого доступа ко второму этапу среднего образования

252 Достаточно для неполного завершения уровня, без прямого доступа ко второму этапу среднего образования

253 Достаточно для завершения уровня, без прямого доступа ко второму этапу среднего образования

254 Достаточно для завершения уровня, с прямым доступом ко второму этапу среднего образования

\section{3 Второй этап среднего образования}

34 Общее

341 Недостаточно для завершения или неполного завершения уровня, без прямого доступа к третичному образованию

342 Достаточно для неполного завершения уровня, без прямого доступа к третичному образованию 343 Достаточно для завершения уровня, без прямого доступа к третичному образованию 344 Достаточно для завершения уровня, с прямым доступом к третичному образованию 35 Профессионально-техническое

351 Недостаточно для завершения или неполного завершения уровня, без прямого доступа к третичному образованию

352 Достаточно для неполного завершения уровня, без прямого доступа к третичному образованию 353 Достаточно для завершения уровня, без прямого доступа к третичному образованию 354 Достаточно для завершения уровня, с прямым доступом к третичному образованию

\section{4 Послесреднее нетретичное образование}

\section{4 Общее}

441 Недостаточно для завершения уровня, без прямого доступа к третичному образованию 443 Достаточно для завершения уровня, без прямого доступа к третичному образованию 444 Достаточно для завершения уровня, с прямым доступом к третичному образованию 
45 Профессионально-техническое

451 Недостаточно для завершения уровня, без прямого доступа к третичному образованию 453 Достаточно для завершения уровня, без прямого доступа к третичному образованию 454 Достаточно для завершения уровня, с прямым доступом к третичному образованию

\section{5 Короткий цикл третичного образования}

\section{4 Общее $^{1}$}

541 Недостаточно для завершения уровня

544 Достаточно для завершения уровня

55 Профессиональное ${ }^{1}$

551 Недостаточно для завершения уровня

554 Достаточно для завершения уровня

\section{6 Бакалавриат или его эквивалент}

64 Академическое

641 Недостаточно для завершения уровня

645 Первая степень (3-4 года)

646 Долгосрочные программы первой степени (более 4 лет)

647 Вторая и последующая степень (следующая за программой бакалавриата или равнозначной ей)

65 Профессиональное

651 Недостаточно для завершения уровня

655 Первая степень (3-4 года)

656 Долгосрочные программы первой степени (более 4 лет)

657 Вторая и последующая степень (следующая за программой бакалавриата или равнозначной ей)

66 Ориентация не определена'

661 Недостаточно для завершения уровня

665 Первая степень (3-4 года)

666 Долгосрочные программы первой степени (более 4 лет)

667 Вторая и последующая степень (следующая за программой бакалавриата или равнозначной ей)

\section{7 Магистратура или её эквивалент}

74 Академическое

741 Недостаточно для завершения уровня

746 Долгосрочная первая степень (не менее 5 лет)

747 Вторая и последующая степень (следующая за программой бакалавриата или равнозначной ей)

748 Вторая и последующая степень (следующая за программой магистратуры или равнозначной ей)

75 Профессиональное

751 Недостаточно для завершения уровня

756 Долгосрочная первая степень (не менее 5 лет)

757 Вторая и последующая степень (следующая за программой бакалавриата или равнозначной ей) 758 Вторая и последующая степень (следующая за программой магистратуры или равнозначной ей)

76 Ориентация не определена'

761 Недостаточно для завершения уровня

766 Долгосрочная первая степень (не менее 5 лет)

767 Вторая и последующая степень (следующая за программой бакалавриата или равнозначной ей)

768 Вторая и последующая степень (следующая за программой магистратуры или равнозначной ей) 


\section{8 Докторантура или её эквивалент}

84 Академическое

841 Недостаточно для завершения уровня

844 Достаточно для завершения уровня

85 Профессиональное

851 Недостаточно для завершения уровня

854 Достаточно для завершения уровня

86 Ориентация не определена'

861 Недостаточно для завершения уровня

864 Достаточно для завершения уровня

\section{9 Не классифицировано}

99 Не классифицировано

999 Не классифицировано

1. Для применения в отсутствии согласованных на международном уровне определений программ и квалификаций для академической и профессиональной ориентации на третичном уровне. 


\section{ПРИЛОЖЕНИЕ ІІІ СИСТЕМА КОДИРОВАНИЯ УРОВНЯ ПОЛУЧЕННОГО ОБРАЗОВАНИЯ}

\section{о Ниже начального образования}

01 Никогда не посещавшие образовательную программу 010 никогда не посещавшие образовательную программу

02 Некоторые программы образования детей младшего возраста 020 некоторые программы образования детей младшего возраста

03 Некоторые программы начального образования (без завершения уровня) 030 некоторые программы начального образования (без завершения уровня)

\section{1 Начальное образование}

10 Начальное

100 Включая признанное успешное завершение программы первого этапа среднего образования, недостаточное для завершения уровня или неполного завершения уровня

\section{2 Первый этап среднего образования}

24 Общее

242 Неполное завершение уровня, без прямого доступа ко второй ступени среднего образования

243 Завершение уровня, без прямого доступа ко второй ступени среднего образования

244 Завершение уровня с прямым доступом ко второй ступени среднего образования ${ }^{1}$

25 Профессионально-техническое 1

252 Неполное завершение уровня, без прямого доступа ко второй ступени среднего образования

253 Завершение уровня, без прямого доступа ко второй ступени среднего образования

254 Завершение уровня с прямым доступом ко второй ступени среднего образования ${ }^{1}$

\section{3 Второй этап среднего образования ${ }^{1}$}

34 Общее ${ }^{1}$

342 Неполное завершение уровня, без прямого доступа к третичному образованию

343 Завершение уровня, без прямого доступа к третичному образованию

344 Завершение уровня, с прямым доступом к третичному образованию'

35 Профессионально-техническое ${ }^{1}$

352 Неполное завершение уровня, без прямого доступа к третичному образованию

353 Завершение уровня, без прямого доступа к третичному образованию

354 Завершение уровня, с прямым доступом к третичному образованию'

4 Послесреднее нетретичное образование ${ }^{1}$

44 Общее

443 Завершение уровня, без прямого доступа к третичному образованию

444 Завершение уровня, с прямым доступом к третичному образованию'

45 Профессионально-техническое ${ }^{1}$

453 Завершение уровня, без прямого доступа к третичному образованию

454 Завершение уровня, с прямым доступом к третичному образованию'

\section{5 Короткий цикл третичного образования'}

54 Общее ${ }^{1,2}$

540 Далее не определено'

55 Профессиональное ${ }^{1,2}$

550 Далее не определено ${ }^{1}$

56 Ориентация не определена ${ }^{1,2}$

560 Далее не определено ${ }^{1}$ 


\section{6 Бакалавриат или его эквивалент ${ }^{\mathbf{1}}$}

64 Академическое ${ }^{1}$

640 Далее не определено ${ }^{1}$

65 Профессиональное ${ }^{1}$ 650 Далее не определено

66 Ориентация не определена ${ }^{1,2}$ 660 Далее не определено'

\section{7 Магистратура или её эквивалент ${ }^{1}$}

74 Академическое ${ }^{1}$

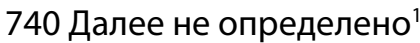

75 Профессиональное ${ }^{1}$ 750 Далее не определено ${ }^{1}$

76 Ориентация не определена ${ }^{1,2}$ 760 Далее не определено ${ }^{1}$

\section{8 Докторантура или её эквивалент ${ }^{1}$}

84 Академическое $^{1}$

840 Далее не определено

85 Профессиональное $^{1}$

850 Далее не определено

86 Ориентация не определена ${ }^{1,2}$

860 Далее не определено

\section{9 Не классифицировано}

99 Не классифицировано

999 Не классифицировано

1. Включая успешное завершение программы на данном уровне, достаточное для завершения уровня, или успешное завершение программы, либо этапа программы на более высоком уровне МСКО, недостаточное для завершения или неполного завершения более высокого уровня.

2. Для применения в отсутствии согласованных на международном уровне определений программ и квалификаций для академической и профессиональной ориентации на третичном уровне. 


\section{ПРИЛОЖЕНИЕ IV РАСШИРЕННЫЕ ГРУППЫ И ОБЛАСТИ ОБРАЗОВАНИЯ}

285. Определения текущих областей образования остались без изменения относительно версии МСКО 1997. ИСЮ планирует разработать трехзначную подробную классификацию областей образования и обучения, основываясь на проекте системы кодирования, разработанной для ЮНЕСКО в 1999 году. Это кодирование применялось Евростатом и ОЭСР более десяти лет, но требует дальнейшего обновления. Когда новая классификация областей образования и обучения будет официально принята Генеральной конференцией ЮНЕСКО, она будет считаться отдельной и независимой от МСКО классификацией и данный раздел будет удален.

286. В МСКО - 25 областей, организованных в 9 расширенных групп. Рекомендуется классифицировать меж- или полидисциплинарные программы в соответствии с правилом большинства, т. е. в области образования, на которую приходится большая часть времени обучения.

Области образования МСКО:

\section{0 Общие программы}

\section{1 Базовые программы}

Базовые общие программы: доначальные, дошкольные, элементарные начальные, средние и т. д.

\section{8 Грамотность и навыки счета}

Простая и функциональная грамотность, навыки счета.

\section{9 Развитие личности}

Развитие личных навыков, т.е. бихевиористских способностей, умственных навыков, самоорганизации, программ жизненной ориентации.

\section{1 Образование}

\section{4 Подготовка учителей и педагогическая наука}

Подготовка учителей для дошкольных учреждений, детских садов, начальных школ по профессиональным предметам, практическим предметам, непрофессиональным предметам, образованию взрослых, инструкторов по подготовке учителей и для работы с детьми-инвалидами. Программы общей и специализированной подготовки учителей.

Педагогическая наука: разработка учебных программ по непрофессиональным и профессиональным предметам. Оценка образования, проведение экзаменов и тестов, исследования в области образования, другие педагогические науки.

\section{2 Гуманитарные науки и искусство}

\section{1 Искусство}

Изобразительное искусство: рисунок, живопись, скульптура;

Исполнительское искусство: музыкальное, драматическое, танцевальное, цирковое;

Графическое и аудиовизуальное искусство: фотография, кинематография, звукозапись, производство радио- и телевизионных передач, печать и издательское дело;

Дизайн; Ремесла.

\section{2 Гуманитарные науки}

Религия и теология; иностранные языки и культуры: живые или "мертвые" языки и литература на этих языках, изучение отдельных областей;

Родные языки: общеупотребительный или местный язык и литература на нем; Другие гуманитарные науки: устный и письменный перевод, лингвистика, сравнительное литературоведение, история, археология, философия, этика. 


\section{3 Социальные науки, бизнес и право}

\section{1 Социальные и бихевиористские науки}

Экономика, история экономики, политология, социология, демография, антропология (за исключением физической антропологии), этнология, футурология, психология, география (за исключением физической географии), изучение проблем мира и конфликтов, права человека.

\section{2 Журналистика и информация}

Журналистика; технические и научные аспекты библиотечной работы; технические аспекты работы музеев и аналогичных хранилищ;

Документоведение;

Архивные науки.

\section{4 Бизнес и управление}

Розничная продажа, маркетинг, сбыт, связи с общественностью, недвижимость;

финансы, банковское и страховое дело, анализ капиталовложений;

бухгалтерское дело, аудит, бухгалтерский учет;

менеджмент, управление государственными органами, управление негосударственными органами, управление кадрами;

делопроизводство и конторская работа.

\section{8 Право}

Местные судьи, нотариусы, право (общее, международное, трудовое, морское и другое), юриспруденция, история права.

\section{4 Наука}

\section{2 Науки о жизни}

Биология, ботаника, бактериология, токсикология, микробиология, зоология, энтомология, орнитология, генетика, биохимия, биофизика, другие смежные науки, за исключением лечебно-медицинских и ветеринарных наук.

\section{4 Физические науки}

Астрономия и космология, физика, другие смежные предметы, химия, другие смежные предметы, геология, геофизика, минералогия, физическая антропология, физическая география и другие науки о Земле, метеорология и другие науки об атмосфере, включая исследование климата, океанография, вулканология, палеоэкология.

\section{6 Математика и статистика}

Математика, вычислительные науки, цифровой анализ, актуарная наука, статистика и другие смежные области.

\section{8 Компьютерное дело}

Компьютерные науки: проектирование систем, компьютерное программирование, обработка данных, сети, действующие системы - только разработка программного обеспечения (разработка компьютерного оборудования должна классифицироваться в рамках инженерных областей).

\section{5 Инженерные, обрабатывающие и строительные отрасли}

\section{2 Инженерия и инженерное дело}

Инженерное черчение, механика, металлообработка, электротехника, телекоммуникация, энергетика и химическая инженерия, обслуживание автомобилей, инженерное проектирование.

\section{4 Производственные и обрабатывающие отрасли}

Производство продуктов питания и напитков, ткани, одежды, обуви, кожаных изделий, материалов (древесина, бумага, пластмасса, стекло и т. д. ), горное дело и добыча полезных ископаемых. 


\section{8 Архитектура и строительство}

Архитектура и городское планирование: структурная архитектура, ландшафтная архитектура, общинное планирование, картография;

строительные работы, строительство;

гражданское строительство.

\section{6 Сельское хозяйство}

\section{2 Сельское, лесное и рыболовное хозяйство}

Сельское хозяйство, производство сельскохозяйственных культур и выращивание скота, агрономия, животноводство, плодоводство и садоводство, лесное хозяйство и методы производства лесной продукции, природные парки, дикая природа, рыболовство, рыболовная наука и технология.

\section{4 Ветеринария}

Ветеринарная медицина, ветеринарное обслуживание.

\section{7 Здравоохранение и социальное обеспечение}

\section{2 Здравоохранение}

Медицина: анатомия, эпидемиология, цитология, физиология, иммунология и иммуногематология, патология, анестезиология, педиатрия, акушерство и гинекология, медицина внутренних органов, хирургия, неврология, психиатрия, радиология, офтальмология; Медицинские службы: государственные службы здравоохранения, гигиена, фармацевтика, фармакология, терапевтика, реабилитация, протезирование, оптометрия, питание;

Уход за больными: общий уход за больными, акушерство;

Стоматология: ассистирование в стоматологии, стоматологическая гигиена, зубное протезирование, одонтология.

\section{6 Социальное обеспечение}

Социальные услуги: уход за инвалидами, уход за детьми, молодежные службы, геронтологические службы;

Социальная работа: консультирование, социальное обеспечение нигде ранее не классифицированное.

\section{8 Службы}

\section{1 Сфера обслуживания}

Гостиничное обслуживание и сфера питания, путешествия и туризм, спорт и досуг, парикмахерские, косметические салоны и другое обслуживание населения: чистка одежды, прачечные, химчистки, косметические службы, науки о быте.

\section{4 Транспорт}

Морское дело, командный состав судов, морская навигация, летные экипажи, авиадиспетчеры, железнодорожные перевозки, автодорожные перевозки, почтовые службы.

\section{5 Охрана окружающей среды}

Сохранение окружающей среды, контроль и охрана, контроль загрязнения воздушной и водной среды, техника безопасности на рабочих местах.

\section{6 Службы безопасности}

Охрана собственности и граждан: работа полиции и сопутствующие меры по обеспечению правопорядка криминалистика, пожарная охрана и борьба с пожарами, гражданская безопасность;

Военное дело.

\section{Неизвестная или неуточненная категория}

(Эта категория как таковая не входит в данную классификацию, однако при сборе данных позиция "99" необходима для "неизвестных или неуточненных областей образования".) 
287. МСКО 2011 дано определение неформального образования (пункт 39) и представлены типы неформального образования (пункт 40). Подчеркнуто, что неформальное образование, которое обычно не дает доступ к более высокому уровню образования, если только программа неt утверждена в системе формального образования (пункт 41), и рекомендовано использовать критерий эквивалентности содержания и/или полученной квалификации для классификации программ неформального образования (пункт 42).

288. В этом приложении представлены дополнительные характеристики, касающиеся неформального образования. Концепт программ неформального образования нуждается в дальнейшей разработке для точного сопоставления статистических данных на международном уровне. В международной практике существуют примеры опыта сбора данных, к которому можно обратиться для консультации.

289. В пункте 40 МСКО 2011 отмечается, что в зависимости от национального контекста, неформальное образование и подготовка охватывает программы:

i) по ликвидации неграмотности взрослых и молодежи и образованию детей, не посещающих школу (альтернативные первоначальному образованию программы);

ii) направленные на развитие жизненных и трудовых навыков, а также социальное и культурное развитие.

Последнее может включать:

- подготовку на рабочем месте для совершенствования или адаптации существующей квалификации или навыков, обучение безработных или представителей экономически неактивного населения; и

- учебную деятельность, направленную на саморазвитие (во время досуга).

290. Для сопоставимости данных на международном уровне сложно предоставить общие указания для применения статистических инструментов в силу неоднородности программ неформального образования. Для классификации программ неформального образования МСКО 2011 рекомендует применять критерий эквивалентности содержания. Эквивалентность содержания устанавливает взаимосвязь между программами неформального образования и программами формального образования аналогичными по содержанию в рамках МСКО. Это в принципе позволяет классифицировать программы неформального образования по уровням. Например, если программа образования для взрослых соответствует критериям содержания уровня МСКО 1, она могла бы быть отнесена к уровню МСКО 1.

291. Классификации образовательных программ, присвоенные после успешного завершения программы неформального образования, часто помогают при классификации образовательной программы. Например, неформальная программа профессиональной подготовки, как и программа формального образования, может быть классифицирована на основе эквивалентности уровня и типа квалификации (если таковая имеется), полученной после ее успешного завершения. Национальные и региональные квалификационные рамки, там, где они существуют, могут способствовать установлению эквивалентности содержания программ и классификаций в рамках одной системы образования. МСКО 2011 предоставляет четкое определение программ формального и неформального образования соответственно. 
292. Неформальное образование может предоставляться различными организациями; включая образовательные учреждения, частные предприятия, неправительственные и общественные организации. В некоторых случаях, учреждения формального образования могут предоставлять неформальное образование и подготовку. Однако, как и в случае с программами формального образования, вид организации, предоставляющий образовательные услуги, не должен быть основным критерием для установления различий между неформальным образованием и подготовкой, а также для разграничения формального и неформального образования.

293. Продолжительность программ неформального образования может быть очень короткой. В особенности, подготовка (обучение) во время работы и отдыха может быть направлена на достижение конкретных практических целей, относящихся к конкретной работе или иметь частный жизненный контекст. Таким образом, программы неформального образования могут быть описаны как курс (подготовки).

294. Программы неформального образования редко направлены на приобретение практических знаний, навыков и компетенций в конкретном контексте и поэтому часто менее направлены на теоретическое обучение. Например, программа формального образования направлена на обучение компьютерным наукам (например, приобретение признанной квалификации в области информационных технологий в инженерном деле), в то время как программа неформального образования направлена на обучение применению специальных компьютерных программ в рабочих контекстах.

295. Альтернативные программы в основном существуют в странах, где система формального образования менее развита или охват ею образования ограничен. Эти программы не признаны как формальные органами образования; обычно эти программы охватывают уровни МСКО 0-3 и предоставляются частными организациями, включая неправительственные организации.

296. В то время как неформальное образование является признанной частью МСКО, вероятно, что сбор данных на международном уровне (классификация, опросы, переписи) будет ограничен охватом программ формального образования для обеспечения сопоставимости данных на международном уровне и реальности их сбора. Поэтому граница между программами формального и неформального образования важна, и ей должно быть уделено особое внимание. Однако, на этом этапе, МСКО 2011 не дает конкретной рекомендации о разработке классификации для программ неформального образования или соответствующих квалификаций в рамках неформального образования. 
Вторая или последующая степень. Степень, полученная в результате успешного завершения образовательной программы уровней МСКО 6 или 7, требующая предварительного успешного завершения программы на уровнях МСКО 6 или 7 для поступления с целью обучения по соответствующей образовательной программе.

Второй этап среднего образования (уровень МСКО 3). Программы уровня МСКО 3, или «второй этап среднего образования», как правило, рассчитаны на завершение среднего образования, дающего подготовку к третичному образованию или формирование навыков, позволяющих найти работу, или и то и другое. Программы этого уровня предлагают учащимся более разнообразное, специализированное и углубленное изучение предметов, чем программы второго этапа среднего образования (уровень МСКО 2). Они более дифференцированы и предоставляют более широкий выбор возможностей и направлений.

Выпуск. Успешное завершение образовательной программы. Выпускник может иметь несколько выпусков (даже в рамках одного и того же учебного года), если он одновременно обучался на двух и более программах и успешно завершил их.

Выпускник образовательной программы. Индивидуум, который успешно закончил образовательную программу.

Завершение образовательной программы. Участие во всех составных частях образовательной программы (включая выпускные экзамены, если таковые имеются) безотносительно результатов возможной оценки достижения целей обучения.

Завершение уровня МСКО. Успешное завершение образовательной программы, достаточное для завершения уровня. Для уровней МСКО 1 и 4-8 успешное завершение программы, соответствующее критериям содержания и минимальной продолжительности данного уровня, считается завершением уровня. Для уровней МСКО 2 и 3 успешное завершение любой программы, предоставляющее доступ к программам более высоких уровней МСКО (т.е. уровню МСКО 3 в случае программы уровня МСКО 2 и уровня MCKO 5, 6 и 7 в случае программы уровня MCKO 3), считается как завершением уровня, так и завершением любой конечной программы, соответствующей критериям содержания, минимальной продолжительности (2 года) и совокупной продолжительности соответствующего уровня МСКО (т.е. 8 лет с начала обучения на уровне МСКО 1 в случае программ уровня МСКО 2 и 11 лет в случае программ уровня МСKO 3).

Информальное обучение. Формы обучения, которые являются целенаправленными или тщательно спланированными, но не институционализированными. Следовательно, они менее организованные и структурированные, чем формальное или неформальное образование. Информальное обучение может включать учебную деятельность в семье, на рабочем месте, по месту жительства и в повседневной жизни, и направленность его определяется самостоятельно, семьей или социумом.

Квалификация. Официальное подтверждение, обычно документом, успешного завершения образовательной программы или этапа программы. Квалификации могут быть получены в результате: i) успешного завершения образовательной программы полностью; ii) успешного завершения этапа образовательной программы (промежуточные квалификации); или іiі) проверки приобретенных знаний, навыков и компетенций, вне зависимости от участия в образовательной программе. Это определение также может относиться к «ученой степени».

Класс. Конкретный этап обучения в рамках первоначального образования, обычно охватывающий учебный год. Возраст учащихся одного и того же класса обычно одинаков. Это определение также относится к понятиям «когорта» и «год». 
Кредит. Единица, предполагающая успешное завершение курсов или модулей и его документальное подтверждение в течение или в конце образовательной программы. Кредиты выражают объем обучения, который основан на нагрузке учащегося, необходимой для достижения целей обучения.

Курс. Единица обучения, подразумевающая последовательность в рамках образовательной деятельности в определенной области или ряде областей образования. Определение также можно отнести к понятиям «модуль», «раздел» или «предмет».

Минимальная продолжительность. Минимальная теоретическая продолжительность образовательной программы для классификации программ на определенном уровне МСКО или определения уровня завершения или неполного завершения на определенном уровне МСКО.

Модуль. Курс или часть курса в контексте модульной программы. Обучение может проходить в рамках одного модуля или сочетания предлагаемых модулей.

Модульные программы. Образовательные программы, которые позволяют учащимся гибко составлять содержание образования за счет сочетания различных курсов или модулей. Модульная программа, поэтому, часто не имеет четко установленной последовательности.

Начальное образование (уровень МСКО 1) предполагает учебную и образовательную деятельность, как правило, направленную на обучение основным навыкам чтения, письма и математики (т.е. грамотность и счет), и на создание серьезной основы для изучения и понимания основных областей знаний, для развития личности, для подготовки к обучению на первом этапе среднего образования. Начальное образование направлено на обучение на базовом уровне сложности с небольшой специализацией, если таковая имеется.

Неполное завершение уровня МСКО 2. Успешное завершение программы, продолжительностью не менее 2 лет на уровне МСКО 2 и совокупной продолжительности не менее 8 лет с начала обучения на уровне MCKO 1, и которые являются частью последовательности программ уровня МСКО 2, но не являются последними в последовательности на этом уровне. Эти программы не предоставляют прямого доступа к уровню МСКО 3.

Неполное завершение уровня МСКО 3. Успешное завершение программы, продолжительностью не менее 2 лет на уровне МСКО 3 и совокупной продолжительности не менее 11 лет с начала обучения на уровне МСКО 1, и которые являются частью последовательности программ уровня МСКО 3, но не являются последними в последовательности на этом уровне. Эти программы не предоставляют прямого доступа к более высокому уровню МСКО.

Несистемное обучение. Смотрите определения случайного или несистемного обучения.

Неуспешное завершение образовательной программы. Неспособность достичь учебных целей образовательной программы, несмотря на посещение или участие во всех компонентах образовательной программы (включая выпускные экзамены, если таковые существуют). Неуспешное завершение предполагает, что была оценка достижений целей обучения, но уровень продемонстрированных знаний, навыков и компетенций оценен как недостаточный.

Неформальная (образовательная) квалификация. Квалификация, присвоенная в результате достижения целей обучения образовательной программы в системе неформального образования, которая не признается соответствующими национальными образовательными властями и является эквивалентом квалификации в системе формального образования. 
Неформальное образование. Образование, которое институционализировано, целенаправленно и спланировано лицом или организацией, обеспечивающей предоставление образовательных услуг. Определяющей характеристикой неформального образования является то, что оно является дополнением и/или альтернативой формального образования в обучении в течение всей жизни индивидуума. Обучение в рамках таких программ часто ведется для обеспечения всеобщего права доступа к образованию. Неформальное образование доступно людям всех возрастов, но оно не обязательно имеет направленную структуру; оно может быть кратким по продолжительности и/или низким по интенсивности; и оно, как правило, организуется в форме краткосрочных курсов, мастерклассов или семинаров. Неформальное образование чаще всего ведет к получению квалификаций, которые не признаются квалификациями формального образования или эквивалентами формального образования соответствующими национальными или субнациональными органами образования, либо квалификации совсем не присваиваются. Неформальное образование может охватывать программы по ликвидации неграмотности взрослых и молодежи и программы для детей, не посещающих школу, а также программы по развитию жизненных и трудовых навыков, программы, направленные на социальное и культурное развитие.

Ниже начального образования (МСКО-У уровень 0). Обширный уровень образованности, охватывающий неучастие в образовательном процессе, некоторую степень участия в программах образования детей младшего возраста и/или некоторую степень участия в начальном образовании.

Область образования. Широкое понятие, раздел или область содержания в рамках образовательной программы, курса или модуля. Часто называется «предметом» или «дисциплиной». Также может называться «областями изучения».

Образование. Процессы, посредством которых общество целенаправленно передает накопленные знания, понимание, мироощущения, ценности, навыки, компетенции и модели поведение из поколения в поколение. Этот процесс включает коммуникацию с целью обучения.

Образование без отрыва от производства. Образовательная деятельность, которая проходит в рабочей обстановке, обычно в контексте программ профессионально-технического образования. Основной целью является достижение конкретных целей обучения, практическое обучение и участие в трудовой деятельности под руководством опытных работников или наставников.

Образование детей младшего возраста (МСКО-П уровень 0). Образование детей младшего возраста предполагает учебную и образовательную деятельность на основе комплексного подхода для поддержания познавательного, физического, социального и эмоционального развития детей младшего возраста, а также для знакомства детей младшего возраста с организованным обучением в отрыве от семейной обстановки с целью развития навыков, необходимых для подготовки к учебной деятельности и к поступлению на обучение по программам начального образования.

Образование для взрослых. Образование, главным образом направленное на тех, кто считается взрослыми в обществе, для совершенствования технических и профессиональных квалификаций, дальнейшего развития способностей, обогащения знаниями с целью завершения уровня формального образования, или для приобретения или обновления своих знаний, навыков и компетенций в какойлибо конкретной области. Образование для взрослых также может относиться к «непрерывному образованию», «возобновляемому образованию» или к «образовательным программам «второго шанса».

Образование для учащихся с особыми потребностями. Образование направлено на тех, кто по различным причинам, требует дополнительной поддержки и применения адаптированных педагогических методов работы с ними для участия в образовательных программах и достижения целей обучения. Причины могут быть следующими (но не ограничиваются этим списком): физические и 
умственные недостатки, проблемы поведенческого характера, проблемы развития эмоциональной сферы и проблемы социального характера. Образовательные программы для детей с особыми потребностями построены по учебному плану, аналогичному учебному плану в рамках обычного образования, однако, учитываются индивидуальные потребности обучающихся при обеспечении ресурсами (например, специально подготовленный персонал, оборудование или пространство) и, если необходимо, скорректированными содержанием образования и целями обучения. Эти программы могут предлагаться отдельным учащимся в рамках уже существующих образовательных программ, или обучении может проводиться в форме отельного занятия в тех же или других образовательных учреждениях.

Образование на базе школы или колледжа. Образовательная деятельность, осуществляемая в заведениях, предназначенных для образования детей и молодежи в рамках программ первоначального образования, которые направлены на достижение конкретных целей обучения, включая курсы, организованные в особой учебной среде (например, в лаборатории, кабинете музыки, компьютерном классе или спортивном зале), и проходят в группах под руководством одного или нескольких преподавателей. Учащиеся обычно сгруппированы по классу обучения, возрасту или уровню способностей.

Образовательная деятельность. Целенаправленная деятельность, включающая некоторую форму коммуникации, направленную на обучение.

Образовательная программа. Единый комплекс или последовательность образовательных мероприятий, спланированных и организованных для достижения заранее поставленных целей обучения или конкретных образовательных задач в течение непрерывного (продолжительного) периода времени. В рамках образовательной программы образовательная деятельность может быть сгруппирована по подкомпонентам, которые в различных национальных контекстах описываются как «курсы», «модули», «разделы» и/или «предметы». Программа может включать важные составные части, которые обычно не считаются курсами, разделами или модулями - например, деятельность на основе игр, практические занятия, научно-исследовательские проекты, подготовку диссертации.

Образовательные программы «второго шанса». Образование в особенности направлено на тех, кто в силу различных причин никогда не посещал или бросил школу до завершения уровня, в рамках которого они обучались, или завершил уровень, но желает обучаться по образовательной программе или получить профессию, поскольку еще не имеют соответствующей квалификации. Иногда это образование соотносится со «связующими программами» или «программами реинтеграции».

Обучение. Индивидуальное освоение, приобретение, усвоение или трансформация информации, знаний, понимания, мироощущений, ценностей, навыков, компетенций и поведения через инструкции, изучение, опыт и практику.

Общее образование. Образовательные программы, направленные на расширение общих знаний, навыков и компетенций учащихся, а также на развитие навыков чтения, письма и счета, часто для их подготовки к обучению по более продвинутым программам того же или более высоких уровней МСКО и на формирование основы для обучения на протяжении всей жизни индивидуума. Программы общего образования обычно проводятся на базе школы или колледжа. Общее образование включает образовательные программы, разработанные для подготовки учащихся к поступлению на программы профессионально-технического образования, но не направленные на подготовку к трудоустройству по определенному виду или видам профессий и на непосредственное получение востребованной на рынке труда квалификации.

Обычная продолжительность. Время в пересчете на учебные года, обычно требуемое учащимся для успешного завершения образовательной программы, предполагая обычное очное участие в программе. 
Обычное образование. Первоначальное образование для учащихся без особых образовательных потребностей.

Организация, обеспечивающая предоставление образовательных услуг. Организация, для которой предоставление образовательных услуг является основной или сопутствующей целью. Это может быть государственное учебное заведение, а также частное предприятие, негосударственная организация или государственная необразовательная организация.

Оценивание результатов обучения. Оценивание достижения целей обучения людей с помощью разнообразных методов (письменное, устное тестирование/экзамены, практические тесты, проект и портфолио) в течение или в конце образовательной программы.

Первая степень. Степень, полученная в результате успешного завершения образовательной программы на уровнях МСКО 6 и 7, не требующая предварительного успешного получения любой степени уровня МСКО 6 для поступления с целью обучения по соответствующей образовательной программе.

Первоначальное образование. Первоначальное образование людей до их первого выхода на рынок труда, т.е. до того, как они будут получать формальное образование в очной форме. Оно, таким образом, направлено на тех, кто считается обществом, детьми, подростками и молодыми людьми. Как правило, обучение в рамках этого образования имеет место быть в учебных заведениях, обеспечивающих его непрерывность.

Первый этап среднего образования (уровень МСKO 2). Программы уровня MCKO 2, или программы «первого этапа среднего образования», как правило, основываются на учебных результатах уровня МСКО 1. Обычно цель образования заключается в том, чтобы заложить основы для обучения в течение всей жизни индивидуума и для развития личности, что может позволить образовательным системам расширять возможности для дальнейшего получения образования. Программы этого уровня обычно организованы по учебному плану, ориентированному на конкретные предметы с объяснением теоретических понятий по широкому кругу вопросов.

Подготовка. Образование для достижения конкретных целей обучения, особенно в профессиональнотехническом образовании. Определение «образования» в МСКО также включает понятие «подготовка».

Последующая степень. См. вторая или последующая степень.

Послесреднее нетретичное образование (уровень МСКО 4). Послесреднее нетретичное образование предполагает учебный опыт на основе среднего образования, подготавливая как к выходу на рынок труда, так и к получению третичного образования. Это образование, как правило, направлено на учащихся, завершивших второй этап среднего образования (уровень МСКО 3), но желающих повысить шансы на рынке труда или далее обучаться в системе третичного образования. Программы часто незначительно сложнее, чем программы второго этапа среднего образования, поскольку они служат, как правило, скорее для расширения, чем для углубления знаний, навыков и компетенций. Поэтому оно направлено на обучение на уровне ниже параметра высокого уровня сложности третичного образования.

Поступившие. Индивидуумы, зачисленные в начале образовательного уровня, ряда уровней, программы, или этапа программы, или ее модуля, вне зависимости от возраста.

Поступление. Начало участия в обучении на образовательном уровне, ряде уровней, программе, или этапе программы или ее модуле.

Признанная квалификация. Официальное подтверждение соответствующими национальными образовательными властями квалификации, полученной в результате достижения целей обучения образовательной программы со стороны. 
Проверка результатов обучения. Оценивание достижения целей обучения людьми с помощью разнообразных методов оценивания (письменное, устное тестирование/экзамены, практические тесты, проект и портфолио), не предполагающее участия в образовательной программе.

Программы дуальной системы образования. Программы, объединяющие образование на базе школы или колледжа, и программы без отрыва от производства. Обе составные части значимы (т.е. выходят за пределы отдельной интернатуры или нерегулярных занятий), хотя образование без отрыва от производства обычно охватывает 50\% времени программы или более.

Промежуточная квалификация образования. Официальное подтверждение, обычно документом, удостоверяющим успешное завершение этапа образовательной программы.

Профессионально-техническое образование. Образовательные программы, направленные на приобретение знаний, навыков и компетенций для занятий определенного вида или видам профессиональной деятельности. Профессионально-техническое образование может включать такие компоненты, как обучение на базе предприятий (например, стажировка, дуальные образовательные программы). Успешное завершение таких программ ведет к получению пользующихся спросом на рынке труда профессиональных квалификаций, которые признаются соответствующими национальными властями и/или рынком труда как профессионально-ориентированные.

Случайное или несистемное обучение. Формы обучения, которые не являются организованными и предполагают коммуникацию, не предназначенную для обучения. Случайное или несистемное обучение может стать побочным продуктом повседневной деятельности или мероприятий или коммуникации, не предназначенных для целенаправленного образования или учебной деятельности. Примерами подобного обучения может быть общение при встрече, радио- и телепередачи, не являющиеся образовательными программами.

Совокупная продолжительность. Общая теоретическая продолжительность последовательности образовательных программ. В МСKO, с начала уровней МСКО 1 и 3 или с начала обучения на программах третичного образования, понятие «совокупной продолжительности» необходимо для классификации образовательной программы.

Среднее образование (уровни МСКО 2 и 3). Среднее образование предоставляет учебную и образовательную деятельность, базирующуюся на начальном образовании и готовящую как к выходу на рынок труда, так и ко второму этапу послесреднего нетретичного образования и третичному образованию. В целом, среднее образование направлено на обучение на среднем уровне сложности. В МСКО проводится различие между первым и вторым этапом среднего образования.

Степень. Образовательная квалификация, полученная в результате успешного завершения отдельных образовательных программ третичного образования (традиционно в университетах или равнозначных им учебных заведениях).

Теоретическая продолжительность. Время в пересчете на учебные года, требуемое для реализации образовательной программы, предполагая обычное очное участие в программе.

Третичное образование (уровни МСКО с 5 по 8). Третичное образование основывается на среднем образовании, организуя учебную деятельность в рамках специализированных областей образования. Оно направлено на обучение на более высоком уровне сложности и специализации. Третичное образование включает то, что обычно понимается как академическое образование, но оно также включает профессиональное образование. 
Уровень полученного образования. Самый высокий уровень МСКО, успешно завершенный индивидуумом. Он обычно измеряется по отношению к самой высокой по уровню завершенной образовательной программе, которая, как правило, документально подтверждается признанной квалификацией. Признанная промежуточная квалификация относится к более низкому уровню, чем сама программа.

Уровни образования. Упорядоченный набор категорий, классифицирующий образовательные программы в соответствии с градацией учебного опыта, а также навыков и компетенций, которые призвана дать образовательная программа. Уровень МСКО отражает степень сложности и специализации содержания образовательной программы, от основного до сложного.

Успешное завершение образовательной программы. Достижение учебных целей образовательной программы, как правило, подтверждаемое через оценку приобретенных знаний, умений и компетенций. Успешное завершение образовательной программы обычно сопровождается выдачей документа, подтверждающего образовательную квалификацию.

Участие. Посещение или обучение в рамках образовательной программы, этапа программы или ее модуля.

Участник. Индивидуум, который посещает или принимает участие в образовательной программе или этапе программы или ее модуле.

Учащиеся. Индивидуумы, официально зарегистрированные на данную образовательную программу, или этап программы, или ее модуль, вне зависимости от возраста.

Учебная деятельность. Целенаправленная деятельность, участники которой имеют намерение учиться.

Учебное заведение. Официальная организация (школа, колледж, университет или учебный центр), основной целью которой является предоставление образования. Такие организации обычно аккредитуются и получают официальное разрешение на деятельность от национальных властей или равнозначных им органов. Частные организации, такие как религиозные, частные образовательные заведения, учебные предприятия, как коммерческие, так и некоммерческие, также могут организовывать деятельность учебных заведений.

Учебные результаты. Совокупность информации, знаний, понимания, мироощущений, ценностей, компетенций и моделей поведения, которыми, как ожидается, должен владеть слушатель в результате успешного завершения образовательной программы.

Учебный год. Ежегодный учебный или экзаменационный период, в течение которого учащиеся посещают курсы или сдают выпускные экзамены, небольшие перерывы не учитываются. Этот период может быть менее 12 месяцев, но, как правило, не короче 9 месяцев. Продолжительность может быть различной на разных уровнях образования или в разных учебных заведениях страны. Определение также относится к понятию «школьный год», главным образом для уровня дотретичного образования.

Формальное образование. Образование, которое является институционализированным, целенаправленным и спланированным при участии государственных организаций и признанных государством частных организаций, что в совокупности составляет систему формального образования страны. Таким образом, программы формального образования признаются как таковые соответствующими национальными властями или равнозначными им организациями, например, любым учебным заведением в сотрудничестве с национальными и субнациональными органами образования. Формальное образование, в основном, состоит из программ предварительного образования. Профессионально-техническое образование, образование для учащихся с особыми потребностями и некоторые компоненты образования для взрослых зачастую рассматриваются как часть системы формального образования. 
Цели обучения. Спецификация учебных результатов, которых необходимо достичь по завершении образовательной или учебной деятельности. Они состоят в усовершенствовании знаний, навыков и компетенций в областях, относящихся к личной, гражданской, социальной и производственной деятельности. Как правило, цели обучения связаны с подготовкой к обучению на более высоком уровне и/или работе в одной или нескольких областях.

Этап. Подуровень образовательной программы, рассматриваемый в рамках теоретической продолжительности или определенного набора модулей для завершения программы или накопления кредитов. Отдельный этап имеет характеристики, отличные от других этапов одной и той же образовательной программы и по окончании этапа может выдаваться документ о получении промежуточной квалификации. 
Поскольку системы образования разных стран разнообразны по своей структуре и содержанию, Международная стандартная классификация образования (МСКО) обеспечивает основу для представления данных в сопоставимом и унифицированном формате. Она упрощает процесс преобразования данных о национальных системах образования в согласованные на международном уровне категории, которые позволяют проводить сравнения на межнациональном уровне.

МСКО - это базовая классификация, входящая в Международную систему экономических и социальных классификаций Организации Объединенных Наций. Впервые разработанная ЮНЕСКО в 1970-х годах, она периодически обновлялась для того, чтобы отражать непрерывную эволюцию систем образования по всему миру. В новой МСКО 2011 (пришедшей на замену МСКО 1997) представлены усовершенствованные определения и более обширный материал, которые позволяют успешнее отслеживать мировые образовательные модели. Так, существенному пересмотру подверглись разделы, посвящённые третичному образованию и образованию детей младшего возраста. Кроме того, в МСКО 2011 представлены новые схемы кодирования образовательных программ и уровней полученного образования.

Куратором МСКО, ответственным за разработку, поддержание, обновление и пересмотр классификации, является Институт статистики ЮНЕСКО (ИСЮ). Он обеспечивает руководство по эффективному и последовательному использованию МСКО для сбора и анализа данных на международном уровне.

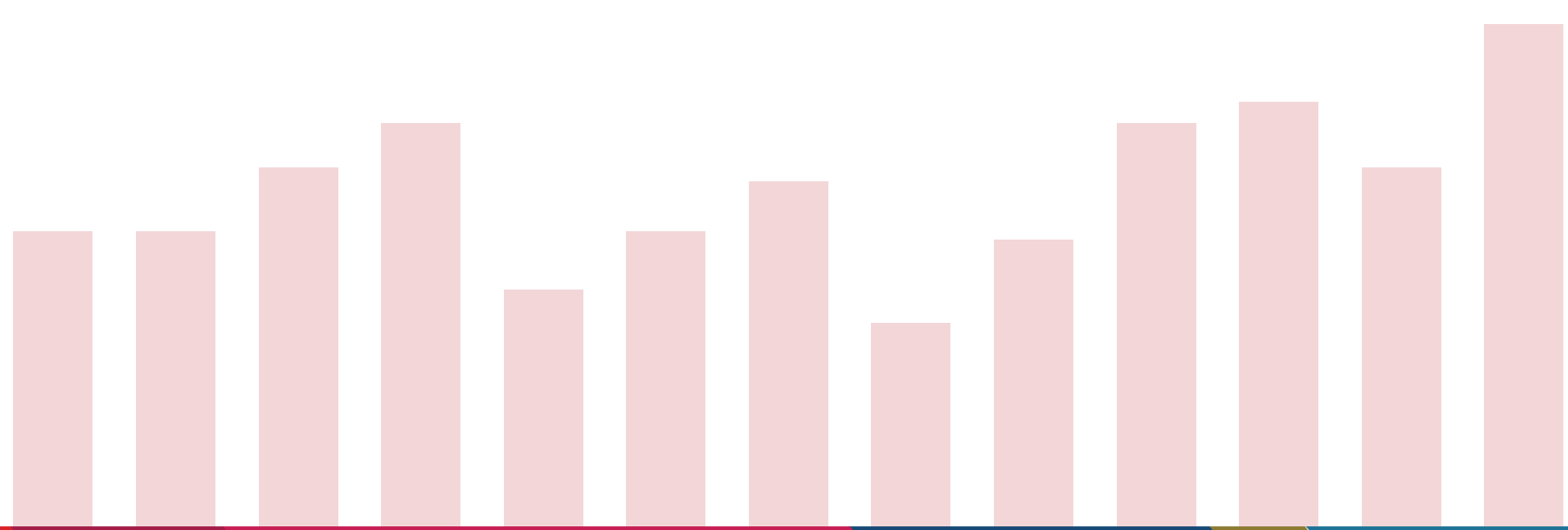

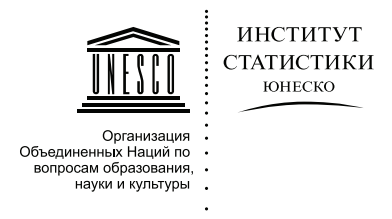

Институт Статистики ЮНЕСКО (ИСЮ) является статистическим органом Организации 0бъединенных Наций по вопросам образования, науки и культуры (ЮНЕСКО). ИСЮ является хранилищем сопоставимых на международном уровне статистических данных в области образования, науки и техники. 